\title{
CERATIUM SCHRANK (DINOPHYCEAE) OF THE NATIONAL PARK SISTEMA ARRECIFAL VERACRUZANO, GULF OF MEXICO, WITH A KEY FOR IDENTIFICATION
}

\author{
YURI B. ОKOLODKOV \\ Universidad Veracruzana, Instituto de Ciencias Marinas y Pesquerías, Calle \\ Hidalgo núm. 617, Colonia Río Jamapa, Boca del Río, 94290 Veracruz, México. \\ yuriokolodkov@yahoo.com
}

\begin{abstract}
The morphology of 33 species of Ceratium (38 including infraspecific taxa) was studied based on about 600 phytoplankton 20- $\mu$ m net samples taken from May 2005 through March 2008 at eight sampling stations in the northwestern part of the National Park Sistema Arrecifal Veracruzano, southern Gulf of Mexico. Short descriptions and synonyms are given for each species. Cell size variation with the mean and the standard deviation are given for most species. Twenty-three species are provided with affinities and taxonomic, nomenclatural or biogeographic comments. A dichotomous key for identification of all the species found is presented, and species are illustrated with light microscope photographs and line drawings. Ceratium dens, C. bigelowii, C. limulus, C. tripos f. tripodoides and C. declinatum var. angusticornum are new records for the Mexican waters of the Gulf of Mexico.
\end{abstract}

Key words: Ceratium, dinoflagellates, Gulf of Mexico, key for identification, taxonomy.

\section{RESUMEN}

Se estudió la morfología de 33 especies de Ceratium (38 incluso los taxa infraespecíficos) con base en aproximadamente 600 muestras de red $(20 \mu \mathrm{m})$ tomadas de mayo de 2005 a marzo de 2008 en ocho estaciones de muestreo en el sector noroeste del Parque Nacional Sistema Arrecifal Veracruzano, la parte sur del Golfo de México. Para cada especie se dan descripciones cortas, así como la sinonimia. La variación de tamaño 
de las células, el promedio y la desviación estándar se presentan para la mayoría de las especies. Para 23 taxa se proporcionan notas sobre sus afinidades, al igual que comentarios taxonómicos, nomenclaturales y biogeográficos. Se incluye una clave dicotómica para la identificación, así como las fotografías en microscopio fotónico y dibujos a línea de todas las especies encontradas. Ceratium dens, C. bigelowii, C. limulus, C. tripos f. tripodoides y C. declinatum var. angusticornum son nuevos registros para la parte mexicana del Golfo de México.

Palabras clave: Ceratium, clave para identificación, dinoflagelados, Golfo de México, taxonomía.

\section{INTRODUCTION}

The genus Ceratium is one of the most common and widespread in marine phytoplankton, along with the genus Protoperidinium Bergh. In the southern Gulf of Mexico, 13 of the 28 most common dinoflagellate species belong to the genus $\mathrm{Ce}$ ratium (Licea et al., 2004). Similarly, in the northern Gulf of Mexico, 13 Ceratium species were among the 30 most common (Balech, 1967). Due to the larger cell size of Ceratium species and their relatively well-known latitudinal geographic distributions, in many cases rather well delimited (Dodge, 1993; Dodge \& Marshall, 1994), they have been used as biological indicators of water masses and currents (Frost \& Wilson, 1938; Graham, 1941; Okolodkov, 1996). Ceratium has been suggested as an excellent, if not the best, dinoflagellate genus to use for biogeographic study and as a tool for defining ocean currents and temperature ranges and may be valuable in studies of global change (Dodge \& Marshall, 1994). In the Gulf of Mexico, $70 \mathrm{Ce}$ ratium species ( 97 together with infraspecific taxa) have been recorded (Steidinger et al., 2009).

The taxonomy of Ceratium has remained extraordinarily stable since the end of the 19th century in spite of many important contributions to the morphology and systematics of this genus. Most Ceratium species have three horns; some have two. Recently a species with only one horn, the apical one, was described from a lake (Temponeras et al., 2000). Sournia (1986) clearly indicated the difference between freshwater and marine species based on the number of cingular plates. However, using genetic molecular analysis the genus was split into two, and a new genus designated as Neoceratium F. Gómez, D. Moreira et P. López-García for all known marine species (Gómez et al., 2010) was proposed. Traditionally, identification of 
species and infraspecific taxa within this genus is based on the shape of the cell and its parts (mainly antapical horns) in ventral or dorsal view and some other features of the theca usually shared by a group of species. This is the approach followed here in describing species belonging to the genus Ceratium according to Sournia (1986).

In the State of Veracruz some Ceratium species have been reported (OchoaFigueroa, 1978; Avendaño-Sánchez \& Sotomayor Navarro, 1982; Echeverría-Valencia, 1983; Hernández-Mendiola, 1988; Suchil-Vilchis, 1990; Guerra-Martínez \& Lara-Villa, 1996; Zamudio-Resendiz, 1998; Aquino-Cruz, 2002; García-Reséndiz, 2003; Legaría-Moreno, 2003; Estradas-Romero, 2004; Tejeda-Hernández, 2005). Zamudio-Resendiz (1998) mentioned 22 Ceratium species; however, she did not give separate species lists for the State of Tamaulipas and the State of Veracruz. Nevertheless, her data are considered in the present article as all them were for Veracruz. The only study (an MSc thesis) focused on the genus Ceratium in both Veracruz waters and the southern Gulf of Mexico was by Figueroa-Torres (1990). It includes numerous line drawings and photographs of 35 Ceratium species and infraspecific taxa found during three oceanographic cruises encompassing a month in general (18¹5'-1949' N, 9339'-9548' W).

To document Ceratium species found in the National Park Sistema Arrecifal Veracruzano (NPSAV) and to provide a key for their identification were the goals of the present study.

\section{MATERIAL AND METHODS}

Phytoplankton samples were taken weekly with a hand net, $20 \mu \mathrm{m}$ mesh and $30 \mathrm{~cm}$ mouth, from eight sites (stations) around the Aquarium of Veracruz in the northwestern part of the National Park Sistema Arrecifal Veracruzano. Collections were made during the period from May 2005 through March 2008 as part of the monitoring program of the Aquarium of Veracruz (Fig. 1, Table 1). Some material was taken and examined from two additional stations sampled in NovemberDecember 2007 and in March 2008 (1902'48.1" N, 95²49'25.4" W; 19¹0'26.9" $\left.\mathrm{N}, 96^{\circ} 01^{\prime} 1.3^{\prime \prime} \mathrm{W}\right)$. At each station the net was towed horizontally for $5 \mathrm{~min}$. at the velocity of the boat of ca. 2.5 knots to sample a superficial $30-\mathrm{cm}$ layer. The samples were fixed with a stock formaldehyde solution to a final concentration of $4 \%$ and stored in 100-ml dark plastic bottles. To contrast the cells for an easier search and better photographs, a $0.2 \%$ Trypan Blue water solution was added to water mounts (Lebour, 1925; Taylor, 1978). About 600 samples were analyzed using a Nikon 


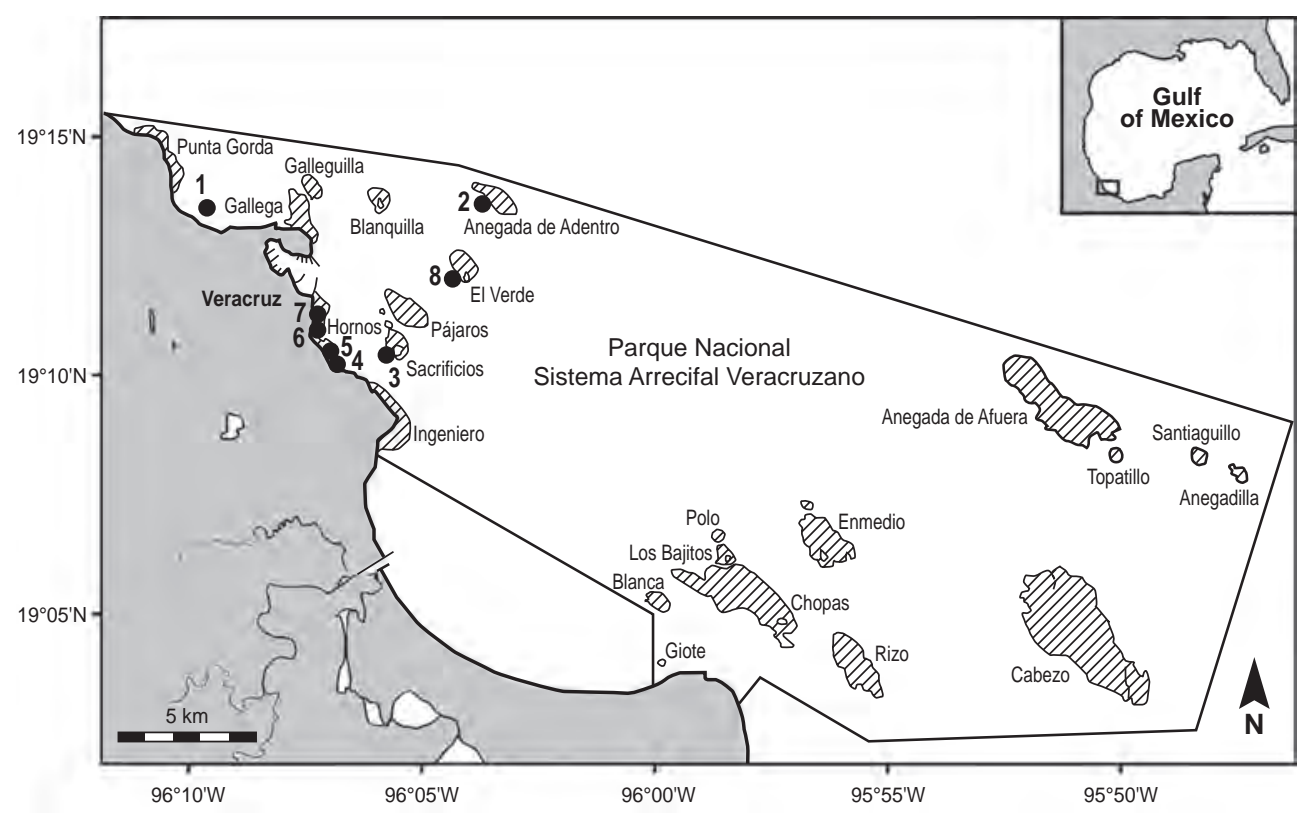

Fig. 1. Sampling sites in the National Park Sistema Arrecifal Veracruzano. Filled circles indicate locations where planktonic dinoflagellates were sampled. Hatched areas are coral reefs.

Table 1. Sampling sites (stations) in the National Park Sistema Arrecifal Veracruzano, Veracruz, Gulf of Mexico, May 2005 - March 2008.

\begin{tabular}{|c|c|c|}
\hline Station & Location & Geographic coordinates \\
\hline 1 & Playa Norte - Planta de residuos & $19^{\circ} 13^{\prime} 06.0^{\prime \prime} \mathrm{N}, 9^{\circ} 09^{\prime} 34.5^{\prime \prime} \mathrm{W}$ \\
\hline 2 & Arrecife Anegada de Adentro & $19^{\circ} 13^{\prime} 41.1^{\prime \prime} \mathrm{N}, 9^{\circ} 03^{\prime} 44.4^{\prime \prime} \mathrm{W}$ \\
\hline 3 & Arrecife Isla de Sacrificios & $19^{\circ} 10^{\prime} 32.7^{\prime \prime} \mathrm{N}, 9^{\circ} 05^{\prime} 40.9^{\prime \prime} \mathrm{W}$ \\
\hline 4 & Hotel "Lois" & $19^{\circ} 10^{\prime} 27.1^{\prime \prime} \mathrm{N}, 9^{\circ} 06^{\prime} 51.3^{\prime \prime} \mathrm{W}$ \\
\hline 5 & Asta Bandera & $19^{\circ} 10^{\prime} 37.4^{\prime \prime} \mathrm{N}, 96^{\circ} 07^{\prime} 10.9^{\prime \prime} \mathrm{W}$ \\
\hline 6 & Hotel "Villa del Mar” & $19^{\circ} 11^{\prime} 04.6^{\prime \prime} \mathrm{N}, 96^{\circ} 07^{\prime} 20.6^{\prime \prime} \mathrm{W}$ \\
\hline 7 & Acuario - Escuela Náutica & $19^{\circ} 11^{\prime} 15.2^{\prime \prime} \mathrm{N}, 9^{\circ} 07^{\prime} 19.4^{\prime \prime} \mathrm{W}$ \\
\hline 8 & Isla Verde & $19^{\circ} 12^{\prime} 12.2^{\prime \prime} \mathrm{N}, 9^{\circ} 04^{\prime} 00.1^{\prime \prime} \mathrm{W}$ \\
\hline
\end{tabular}


TS100 and an Olympus CKX41 inverted microscope for a Sedgwick-Rafter 1-ml chamber and an Olympus BX51 compound microscope for water mounts. The cells were photographed mainly with an Olympus C7070 digital camera. Line drawings were made from digital images.

About 90 publications, abstracts and theses on the phytoplankton and dinoflagellates of the Gulf of Mexico were examined, with special emphasis on the state of Veracruz. Extensive old and new literature containing illustrations were analyzed and cited. The works where the species are illustrated are marked with asterisks: an asterisk (*) indicates line drawings, two asterisks $(* *)$ indicate light micrographs, and three asterisks (***) indicate scanning electron micrographs. The cited literature is referred to a species in general, not to a given infraspecific taxon. Relative abundance was given according to the following criteria: extremely rare - found in $<1 \%$ of the analyzed samples only occasionally (less than 25 cells were found in total), rare - encountered in 1 to $10 \%$ of the samples as rare cells, common - seen in 11 to $50 \%$ of the samples (normally as dozens of cells in a Sedgwick-Rafter chamber), and very common - found in $>50 \%$ of the samples (dozens or hundreds of cells per chamber).

The abbreviations for cell measurements are as follows: $\mathrm{L}$ - total length measured from the furthest part of the hypotheca including the antapical horns; $\mathrm{Wb}$ - cell body
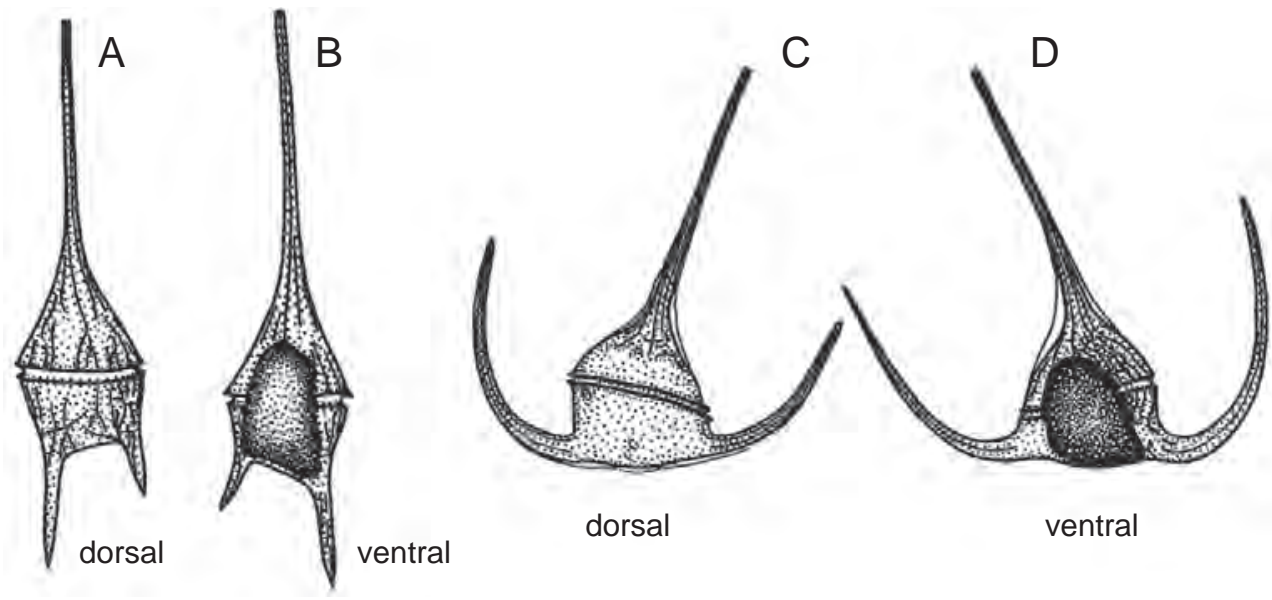

Fig. 2. Line drawings of two morphological cell types in the genus Ceratium in dorsal and ventral views: A and B - subgenera Amphiceratium and Ceratium, C and D - subgenus Tripoceratium; the apical horn and the anterior part of the cell are situated above in each drawing (after Wiktor \& Okolodkov, 1995). 
width measured in ventral or dorsal view just in front of or behind the cingulum, not considering the precingular or postcingular membranes (the only measured width in the species with straight or slightly curved antapical horns directed backward; always measured using the 40x objective to avoid a large error); Wt - total width, considering the distance between external sides of the antapical horns directed laterally, forward or laterally-forward. Cells were measured in dorsal (DV) or ventral view (VV); to facilitate identification, drawings of two morphological cell types in both views are given in Fig. 2. Recently divided cells with undeveloped horns ( $\mathrm{Pl}$. 8, Fig. 1-8), teratologic forms (Pl. 7, Fig. 2) and microgametes (Pl. 7, Fig. 3) were avoided during measurements.

\section{RESULTS}

Key for identification of species of the genus Ceratium

1a Cells with 1 or 2 antapical horns directed posteriorly (subgenera Amphiceratium and Ceratium)

1b Cells with 2 antapical horns directed anteriorly (subgenus Tripoceratium) ..... 10

2a Cells long or very long, spindle-shaped or needle-shaped, cell body not differentiated or weakly differentiated from the apical horn, with 1 very long antapical horn, another one may be absent or strongly reduced (subgenus Amphiceratium) ...

$2 \mathrm{~b}$ Cells rather short or sometimes very long, cell body well differentiated from the apical horn (with some exceptions), with 2 well developed antapical horns (subgenus Ceratium)

3a Cells with epitheca and hypotheca equal or subequal in length 4

3b Cells with hypotheca much longer (about 1.5-2.0 times) than epitheca

(1) C. extensum

4a Cells generally less than $500 \mu \mathrm{m}$ long, with slightly curved horns ...................... 5

$4 \mathrm{~b}$ Cells longer than $500 \mu \mathrm{m}$, with notably curved left antapical horn 7

5a Cell body occupies about one-third of the total length, constricted in the proximal part of the epitheca (2) C. geniculatum 
$5 \mathrm{~b}$ Cell body occupies less than a quarter of the total length, without a constriction in the epitheca

6a Cell body strongly inflated, subovoid (3) C. bigelowii

$6 \mathrm{~b}$ Cell body slightly inflated, fusiform (4) C. fusus

7a Cell body more or less clearly differentiated from the apical horn

(5) C. inflatum

$7 \mathrm{~b}$ Cell body not differentiated or weakly differentiated from the apical horn ....... 8

8a Hypotheca about one-half of the epitheca in length (6) C. belone

$8 \mathrm{~b}$ Hypotheca and epitheca equal or subequal in length

(7) C. longirostrum

9a Cell body about twice as wide as long, with the apical horn emerging eccentrically

(8) C. candelabrum

9b Cell body slightly longer than wide or as long as wide, with the apical horn emerging centrically 10

10a Cell body poorly differentiated from the apical horn (9) C. furca 10b Cell body well differentiated from the apical horn 11

11a Cell body as long as wide, almost regularly pentagonal, $>50 \mu \mathrm{m}$ wide (10) C. pentagonum

11b Cell body slightly longer than wide, $<50 \mu \mathrm{m}$ wide 12

12a Cells with slightly convex sides, $>30 \mu \mathrm{m}$ wide, with very short antapical horns and poorly distinguished cingulum (11) C. teres

$12 \mathrm{~b}$ Cells with straight sides, $<26 \mu \mathrm{m}$ wide, with relatively longer antapical horns and well distinguished cingulum

(12) C. kofoidii

13a Cell body covered with coarse reticulations or ridges (13) C. hexacanthum $13 \mathrm{~b}$ Cells not covered with coarse reticulations or ridges 14

14a Right antapical horn about 3 to 4 times longer than left one (14) C. dens

14b Antapical horns more or less equal in length 15

15a Antapical horns terminated with finger-shaped appendages ...... (15) C. ranipes 
15b Antapical horns without finger-shaped appendages

16a Cell body subquadrangular or subpentagonal ..................................................... 17

16b Cell body subtriangular

17a Cell body subquadrangular, with "shoulders" at its proximal margin, making the apical horn well separated (16) C. limulus

17b Cell body subpentagonal, with a twisted right antapical horn, abruptly curved in the middle at an angle of $90^{\circ}$ (17) C. gibberum var. dispar

18a Theca strongly sculptured, posterior membrane and membranes on the horns well developed (18) C. vultur

18b Theca weakly or moderately sculptured, posterior membrane and membranes on the horns usually poorly developed 19

19a Hypotheca strongly or slightly rounded at the posterior end, leading directly into antapical horns, lacking a notch between the bases of the horns .............. 20

19b Hypotheca usually flat or slightly convex at the posterior end, with 1 or 2 antapical horns behind the furthest point of the cell body, frequently with a notch between the horns and between one horn and the cell body 28

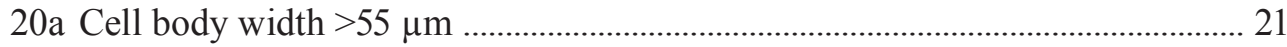

20b Cell body width $<55 \mu \mathrm{m}$........................................................................................ 24

21a Cell body almost triangular, with nearly flat sides of the epitheca, antapical horns are developed as well as the apical one (19) C. lunula

21b Cell body subtriangular, with markedly convex sides of the epitheca, antapical horns are less developed than the apical one 22

22a Right antapical horn twisted in a dorso-ventral plane, apical horn is directed anteriorly at its base and then bends to the right (20) C. contortum

22b Right antapical horn not twisted in a dorso-ventral plane, apical horn straight or nearly straight although inclined to the right (21) C. karstenii

23a Cell body with a posterior margin very oblique in relation to the cingulum (22) C. euarcuatum 
23b Cell body with a posterior margin slightly oblique, almost parallel in relation to the cingulum

24a Cell body width $>60 \mu \mathrm{m}$, with almost flat posterior margin (23) C. tripos

24b Cell body width $<60 \mu \mathrm{m}$, with markedly convex posterior margin 25

25a Cells $<100 \mu \mathrm{m}$ wide, right antapical horn is positioned very close to the cell body, antapical horns are very short (24) C. azoricum

$25 \mathrm{~b}$ Cells $>100 \mu \mathrm{m}$ wide, antapical horns are long and positioned far from the cell body at equal distance 26

26a Right antapical horn forms a semi-circle with its distal part directed to the left .. (25) C. arietinum var. gracilentum

26b Both antapical horns are directed anteriorly or anteriorly-laterally 27

27a Apical horn is positioned centrally (26) C. symetricum

27b Apical horn emerges from the left side of the cell body (27) C. declinatum

28a Cells $>800 \mu \mathrm{m}$ wide (28) C. carriense

28b Cells $<600 \mu \mathrm{m}$ wide 29

29a Bases of the antapical horns are directed posteriorly, forming a deep notch between them (29) C. macroceros var. gallicum

29b Bases of the antapical horns are directed laterally-posteriorly, forming a shallow notch between them 30

30a Cell length and width are normally $<250 \mu \mathrm{m}$ (30) C. horridum

$30 \mathrm{~b}$ Cell length and width are normally $>300 \mu \mathrm{m}$ 31

31a Cell body robust, subtriangular, posterior membrane well developed, a notch between the antapical horns is notable only near the right horn

(31) C. massiliense var. armatum

31b Cell body delicate, subtrapezoidal, posterior membrane poorly developed, a notch between the antapical horns is symmetrical in relation to them 32

32a Cells $>50 \mu \mathrm{m}$ long (32) C. contrarium

32b Cells $<50 \mu \mathrm{m}$ long (33) C. trichoceros 


\section{TAXONOMIC DESCRIPTIONS}

\section{Subgenus Amphiceratium Vanhöffen}

1. Ceratium extensum (Gourret) Cleve, 1900 (Pl. 1, Fig. 1 and 2; Pl. 10, Fig. 1) Bas.: Ceratium fusus var. extensum Gourret, 1883: 52, pl. 4, fig. 56. Syn.: Ceratium biceps Claparède et Lachmann, 1859: 400, pl. 19, fig. 8.

Cells spindle-shaped, long. Epitheca tapers into a long apical horn and hypotheca tapers into a long left antapical horn. Left antapical horn markedly (about 1.5 times or more) longer than apical one, both straight or nearly straight. A reduced right antapical horn may be present. Widest point adjacent to the cingulum. L 815$1720 \mu \mathrm{m}(1253.1 \pm 215.3 \mu \mathrm{m}), \mathrm{Wb} 25-35 \mu \mathrm{m}(29.2 \pm 2.7 \mu \mathrm{m}) ; \mathrm{n}=21$.

Affinities: C. fusus, C. inflatum, C. longirostrum.

Records in the State of Veracruz: Figueroa-Torres, 1990* **; Suchil-Vilchis, 1990; Zamudio-Reséndiz, 1998. Rare to common in NPSAV (Feb., March, May, July, Aug., Nov., Dec.).

References: Jörgensen, 1911*: 28, fig. 50a; 1920*: 43, fig. 31; Lebour, 1925*: 146, fig. 463; Steemann Nielsen, 1934*: 14, fig. 24; Schiller, 1937*: 380, fig. 419a, b; Rampi, 1939*: 304, fig. 11; Graham \& Bronikovsky, 1944*: 24, fig. 11BB-DD; Kiselev, 1950*: 244, fig. 412; Silva, 1956*: 56, pl. 7, fig. 8 (f. strictum); Kato, 1957*: 14, pl. 4, fig. 10a-c; López, 1966*: fig. 12; Subrahmanyan, 1968*: 32, fig. 56, 57; Wood, 1968*: 28, fig. 54; Steidinger \& Williams, 1970**: 45, pl. 7, fig. 19; Hassan \& Saifu1lah, 1974*: 85, fig. 10; Taylor, 1976*: 64, pl. 13, fig. 127, 128 (as C. biceps Claparède et Lachmann, 1859); Pesantes-Santana, 1978*: 10. pl. 6, fig. 9; Tester \& Steidinger, 1979**: 28, pl. 10, fig. 61; Dowidar, 1983*: 12, pl. 2, fig. 5; Balech, 1988*: 133, pl. 55, fig. 1, 2; Konovalova et al., 1989*: 132, fig. 49(3); Licea et al., 1995*: 35, pl. 18, fig. 4; Konovalova, 1998*: 140, fig. 29(4).

2. Ceratium geniculatum (Lemmermann) Cleve, 1901 (Pl. 1, Fig. 3; Pl. 10, Fig. 2)

Bas.: Ceratium fusus var. geniculatum Lemmermann, 1899: 349, pl. 1, fig. 17.

Cells spindle-shaped, relatively long. The cell body is long, clearly constricted in the middle. Epitheca is inflated, in its distal part suddenly drawn into an apical horn and hypotheca tapers into a long left antapical horn, slightly curved. Apical horn positioned closer to the left side of the cell, notably deflected to the left at its 
base. A reduced right antapical horn is present. Widest point adjacent to the cingulum and also in front of the constriction in the middle of the cell body. L $310 \mu \mathrm{m}$, Wb $30 \mu \mathrm{m} ; \mathrm{n}=1$.

A new record for the State of Veracruz. Extremely rare in NPSAV (the only specimen observed was collected on 25 December 2005 relatively far from the shore at st. 2).

References: Karsten, 1907*: pl. 50, fig. 3a, b; Jörgensen, 1911*: 24, fig. 42, 43; 1920*: 34, fig. 24; Böhm, 1931b*: 43, fig. 37c, d; Steemann Nielsen, 1934*: 13, fig. 17; Schiller, 1937*: 375, fig. 414a; Graham \& Bronikovsky, 1944*: 22, fig. 11J; Wood, 1954*: 279, fig. 197; 1968*: 30, fig. 60; Sournia, 1968*: 407, fig. 30, 31; Subrahmanyan, 1968*: 28, fig. 43-45; Konovalova, 1998*: 137, fig. 28(9).

\section{Ceratium bigelowii Kof., 1907 (Pl. 1, Fig. 4 and 5; Pl. 10, Fig. 3)}

Cells spindle-shaped, long. Cell body is well distinguished, inflated, suboval. Epitheca tapers into a long apical horn and hypotheca tapers into a long left antapical horn. Apical and left antapical horns equal or subequal in length; apical horn slightly curved and the left antapical horn notably continuously curved. A reduced right antapical horn may be present. Widest point adjacent to the cingulum. L 375 $\mu \mathrm{m}, \mathrm{Wb} 30 \mu \mathrm{m} ; \mathrm{n}=1$.

Affinities: C. fusus. Unlike in C. fusus, in C. bigelowii the cell is markedly inflated in the middle, and therefore the cell body is well separated from the horns.

A new record for the State of Veracruz. Extremely rare in NPSAV (the only specimen observed was collected on 1 March 2008 relatively far from the shore: $10^{\circ} 02^{\prime 4} 43.1^{\prime \prime}$ N, 95²9'25.4" W).

References: Kofoid, 1907a*: 170, pl. 3, fig. 22; Jörgensen, 1911*: 25, fig. 44; Böhm, 1931b*: 43, fig. 37b; Steemann Nielsen, 1934*: 13, fig. 18; Schiller, 1937*: 376, fig. 414b; Graham \& Bronikovsky, 1944*: 22, fig. 11I, K-M; Wood, 1963*: 39, fig. 143; Subrahmanyan, 1968*: 28, fig. 46, 47; Steidinger \& Williams, 1970**: 44, pl. 4, fig. 11; Konovalova, 1998*: 141, fig. 29(3).

4. Ceratium fusus (Ehrenb.) Dujard., 1841 (Pl. 1, Fig. 6 and 7; Pl. 10, Fig. 4)

Bas.: Peridinium fusus Ehrenb., 1834: 271, 1835.

Syn: C. seta (Ehrenb.) Kofoid, 1908: 387.

Cells spindle-shaped, long. Epitheca tapers continuously into a long apical horn and hypotheca tapers into a long left antapical horn. Apical and left antapical 
horns equal or subequal in length and slightly curved. A reduced right antapical horn may be present. Widest point adjacent to the cingulum. L 243-580 $\mu \mathrm{m}(422.4 \pm 80.9$ $\mu \mathrm{m}), \mathrm{Wb} 15-25 \mu \mathrm{m}(20.4 \pm 4.0 \mu \mathrm{m}) ; \mathrm{n}=22$.

Affinities: C. extensum, C. inflatum, C. longirostrum, C. bigelowii. I preferred not to distinguish the two forms of $C$. fusus given in Steidinger et al. (2009) for the Gulf of Mexico.

Records in the State of Veracruz: Ochoa-Figueroa, 1978; Avendaño-Sánchez \& Sotomayor-Navarro, 1982; Echeverría-Valencia, 1983; Figueroa-Torres, 1990***; Suchil-Vilchis, 1990*; Zamudio-Resendiz, 1998; Aquino-Cruz, 2002***; LegaríaMoreno, 2003; Estradas-Romero, 2004. Very common in NPSAV throughout the year.

References: Ostenfeld, 1903*: 587, fig. 145, 146; Paulsen, 1908*: 90, fig. 123; Jörgensen, 1911*: 29, fig. 51-53; 1920*: 41, fig. 30; Lebour, 1925*: 146, pl. 31, fig. 1; Wailes, 1928*: 5, pl. 1, fig. 5, 6, pl. 12, fig. 21, 22 (a teratologic form); Böhm, 1931b*: 14, fig. 10c-f; Steemann Nielsen, 1934*: 14, fig. 25, 26; Schiller, 1937*: 378, fig. 418a, b; Rampi, 1939*: 303, fig. 12, 13; Graham \& Bronikovsky, 1944*: 25, fig. 11EE, 13A-D; Kiselev, 1950*: 245, fig. 419; Wood, 1954*: 282, fig. 202; 1968*: 29, fig. 58; Kato, 1957*: 13, pl. 3, fig. 5a-c, 6a, b (C. fusus and C. fusus var. seta); Curl, 1959*: 306, fig. 116; Margalef, 1961a*: 81, fig. 26e-g: López, 1966*: fig. 11; Sournia, 1968*: 408, 32, 33, 34(?) (three varieties are illustrated); Subrahmanyan, 1968*: 31, fig. 55, pl. 1, fig. 3-6; Steidinger \& Williams, 1970**: 45, pl. 8, fig. 21a, b; Drebes, 1974**: 145, fig. 128a; Hassan \& Saifullah, 1974*: 85, fig. 9 (C. fusus var. seta); Taylor, 1976*: 66, pl. 13, fig. 129, 130, 136, 137; Pesantes-Santana, 1978*: 12, pl. 6, fig. 3-7; Trégouboff, 1978*: 115, pl. 25, fig. 13A-D; Tester \& Steidinger, 1979**: 28, pl. 11, fig. 63; Burns \& Mitchell, 1980***: 150, fig. 3; Dodge, 1982*: 231, fig. 29C; Dowidar, 1983*: 11, pl. 1, fig. 8; Balech, 1988*: 132, pl. 54, fig. 5, 6, 8; Konovalova et al., 1989***: 132, fig. 49(5-7), pl. 15, fig. 7 (three varieties are illustrated); Delgado \& Fortuño, 1991***: 6, pl. 8, fig. c, d; Licea et al., 1995**: 37, pl. 3, fig. 2; 2004**: fig. 3, 12 (var. fusus and var. seta); Wiktor \& Okolodkov, 1995*: 36, fig. 10a-c; Steidinger \& Tangen, 1997*: 472, pl. 25; Konovalova, 1998****: fig. 29(5, 6, 15), pl. 13, fig. 9 (three varieties are illustrated); Bérard-Therriault et al., 1999**: 164, pl. 83a; Avancini et al., 2006***: 289, fig. A-D (var. seta); Hoppenrath et al., 2009**: 173, fig. 70b, c; Yongshui, 2009**: pl. 2, fig. 8 .

5. Ceratium inflatum (Kof.) Jörg., 1920 (Pl. 1, Fig. 8; P1. 10, Fig. 5)

Bas.: Ceratium pennatum f. inflatum Kofoid, 1907 (Bull. Mus. Comp. Zool. Harv. Coll. 50, 6): 172, pl. 2, fig. 13. 
Cells spindle-shaped, long. Epitheca tapers into a long apical horn and hypotheca tapers into a long left antapical horn; however, the cell body is distinguished, inflated. Apical and left antapical horns equal or subequal in length; apical horn straight or slightly curved and the left antapical horn more curved continuously or rather abruptly at its distal third. A reduced right antapical horn may be present. Widest point adjacent to the cingulum. L 595-690 $\mu \mathrm{m}(634 \pm 39.3 \mu \mathrm{m}), \mathrm{Wb} 22.5-32.5$ $\mu \mathrm{m}(27.4 \pm 3.3 \mu \mathrm{m}) ; \mathrm{n}=8$. Rare in NPSAV (March, Oct.).

Affinities: C. fusus, C. longirostrum, C. extensum, C. bigelowii. The species is distinguished from the former three species by its more inflated cell body.

References: Jörgensen, 1911*: 25, fig. 45, 46, 48a; 1920*: 35, fig. 25; Böhm, 1931a*: 353, fig. 3, 4; 1931b*: 14, fig. 10a, b; Schiller, 1937*: 376, fig. 415a, b; Graham \& Bronikovsky, 1944*: 23, fig. 11O-S; Kiselev, 1950*: 245, fig. 462; Wood, 1954*: 281, fig. 198; Silva, 1956*: 56, pl. 7, fig. 9; Kato, 1957*: 14, pl. 3, fig. 7; López, 1966*: fig. 10; Sournia, 1968*: 412, fig. 36; Subrahmanyan, 1968*: 29, fig. 48, 49; Steidinger \& Williams, 1970**: 46, pl. 10, fig. 25; Trégouboff, 1978*: 115, pl. 25, fig. 10; Dodge, 1982*: 231, fig. 29B; Steidinger \& Tangen, 1997*: 474, pl. 25; Konovalova, 1998*: 140, fig. 29(2); Yongshui, 2009**: pl. 2, fig. 9.

6. Ceratium belone Cleve, 1900 (Pl. 2, Fig. 1 and 2; Pl. 10, Fig. 6)

Cells spindle-shaped, long. Epitheca continuously tapers into a long apical horn. Hypotheca with two well developed antapical horns, parallel to each other. Left antapical horn about twice as long as right one. Widest region adjacent to the cingulum and occupies nearly all the proximal part of hypotheca. L 680-880 $\mu \mathrm{m}$ (729.5 $\pm 100.7 \mu \mathrm{m}), \mathrm{Wb} 27.5-31 \mu \mathrm{m}(29.6 \pm 1.5 \mu \mathrm{m}) ; \mathrm{n}=4$.

Records in the State of Veracruz: Zamudio-Resendiz, 1998. Extremely rare in NPSAV; four specimens were found on 11 December 2007 at st. 2 and on 1 March 2008 at st. 4.

References: Jörgensen, 1911*: 19, fig. 28a, b; 1920*: 22, fig. 14; Steemann Nielsen, 1934*: 10, fig. 10; Schiller, 1937*: 369, fig. 407a; Rampi, 1942*: 222, fig. 2; Graham \& Bronikovsky, 1944*: 19, fig. 8; Sournia, 1968*: 399, fig. 22; Subrahmanyan, 1968*: 20, fig. 30; Wood, 1968*: 24, fig. 40; Steidinger \& Williams, 1970**: 44, pl. 4, fig. 10; Taylor, 1976*: 58, pl. 12, fig. 119; Trégouboff, 1978*: 114, pl. 25, fig. 6; Tester \& Steidinger, 1979**: 27, pl. 10, fig. 57; Dowidar, 1983*: 10, pl. 2, fig. 4; Balech, 1988*: 132, pl. 56, fig. 1; Delgado \& Fortuño, 1991*: fig. 6B; Licea et al., 1995: 30, pl. 17, fig. 6 (also, referred by mistake to pl. 1, fig. 5, in which C. candelabrum is given); Yongshui, 2009***: 8, fig. 8, pl. 1, fig. 5 . 
7. Ceratium longirostrum Gourret, 1883 (P1. 2, Fig. 3 and 4; Pl. 10, Fig. 7)

Cells needle-shaped, very long. Epitheca tapers into a long apical horn and hypotheca tapers into a long left antapical horn. Apical and left antapical horn equal or subequal in length, apical horn being slightly curved and left antapical horn notably curved. A reduced right antapical horn may be present. Widest point adjacent to the cingulum. L 268-690 $\mu \mathrm{m}(621.8 \pm 78.6 \mu \mathrm{m}), \mathrm{Wb}$ 17.5-32.5 $\mu \mathrm{m}(27.9 \pm 3.9 \mu \mathrm{m}) ; \mathrm{n}=29$.

Affinities: C. fusus, C. extensum, C. inflatum.

Records in the State of Veracruz: Figueroa-Torres, 1990***. Rare in NPSAV (Jan. to March, May, Aug. to Dec.).

References: Jörgensen, 1920*: 37, fig. 26, 27; Böhm, 1931a*: 354, fig. 5; Steemann Nielsen, 1934*: 13, fig. 21; Schiller, 1937*: 376, fig. 416a, b; Rampi, 1939*: 303, fig. 9; Graham \& Bronikovsky, 1944*: 24, fig. 11T-V; Wood, 1954*: 281, fig. 199; 1968*: 35, fig. 75; Silva, 1956*: 57, pl. 7, fig. 10; López, 1966*: fig. 15; Sournia, 1968*: 413, fig. 37; Subrahmanyan, 1968*: 30, fig. 50-52; Steidinger \& Williams, 1970**: 46, pl. 10, fig. 27; Hassan \& Saifullah, 1974*: 85, fig. 8; Taylor, 1976*: 67, pl. 13, fig. 131a, b; Pesantes-Santana, 1978*: 14, pl. 7, fig. 4; Trégouboff, 1978*: 115, pl. 25, fig. 11; Dowidar, 1983*: 12, pl. 2, fig. 8; Balech, 1988*: 134, pl. 55, fig. 10, 11; Delgado \& Fortuño, 1991*: fig. 6C; Licea et al., 1995**: 41, pl. 3, fig. 9.

\section{Subgenus Ceratium (= Biceratium (Vanhöffen) Ostenf.)}

8. Ceratium candelabrum (Enrenb.) Stein, 1883 (P1. 2, Fig. 5; Pl. 9, Fig. 1; Pl. 10, Fig. 8)

Bas.: Peridinium candelabrum Ehrenb., 1860: 792, pl. 1, fig. 2, 3.

Cells with two robust or stout antapical horns, slightly divergent, left one slightly longer and sometimes thicker. Cell body is about twice as broad as it is high. Epitheca in the form of low cone, with well separated apical horn inserted eccentrically. Hypotheca between the antapical horns markedly inclined towards the cingulum. Widest point adjacent to the cingulum. L 145-345 $\mu \mathrm{m}(243.0 \pm 52.2 \mu \mathrm{m})$, $\mathrm{Wb} 68-94 \mu \mathrm{m}(78.0 \pm 7.0 \mu \mathrm{m}) ; \mathrm{n}=20$. Chains of 2 cells were observed.

Note: Steidinger et al. (2009) reported two forms of this species for the Gulf of Mexico. The name of Ceratium depressum ascribed to Gourret (the only author, whose name appears in parentheses) given by Suchil-Vilchis (1990) for Veracruz should be considered a nomen nudum. 
Records in the State of Veracruz: Avendaño-Sánchez \& Sotomayor-Navarro, 1982; Figueroa-Torres, 1990*; Zamudio-Resendiz, 1998. Rare to common in NPSAV (Jan. to March, May, July, Aug., Nov., Dec.).

References: Paulsen, 1908*: 88, fig. 120; Jörgensen, 1920*: 11, fig. 5, 6; Lebour, 1925*: 143, fig. 45b, c, pl. 30, fig. 2; Böhm, 1931a*: 351, fig. 1, 2 (C. candelabrum f. eucandelabrum n. f. and f. hiemale n. f.), 24 (a teratologic form); 1931b*: 8, fig. 3a-d; Steemann Nielsen, 1934*: 8, fig. 6, 7; Schiller, 1937*: 364, fig. 401; Rampi, 1939*: 302, fig. 4, 5, 7 (three infraspecific taxa are illustrated); 1951*: 6, fig. 7 (a teratologic specimen); Graham \& Bronikovsky, 1944*: 17, fig. 6; Kiselev, 1950*: 242, fig. 408; Kato, 1957*: 12, pl. 3, fig. 2 (C. candelabrum and C. candelabrum var. depressum); López, 1966***: 362, fig. 3, 4, 52, 56-58, 88, 89, photo 1(1, 2) (three infraspecific taxa are illustrated); Sournia, 1968*: 390, fig. 14-17 (two varieties are illustrated; a new combination C. candelabrum f. subrotundum (Ostenf.) Sournia is proposed); Subrahmanyan, 1968*: 17, fig. 16-20; Wood, 1968*: 25, fig. 44; Hassan \& Saifullah, 1974*: 84, fig. 1; Taylor, 1976*: 59, pl. 12, fig. 124-126; Pesantes-Santana, 1978*: 7, pl. 2, fig. 1-3; Trégouboff, 1978*: 114, pl. 25, fig. 4A, B; Burns \& Mitchell, 1980***: 149, fig. 1, 2; Dodge, 1982*: 227, fig. 28A, pl. 7, fig. d; 1985***: 94; Dowidar, 1983*: 9, pl. 2, fig. 2; Balech, 1988*: 128, pl. 56, fig. 17, 18, pl. 57, fig. 4, 5; Delgado \& Fortuño, 1991****: fig. 6I; 5, pl. 5, fig. b; Licea et al., 1995****: 31, pl. 1, fig. 5, pl. 17, fig. 8 (also, referred by mistake to pl. 17, fig. 9, in which C. pentagonum is given); Steidinger \& Tangen, 1997*: 471, pl. 27; Konovalova, 1998*: 133, fig. 28(14); Avancini et al., 2006***: 281, fig. A-H; Yongshui, 2009******: 9, fig. 10, 11, pl. 1, fig. 7, 8, pl. 9, fig. 1A, B (var. candelabrum and var. depressum).

9a. Ceratium furca (Ehrenb.) Clap. et J. Lachm., 1859 var. furca (Pl. 2, Fig. 6; P1. 9, Fig. 2; P1. 10, Fig. 9)

Bas.: Peridinium furca Ehrenb., 1835: 574, pl. 2(2).

Syn.: Ceratium furca var. berghii Lemmermann, 1899: 366; C. furca var. eugrammum (Ehrenb.) J. Schill., 1937: 368, fig. 405a, b.

Cells with two robust antapical horns, parallel to each other or slightly divergent, parallel or slightly convergent, left one being about twice as long. Epitheca tapers into a rather long apical horn. Hypotheca between the antapical horns markedly inclined towards the cingulum. Widest point adjacent to the cingulum. L 155-260 $\mu \mathrm{m}(214.0 \pm 28.6 \mu \mathrm{m}), \mathrm{Wb} 30-42.5 \mu \mathrm{m}(35.9 \pm 4.3 \mu \mathrm{m}) ; \mathrm{n}=20$. Chains of 2 cells were observed. 
Records in the State of Veracruz: Avendaño-Sánchez \& Sotomayor-Navarro, 1982; Echeverría-Valencia, 1983*; Hernández-Mendiola, 1988; Figueroa-Torres, 1990* **; Suchil-Vilchis, 1990; Zamudio-Resendiz, 1998; Aquino-Cruz, 2002***; García-Reséndiz, 2003; Legaría-Moreno, 2003; Estradas-Romero, 2004; TejedaHernández, 2005**. Very common in NPSAV throughout the year.

References: Paulsen, 1908*: 90, fig. 122; 1931*: 76, fig. 46; Jörgensen, 1920*: 17, fig. 7-12; Lebour, 1925*: 145, pl. 30, fig. 3; Wailes, 1928*: 5, pl. 1, fig. 8, pl. 2 , fig. 10; Böhm, 1931b*: 8, fig. 4-8; Steemann Nielsen, 1934***: 9, fig. 8, 9, photo 1(5, 6); Schiller, 1937*: 367, fig. 404-405; Rampi, 1939*: 302, fig. 8; Graham \& Bronikovsky, 1944*: 18, fig. 7; Kiselev, 1950*: 243, fig. 415, 416, 427; Wood, 1954*: 274, fig. 189a-c; 1968*: 29, fig. 57; Kato, 1957*: 12, pl. 3, fig. 4a, b; Curl, 1959*: 305, fig. 115; López, 1966***: 371, fig. 6, 7, 68, 72, 92, 93 (C. furca eugrammum and C. furca Berghii), photo 1(5, 6); Sournia, 1968*: 395, fig. 18-20 (var. furca and var. eugrammum); Steidinger et al., 1967**: pl. 5, fig. e; Subrahmanyan, 1968*: 20, fig. 21-29, pl. 2, fig. 7-12; Steidinger \& Williams, 1970**: 45, pl. 7, fig. 20a, b; Hermosilla, 1973*: 62, pl. 33, fig. 1, 2, 7, 8; Drebes, 1974**: 145, fig. 128b; Hassan \& Saifullah, 1974*: 84, fig. 2, 3 (var. furca and var. eugrammum); Taylor, 1976*: 60, pl. 12, fig. 109; Trégouboff, 1978*: 114, pl. 25, fig. 5A, B; Burns \& Mitchell, 1980***: 150, fig. 4-10; Dodge, 1982*: 228, fig. 28C, pl. 8, fig. e; 1985***: 96, right fig.; PesantesSantana, 1978* (other varieties than var. furca): 11, pl. 8, fig. 1-3 (Ceratium furca var. berghii f. bergii López, 1966; with an orthographic error in the name of the form), pl. 4, 5 (C. furca var. eugrammun (Ehrenb.) J. Schill., 1937; with an orthographic error in the name of the variety); Dowidar, 1983*: 9, pl. 2, fig. 3; Balech, 1988*: 131, pl. 56, fig. 4-6; Konovalova et al., 1989*: 132, fig. 49(4); Delgado \& Fortuño, 1991****: fig. 6D, E; 5, pl. 3, fig. a, b; Licea et al., 1995***: 36, pl. 2, fig. 7; 2004**: fig. 2, 8 (also as C. furca var. eugrammun); Wiktor \& Okolodkov, 1995*: 34, fig. 9a, b; Steidinger \& Tangen, 1997*: 472, pl. 25; Konovalova, 1998*: 136, fig. 28(7); Avancini et al., 2006* **: 286, fig. A, B; Alonso-Rodríguez et al., 2008**: 127; Hoppenrath et al., 2009**: 173, fig. 70d-g; Yongshui, 2009******: 12, fig. 13, 14, pl. 1, fig. 9, 10, pl. 9, fig. 2A, B (var. furca and var. eugrammum).

9b. Ceratium furca var. hircus (Schröd.) Margalef, 1961 ex Sournia, 1973 (Pl. 2, Fig. 7; Pl. 3, Fig. 1; Pl. 9, Fig. 3; Pl. 10, Fig. 10)

Bas.: Ceratium hircus Schröder, 1909: 213, fig. 2.

Cells with two robust, slightly divergent antapical horns, equal or subequal in length. Epitheca tapers into a rather long apical horn. Hypotheca between the 
antapical horns markedly inclined towards the cingulum. Widest point adjacent to the cingulum. L 137-220 $\mu \mathrm{m}(166.7 \pm 11.3 \mu \mathrm{m}), \mathrm{Wb} 31-53 \mu \mathrm{m}(36.8 \pm 4.3 \mu \mathrm{m}) ; \mathrm{n}=28$. Chains of 2 cells were observed.

Records in the State of Veracruz: Figueroa-Torres, 1990***; Guerra-Martínez \& Lara-Villa, 1996**; Zamudio-Resendiz, 1998; Aquino-Cruz, 2002***; LegaríaMoreno, 2003; Tejeda-Hernández, 2005**. Common in NPSAV throughout the year.

References: Schiller, 1937*: 369, fig. 406; Margalef, 1961a*: 81, fig. 26c, d; Steidinger \& Williams, 1970**: 45, pl. 9, fig. 24a, b; Tester \& Steidinger, 1979**: 28, pl. 11, fig. 65; López-Baluja, 1980*: 5, fig. 2; Balech, 1988*: 196, pl. 69, fig. 6; Licea et al., 1995*****: 37, pl. 2, fig. 9, pl. 3, fig. 1; Yongshui, 2009*: 13, fig. 15, 16 (var. hircus and var. sinicum Nie).

10. Ceratium pentagonum Gourret, 1883 var. tenerum Jörg., 1920 (Pl. 3, Fig. 2 and 3; P1. 8, Fig. 1; P1. 10, Fig. 11)

Cells pentagonal with two slightly diverging antapical horns. Antapical horns short, left one about 1.5 times longer. Epitheca in the form of low cone, with well separated apical horn inserted centrically. Hypotheca between the antapical horns markedly inclined towards the cingulum. Widest point adjacent to the cingulum. $\mathrm{L}$ 120-210 $\mu \mathrm{m}(156.2 \pm 23.4 \mu \mathrm{m}), \mathrm{Wb} 46-55 \mu \mathrm{m}(51.3 \pm 3.8 \mu \mathrm{m}) ; \mathrm{n}=21$.

Records in the State of Veracruz: Ochoa-Figueroa, 1978; Avendaño-Sánchez \& Sotomayor-Navarro, 1982; Echeverría-Valencia, 1983*: pl. 8, fig. 19B(?), non 19A (the cell illustrated in fig. 19A is likely C. minutum); Figueroa-Torres, 1990* **; Suchil-Vilchis, 1990; Zamudio-Resendiz, 1998; Aquino-Cruz, 2002***; EstradasRomero, 2004; Tejeda-Hernández, 2005**. Very common in NPSAV throughout the year.

References: Jörgensen, 1911*: 20, fig. 31, 32; 1920*: 24, fig. 15-17; Böhm, 1931b*: 12, fig. 9b; Steemann Nielsen, 1934*: 11, fig. 12; Rampi, 1939*: 302, fig. 16, 17, 20 (two forms are illustrated); Graham \& Bronikovsky, 1944*: 20, fig. 10C, D, H-N; Kiselev, 1950*: 243, fig. 417, 418; Silva, 1952a*: 39, pl. 3, fig. 15; 1956*: 51, pl. 7, fig. 3, 4 (subsp. robustum, subsp. tenerum and var. turgidum); Gaarder, 1954*: 15, fig. 14 (as C. pentagonum f. tenerum (Jörgensen); Kato, 1957*: 13, pl. 4, fig. 9; Curl, 1959*: 306, fig. 120; Margalef, 1961a*: 81, pl. 6; López, 1966***: 367, fig. 5, 59, 63, 90, photo 1(3, 4); Sournia, 1968*: 400, fig. 23, 24; Subrahmanyan, 1968*: 23, fig. 32, 33; Wood, 1968*: 37, fig. 82, 39; Steidinger \& Williams, 1970**: 47, pl. 12, fig. 31; Hermosilla, 1973*: 62, pl. 32, fig. 4-6, 8 (as C. pentagonum var. robustum (Cleve) Jörg.); Hassan \& Saifu1lah, 1974*: 84, fig. 5 (var. robustum); Balech, 1976*: 90, fig. 12 (C. pentagonum ssp. 
grande Mangin, 1926); 1988*: 128, pl. 56, fig. 14-16, pl. 57, fig. 1-3; Taylor, 1976*: 62, pl. 12, fig. 111-113 (three varieties are illustrated); Trégouboff, 1978*: 114, pl. 25, fig. 7; Tester \& Steidinger, 1979**: 29, pl. 11, fig. 70; Dowidar, 1983*: 10, pl. 3, fig. 1; Dodge, 1985***: 96, left fig.; Pesantes-Santana, 1978*: 15, 16, pl. 8, fig. 6, 7; Konovalova et al., 1989*: 136, fig. 50(4); Delgado \& Fortuño, 1991****: fig. 6N; 6, pl. 9, fig. c; Licea et al., 1995***: 44, pl. 1, fig. 6, pl. 4, fig. 5, pl. 19, fig. 7-9; 2004*: fig. 6; Steidinger \& Tangen, 1997*: 477, pl. 26; Konovalova, 1998***: 134, fig. 28(11, 12), pl. 12, fig. 6 (var. pentagonum and var. turgidum Jörg.); Avancini et al., 2006***: 293, fig. A-D.

\section{Ceratium teres Kof., 1907 (Pl. 3, Fig. 4; Pl. 10, Fig. 12)}

Cells with a body with straight or slightly convex sides and slender, delicate horns. Epitheca triangular, with well separated apical horn. Antapical horns short, left one about twice as long. Widest point adjacent to the cingulum. Theca not sculptured or only weakly sculptured. L 100-153 $\mu \mathrm{m}(129.7 \pm 15.8 \mu \mathrm{m}), \mathrm{Wb} 35-41 \mu \mathrm{m}$ $(38.4 \pm 2.4 \mu \mathrm{m}) ; \mathrm{n}=23$.

Affinities: C. kofoidii, C. lineatum. C. teres is distinguished from C. kofoidii by its longer cells, usually with slightly convex sides of the cell body and poorly marked cingulum.

Records in the State of Veracruz: Figueroa-Torres, 1990***; Zamudio-Resendiz, 1998. Very common in NPSAV throughout the year.

References: Kofoid, 1907b*: 308, fig. 34-36; Jörgensen, 1911*: 21, pl. 2, fig. 34, 35; Böhm, 1931b*: 12, fig. 9d; Steemann Nielsen, 1934*: 11, fig. 14; Schiller, 1937*: 372, fig. 409a, b; Rampi, 1939*: 303, fig. 6; Graham \& Bronikovsky, 1944*: 21, fig. 11B-D; López, 1966***: 371, fig. 8, 64, 91, photo 1(7); Sournia, 1968*: 405, fig. 28; Subrahmanyan, 1968*: 24, fig. 34, 35; Wood, 1968*: 40, fig. 90; Steidinger \& Williams, 1970**: 47, pl. 13, fig. 35a, b; Taylor, 1976***: 63, pl. 12, fig. 110, pl. 40, fig. 484; Pesantes-Santana, 1978*: 17, fig. 9; Trégouboff, 1978*: 115, pl. 25, fig. 8; Burns \& Mitchell, 1980***: 150, fig. 15; Dowidar, 1983*: 11, pl. 1, fig. 3; Balech, 1988*: 131, pl. 56, fig. 7; Licea et al., 1995**: 47, pl. 5, fig. 3; 2004**: fig. 5; Steidinger \& Tangen, 1997*: 478, pl. 26; Konovalova, 1998*: 135, fig. 28(13); Yongshui, 2009* $* * * * *$ : 18, fig. 22, pl. 2, fig. 4, pl. 10, fig. 2 .

12. Ceratium kofoidii Jörg., 1911 (Pl. 3, Fig. 5; Pl. 10, Fig. 13)

Cells with a body with straight sides and slender, delicate horns. Epitheca triangular, with well separated apical horn. Antapical horns short, the left being slightly 
longer. Widest point adjacent to the cingulum. Theca not sculptured or only weakly sculptured. L 110-210 $\mu \mathrm{m}$ (141.6 $\pm 26.8 \mu \mathrm{m}), \mathrm{Wb} 20-28 \mu \mathrm{m}(24.4 \pm 1.6 \mu \mathrm{m}) ; \mathrm{n}=20$.

Affinities: $C$. lineatum, $C$. teres. $C$ kofoidii is distinguished from $C$. teres by its smaller size, straight sides of the cell body and a well marked cingulum.

Records in the State of Veracruz: Suchil-Vilchis, 1990; Zamudio-Resendiz, 1998; Estradas-Romero, 2004. Very common in NPSAV throughout the year.

References: Jörgensen, 1911*: 23, fig. 38, 39; 1920*: 33, fig. 20; Böhm, 1931b*: 12, fig. 9c, e-g; Steemann Nielsen, 1934*: 11, fig. 15; Schiller, 1937*: 373, fig. 412a, b; Rampi, 1942*: 223, fig. 5; Graham \& Bronikovsky, 1944*: 21, fig. 11H; Kiselev, 1950*: 244, fig. 409; Silva, 1956*: 55, pl. 7, fig. 7; Sournia, 1968*: 406, fig. 29; Subrahmanyan, 1968*: 26, fig. 41, 42; Wood, 1968*: 33, fig. 69; Steidinger \& Williams, 1970**: 46, pl. 10, fig. 26; Hassan \& Saifullah, 1974*: 84, fig. 6; Dowidar, 1983*: 11, pl. 1, fig. 4; Licea et al., 1995*: 41, pl. 19, fig. 2; 2004**: fig. 7; Steidinger \& Tangen, 1997*: 475, pl. 25; Konovalova, 1998****: 137, fig. 29(8), pl. 13, fig. 5-8; AlonsoRodríguez et al., 2008**: 128.

\section{Subgenus Tripoceratium Kofoid}

13. Ceratium hexacanthum Gourret, 1883 (P1. 3, Fig. 6 and 7; Pl. 9, Fig. 4; Pl. 11, Fig. 1)

Syn.: Ceratium tripos var. reticulata Pouchet, 1883: 423, fig. 3; C. reticulatum (Pouchet) Cleve, 1903: 342.

Cell body covered with coarse reticulations in the form of ridges. Epitheca convex, cell body well differentiated from the apical horn. Right antapical horn arises immediately behind the cingulum and bends laterally-anteriorly. Left antapical horn bends around toward the dorsal side of the cell so that its distal part is directed ventrally-right. Widest point adjacent to the antapical horns. L 85-735 $\mu \mathrm{m}$ $(422 \pm 223.1 \mu \mathrm{m}), \mathrm{Wb} 70-87.5 \mu \mathrm{m}(81.3 \pm 4.7 \mu \mathrm{m})$, Wt $250-440 \mu \mathrm{m} 333.6 \pm 73.2 \mu \mathrm{m})$; $\mathrm{n}=7$. Chains of 2 cells were observed.

Note: Although Licea et al. (2004) consider this dinoflagellate species one of the 30 most common in the southern Gulf of Mexico, it is extremely rare in Veracruz waters, including NPSAV (March, May, July, Aug., Oct. to Dec.).

Records in the State of Veracruz: Figueroa-Torres, 1990*.

References: Karsten, 1907*: pl. 50, fig. 4, 5 (as C. tripos reticulatum Pouchet var. contorta Gourret); Pavillard, 1916*: 19, fig. 1; Jörgensen, 1920*: 101, fig. 94; 
Böhm, 1931a*: 366, fig. 22 (as C. hexacanthum f. contortum (Lemmermann), 23; Steemann Nielsen, 1934*: 29, fig. 73; Schiller, 1937*: 421, fig. 462a-c; Rampi, 1939*: 308, fig. 44; 1942*: 227, fig. 710-712 (two forms are illustrated); Graham \& Bronikovsky, 1944*: 44, fig. 27F, G; Kiselev, 1950*: 254, fig. 438; Wood, 1954*: 306, fig. 462a, b; 1968*: 31, fig. 63; López, 1966*: fig. 38; Sournia, 1968*: 484, fig. 98 (six infreaspecific taxa are proposed, including a new combination $C$. hexacanthum $\mathrm{f}$. pavillardii (Rampi) Sournia); Subrahmanyan, 1968*: 72, fig. 140, 141; Steidinger \& Williams, 1970**: 45, pl. 9, fig. 23a-c; Hassan, 1976*: 291, fig. 17a, b; Taylor, 1976*: 70, pl. 22, fig. 214, 215, 219; Pesantes-Santana, 1978*: 13, pl. 10, fig. 4, 5; Trégouboff, 1978*: 116, pl. 26, fig. 13, 14A, B; Tester \& Steidinger, 1979**: 28, pl. 11, fig. 64; Dodge, 1982*: 236, fig. 30H, pl. 7, fig. e; Dowidar, 1983*: 20, pl. 5, fig. 6; Balech, 1988*: 152, pl. 69, fig. 1, 2; Konovalova et al., 1989*: 134, fig. 49(8); Delgado \& Fortuño, 1991***: 6, pl. 7, fig. a-d; Licea et al., 1995*: 39, pl. 18, fig. 10a, b (as C. hexacanthum var. contortum Lemmermann); Steidinger \& Tangen, 1997*: 474, pl. 27; Konovalova, 1998*: 164, fig. 36(1); Yongshui, 2009*****: pl. 2, fig. 12, 13, pl. 12, fig. 1A-C, 2 (var. hexacanthum f. spirale and var. contortum).

14. Ceratium dens Ostenf. et J. Schmidt, 1901 (Pl. 3, Fig. 8; Pl. 9, Fig. 5 and 6; Pl. 11, Fig. 2)

Cell body almost triangular, with slightly convex sides of the epitheca. Right antapical horn about 3 to 4 times longer than left one, arises immediately behind the cingulum and bends laterally-anteriorly. Left antapical horn very short and bends laterally. Widest point adjacent to the antapical horns. L 152-290 $\mu \mathrm{m}(238.8 \pm 36.5$ $\mu \mathrm{m}), \mathrm{Wb} 64-83 \mu \mathrm{m}(74.4 \pm 4.4 \mu \mathrm{m})$, Wt 190-265 $\mu \mathrm{m}(232.0 \pm 19.5 \mu \mathrm{m}) ; \mathrm{n}=20$. Chains of 2 to 6 cells were observed.

Note: $C$. dens has been previously reported for the Gulf of Mexico only for West Florida waters (Steidinger et al., 2009), and thus it is a new record for the Mexican part of the Gulf. C. dens was also found in samples taken in 2009 near the northern coast of the Yucatan Peninsula (Okolodkov, unpubl.; F. del C. Merino-Virgilio, pers. comm.). The taxon presented by Balech (1988) for the SW Atlantic and by Licea et al. (1995) for the Mexican Pacific under the name of Ceratium dens is another species described later, Ceratium balechii Meave, Zamudio et Okolodkov (Meave del Castillo et al., 2003). The latter is conspecific with the taxon found in Ecuadorian waters under the name of C. tripos var. poncticum Jörg. (Pesantes-Santana, 1978: 19, pl. 13, fig. 3, 4) and in the Sea of Japan under the name of $C$. dens (Konovalova, 1998: 151, fig. 29(11). 
Records in the State of Veracruz: A new record for the State of Veracruz. Rare in NPSAV (Feb., March, Sep., Nov., Dec.).

References: Karsten, 1907*: pl. 48, fig. 8a, b; Jörgensen, 1911*: 31, fig. 58, Böhm, 1931b*: 15, fig. 11a-e; Steemann Nielsen, 1934*: 15, fig. 27; Schiller, 1937*: 381, fig. 420a, b; Wood, 1954*: 284, fig. 204; Sournia, 1968*: 457, fig. 80; Subrahmanyan, 1968*: 34, fig. 58, pl. 3, fig. 16; Hassan, 1976*: 287, fig. 1; Taylor, 1976*: 68, pl. 17, fig. 172; Dowidar, 1983*: 17, pl. 6, fig. 3; Gárate-Lizárraga, 2009*****: 167, fig. 1-11, 13-17; Yongshui, 2009*****: pl. 2, fig. 10, pl. 11, fig. 1A, B.

\section{Ceratium ranipes Cleve, 1900 (Pl. 4, Fig. 1 and 2; Pl. 11, Fig. 3)}

Cell body subtrapezoidal, with convex epitheca. Posterior membrane supported with strong spines. Right antapical horn arises immediately behind the cingulum. Antapical horns are directed anteriorly and are terminated with finger-shaped appendages. Widest point adjacent to the antapical horns. L $270 \mu \mathrm{m}, \mathrm{Wb} 55 \mu \mathrm{m}, \mathrm{Wt}$ $128 \mu \mathrm{m} ; \mathrm{n}=1$.

Records in the State of Veracruz: Figueroa-Torres, 1990*. Extremely rare in NPSAV (the only specimen observed was collected on 14 February 2006 at st. 4).

References: Karsten, 1907*: pl. 50, fig. 6, 7 (as C. palmatum Br. Schröder); Jörgensen, 1920*: 82, fig. 76; Böhm, 1931b*: 31, fig. 28-31; Paulsen, 1931*: 86, fig. 53A-C; Steemann Nielsen, 1934*: 24, fig. 58; Schiller, 1937*; 409, fig. 451a; Rampi, 1939*: 307, fig. 2 (C. ranipes Cleve f. palmatum (Schröder) Jörgensen); Graham \& Bronikovsky, 1944*: 37, fig. 19I-K, 20, 21A; Wood, 1954*: 299, fig. 227; 1968*: 38, fig. 84; López, 1966*: fig. 19, 20, Sournia, 1968*: 459, fig. 81, 82; Subrahmanyan, 1968*: 60, fig. 110; Steidinger \& Williams, 1970**: 47, pl. 13, fig. 33; Taylor, 1976*: 77, pl. 19, fig. 189-192; Trégouboff, 1978*: 115, pl. 26, fig. 10; Tester \& Steidinger, 1979**: 29, pl. 12, fig. 71 (C. ranipes var. palmatum (Schröder) Cleve); Dowidar, 1983*: 17, pl. 5, fig. 5; Balech, 1988*: 142, pl. 60, fig. 8, 9, pl. 61, fig. 1; Delgado \& Fortuño, 1991*: fig. 7H; Licea et al., 1995*: 46, pl. 20, fig. 1; Konovalova, 1998*: 148, fig. 30(12); Avancini et al., 2006***: 297, fig. A-D; Yongshui, 2009******: 53, fig. 61-63, pl. 4, fig. 2, 3A, B, pl. 14, fig. 2, 3 (three infraspecific taxa are illustrated).

16. Ceratium limulus Gourret, 1883 (Pl. 4, Fig. 3; Pl. 11, Fig. 4)

Cell body very robust, subquadrangular, with characteristic "shoulders", squared margins in the anterior part of the cell body, just near the base of the apical horn. Posterior margin of the cell is very convex. Apical horn very short and straight, 
well separated from the cell body, positioned centrally. Proximal parts of the antapical horns, which are also short, are directed laterally-forward; distally they bend, and both horns are situated very close to the cell body (the right antapical horn is attached to it) and are directed forward, finally becoming convergent. Widest point adjacent to the cingulum. L $95-112.5 \mu \mathrm{m}(103.8 \pm 12.4 \mu \mathrm{m}), \mathrm{Wb} 55-57.5 \mu \mathrm{m}(56.3 \pm 1.8$ $\mu \mathrm{m})$, Wt $84-85 \mu \mathrm{m}(84.5 \pm 0.7 \mu \mathrm{m}) ; \mathrm{n}=2$.

Records in the State of Veracruz: Figueroa-Torres, 1990*. Extremely rare in NPSAV (the only two specimens observed were collected on 27 December 2005 and on 29 January 2008 relatively far from the shore, at sts. 2 and 8).

References: Jörgensen, 1911*: 57, fig. 122; 1920*: 77, fig. 72; Böhm, 1931a*: 361, fig. 13, 14; 1931b*: 31, fig. 27b; Steemann Nielsen, 1934*: 24, fig. 45; Schiller, 1937*: 407, fig. 448a-c; Rampi, 1939*: 307, fig. 19; Graham \& Bronikovsky, 1944*: 35, fig. 19A; Kato, 1957*: 17, pl. 5, fig. 15; Sournia, 1968**: 458, pl. 1, fig. 5; Subrahmanyan, 1968*: 56, fig. 103-105; Wood, 1968*: 34, fig. 71; Trégouboff, 1978*: 115, pl. 26, fig. 7; Delgado \& Fortuño, 1991***: 6, pl. 6, fig. c, d; Licea et al., 1995**: 41, pl. 3, fig. 7; Steidinger \& Tangen, 1997*: 475, pl. 28; Konovalova, 1998*: 141, fig. 34(1); Avancini et al., 2006***: 291, fig. A-F; Yongshui, 2009******: 71, fig. 82, pl. 6 , fig. 6 , pl. 17, fig. 3 .

17. Ceratium gibberum Gourret, 1883 var. dispar (Pouchet) Sournia, 1966 (Pl. 4, Fig. 4; Pl. 11, Fig. 5)

Syn.: Ceratium tripos var. megaceras Pouchet, 1883: 421, fig. C.

Cell body very robust, subpentagonal. Posterior margin of the cell is very convex. Epitheca is low. Apical horn moderately long and straight, strongly shifted to the left. Proximal part of the left antapical horn is directed laterally-forward and that of the right antapical horn is directed much more forward than laterally and then perpendicularly to the apical horn, just in front of the epitheca. Widest point adjacent to the cingulum. L 132-270 $\mu \mathrm{m}(201.0 \pm 97.6 \mu \mathrm{m}), \mathrm{Wb} 85-92 \mu \mathrm{m}(88.5 \pm 4.9 \mu \mathrm{m}), \mathrm{Wt}$ $142-148 \mu \mathrm{m}(145.0 \pm 4.2 \mu \mathrm{m}) ; \mathrm{n}=2$.

Records in the State of Veracruz: Figueroa-Torres, 1990*; García-Reséndiz, 2003. Extremely rare in NPSAV (only two specimens were observed, those collected on 7 June 2005 and on 11 December 2007 at sts. 2 and 3).

References: Paulsen, 1908*: 75, fig. 98; Jörgensen, 1911*: 49, fig. 106, 107, 109; 1920*: 70, fig. 67, 68; Lebour, 1925*: 152, fig. 49; Steemann Nielsen, 1934*: 22, fig. 48; Schiller, 1937*: 397, fig. 436a, b; Rampi, 1939*: 306, fig. 24; Graham \& Bronikovsky, 1944*: 33, fig. 17D-G; Kiselev, 1950*: 250, fig. 437; Wood, 1954*: 290, 
fig. 214a, b; ); 1968*: 30, fig. 61; Kato, 1957*: 16, pl. 5, fig. 17; Curl, 1959*: 306, fig. 117 (C. gibberum); López, 1966*: fig. 23 (C. gibberum); Sournia, 1968*: 446, fig. 73, 74 (two varieties are illustrated); Subrahmanyan, 1968*: 46, fig. 76-78; Steidinger \& Williams, 1970**: 45, pl. 8, fig. 22; Hassan, 1976*: 289, fig. 7; Taylor, 1976*: 84, pl. 19, fig. 187; Pesantes-Santana, 1978*: 12, pl. 9, fig. 1; Dodge, 1982*: 235, fig. 30F (C. giberrum); Delgado \& Fortuño, 1991***: 6, pl. 6, fig. a, b; Licea et al., 1995*: 38, pl. 18, fig. 7; Steidinger \& Tangen, 1997*: 472, pl. 27 (C. gibberum); Yongshui, 2009* *****: 69, fig. 80 , pl. 6, fig. 5, pl. 17, fig. 1 .

18. Ceratium vultur Cleve, 1900 f. vultur (Pl. 4, Fig. 5 and 6; Pl. 8, Fig. 7; Pl. 9, Fig. 7; Pl. 11, Fig. 6)

Syn.: Ceratium sumatranum (G. Karst.) Jörg., 1911 (incl. f. angulatum Jörg.): 73, fig. 154, 155, non 153.

Cell body very robust, somewhat trapezoidal. Theca strongly sculptured, with posterior membrane and membranes on the horns. Apical horn in the anterior cell of the colony thicker and longer than those in other cells. Right antapical horn bends laterally-anteriorly, arising immediately behind the cingulum. Widest point adjacent to the antapical horns. L 110-400 $\mu \mathrm{m}(182 \pm 116.3 \mu \mathrm{m})$, Wb 57.5-62.5 $\mu \mathrm{m}(59.3 \pm 1.9$ $\mu \mathrm{m})$, Wt $160-410 \mu \mathrm{m}(280 \pm 56.9 \mu \mathrm{m}) ; \mathrm{n}=22$. Chains of 2 to 5 cells were observed.

Note: Three infraspecific taxa have been found for the Gulf of Mexico (Steidinger et al., 2009).

Records in the State of Veracruz: Avendaño-Sánchez \& Sotomayor-Navarro, 1982; Figueroa-Torres, 1990***; Zamudio-Resendiz, 1998 (two forms were distinguished without their identification); Aquino-Cruz, 2002** (the cell illustrated in fig. 10 as Ceratium sp. is most likely C. vultur, judging from the proximal parts of the antapical horns). Extremely rare in NPSAV (March, Dec.).

References: Ostenfeld \& Schmidt, 1901*: 167, fig. 20; Karsten, 1907*: pl. 48, fig. 13-15 (also as C. tripos robustum Ostf. u. Schm.); Dangeard, 1927*: 378, fig. 42b, c (as C. vultur Cleve and C. sumatranum Karsten); Böhm, 1931b*: 38, fig. 35b, c, pl. 1 (C. vultur and C. sumatranum); Steemann Nielsen, 1934*: 27, fig. 65, non 66; Schiller, 1937*: 418, fig. 459a, b; Graham \& Bronikovsky, 1944*: 41, fig. 23A-H; Wood, 1954*: 304, fig. 233a; 1968*: 41, fig. 94; Kato, 1957*: 19, pl. 7, fig. 24 (C. sumatranum f. angulatum); Sournia, 1968*: 480, fig. 96, 97 (four forms are given); Subrahmanyan, 1968*: 68, fig. 131; Steidinger \& Williams, 1970**: 47, pl. 15, fig. 39 (C. vultur var. sumatranum); Hassan, 1976*: 291, fig. 15a, b (C. vultur var. sumatranum); Taylor, 1976****: 76, pl. 22, fig. 220-224, pl. 43, fig. 511 (five infraspecific 
taxa are illustrated); Pesantes-Santana, 1978*: 19, pl. 10, fig. 1, 2 (Ceratium vultur var. sumatranum (Karsten) Steemann Nielsen); Tester \& Steidinger, 1979**: 28, pl. 11, fig. 73a, b; Dowidar, 1983*: 20, pl. 6, fig. 5; Steidinger \& Tangen, 1997*: 482, pl. 6, 28; Balech, 1988*: 151, pl. 67, fig. 1-4; Licea et al., 1995*: pl. 5, fig. 8 (f. sumatranum), pl. 20, fig. 5 (var. vultur); Konovalova, 1998*: 163, fig. 34(3-5) (three infraspecific taxa are illustrated); Yongshui, 2009******: 49, fig. 57-60, pl. 4, fig. 1A, B, pl. 13, fig. 3, 4, pl. 14, fig. 1A, B (four infraspecific taxa are illustrated).

19. Ceratium lunula (Schimper ex G. Karst.) Jörg., 1911 (Pl. 4, Fig. 7; Pl. 11, Fig. 7) Bas.: Ceratium tripos lunula Schimper ex G. Karst., 1906 (Wiss. Ergebn. der Deutschen Tiefsee-Expedition auf dem Valdivia 1898-1899 2, 2, 2): 142, pl. 20, fig. 12, non al.

Cell body very robust, almost triangular, lacking a notch between the antapical horns. Posterior margin of the cell slightly flat. Apical horn straight, from short to long, positioned centrally, slightly inclined to the right. Antapical horns are long, directed laterally at their bases and then bent anteriorly so that in general they are parallel to each other or slightly convergent. Widest point adjacent to the antapical horns. L 350-470 $\mu \mathrm{m}(425.0 \pm 65.4 \mu \mathrm{m}), \mathrm{Wb} 82.5-85 \mu \mathrm{m}(84.2 \pm 1.4 \mu \mathrm{m}), \mathrm{Wt} 320-330$ $\mu \mathrm{m}(323 \pm 5.8 \mu \mathrm{m}) ; \mathrm{n}=3$.

Records in the State of Veracruz: Figueroa-Torres, 1990***. Extremely rare in NPSAV (Nov., Dec.).

References: Jörgensen, 1911*: 51, fig. 112-115; 1920*: 74, fig. 70; Böhm, 1931b*: 30, fig. 26; Steemann Nielsen, 1934*: 23, fig. 50; Schiller, 1937*: 399, fig. 439a, b; Graham \& Bronikovsky, 1944*: 33, fig. 17J-N; Wood, 1954*: 291, fig. 215a, b; 1968*: 35, fig. 76; Silva, 1956*: 61, pl. 8, fig. 3-5; Sournia, 1968*: 450, fig. 75, 76; Subrahmanyan, 1968*: 49, fig. 82-87, pl. 3, fig. 19, pl. 7, fig. 33; Steidinger \& Williams, 1970**: 46, pl. 10, fig. 28; Hassan, 1976*: 289, fig. 8; Taylor, 1976*: 85, pl. 16, fig. 171, pl. 18, fig. 183 (two varieties are illustrated); Pesantes-Santana, 1978*: 14, pl. 10, fig. 3; Delgado \& Fortuño, 1991*: fig. 6M; Licea et al., 1995*: 42, pl. 19, fig. 5 , non pl. 3 , fig. 10 (the illustrated specimen is a misidentification; most likely it is C. tripos var. breve); Steidinger \& Tangen, 1997*: 475, pl. 29; 150, fig. 29(10); Yongshui, 2009***: 73, fig. 85, pl. 6, fig. 8 .

20. Ceratium contortum (Gourret) Cleve, 1900 (Pl. 4, Fig. 8; Pl. 5, Fig. 1; Pl. 8, Fig. 6; P1. 11, Fig. 8; P1. 12, Fig. 1)

Bas.: Ceratium giberrum var. contortum Gourret, 1883: 35, pl. 2(33). 
Syn.: Ceratium longinum (G. Karst.) Jörg., 1911 (Intern. Rev. d. ges. Hydrob. u. Hydrog. 4, Suppl.-Heft, 1): 54, fig. 119a, b.

Cell body subtriangular, with slightly convex posterior margin, lacking a notch between the antapical horns. Apical horn very long, emerges from the left half of the cell body, is directed anteriorly at its base and then bends to the right. Right horn twisted, with its distal part directed to the left in var. saltans (Pl. 5, Fig. 1; Pl. 12, Fig. 1) or it is S-shaped and directed anteriorly in var. contortum (Pl. 4, Fig. 8; Pl. 11, Fig. 8). Widest point adjacent to the antapical horns. L 232-740 $\mu \mathrm{m}(417.6 \pm 112.7$ $\mu \mathrm{m}), \mathrm{Wb} 52-85 \mu \mathrm{m}(72.7 \pm 5.8 \mu \mathrm{m}), \mathrm{Wt} 182-250 \mu \mathrm{m}(210.4 \pm 16.1 \mu \mathrm{m}) ; \mathrm{n}=25$.

Note: Four varieties and one form of this species have been reported for the Gulf of Mexico (Steidinger et al., 2009).

Records in the State of Veracruz: Avendaño-Sánchez \& Sotomayor-Navarro, 1982 (also as C. longinum); Figueroa-Torres, 1990* **; Zamudio-Resendiz, 1998; García-Reséndiz, 2003. Common in NPSAV (March to Dec.).

References: Jörgensen, 1911*: 55, fig. 120; Böhm, 1931b*: 23, fig. 20a-c (C. contortum var. saltans); Steemann Nielsen, 1934*: 23, fig. 52, 53; Schiller, 1937*: 395, fig. 433; Graham \& Bronikovsky, 1944*: 34, fig. 18D-N; Silva, 1952b*: 604, pl. 6, fig. 10; 1956*: 61, pl. 8, fig. 2; Sournia, 1968***: 441, fig. $67-70$ (non 71, 72), pl. 2, fig. 9; Subrahmanyan, 1968*: 44, fig. 69-71; Wood, 1968*: 23, fig. 39 (the specimen illustrated as Ceratium azoricum is a misidentification and appears to be C. contortum), 26, fig. 48; Steidinger \& Williams, 1970**: 44, pl. 6, fig. 16a, b; Taylor, 1976*: 81, pl. 18, fig. 179-181 (three infraspecific taxa are illustrated), non 184; Trégouboff, 1978*: 115, pl. 26, fig. 2; Tester \& Steidinger, 1979**: 28, pl. 10, fig. 60; Balech, 1988*: 145, pl. 62, fig. 4, pl. 63, fig. 2; Hernández-Becerril, 1988**: 190, pl. 1, fig. 5 (C. contortum var. subcontortum (Schröder) Taylor, 1976); Licea et al., 1995**: 33, pl. 2, fig. 1; 2004**: fig. 19; Steidinger \& Tangen, 1997*: 472, pl. 27; Konovalova, 1998*: 152, fig. 32(2, 6) (also as C. longinum Karst.); Yongshui, 2009******: 64, fig. 73, 75, 76, pl. 6, fig. 1A, B, 2, pl. 16, fig. 2, 3A, B (three infraspecific taxa are illustrated), 72, fig. 84 (as C. longinum).

21. Ceratium karstenii Pavillard, 1907 (Pl. 5, Fig. 2; Pl. 12, Fig. 2)

Syn.: Ceratium arcuatum Cleve, 1900: 13, pl. 7, fig. 11; Ceratium contortum var. karstenii (Pavillard) Sournia, 1966: 1981.

Cell body robust, subtriangular, with slightly convex posterior margin, lacking a notch between the antapical horns, longer than wide. Apical horn very long, somewhat curved at its base. Antapical horns are directed anteriorly. Widest point 
adjacent to the antapical horns. L 410-723 $\mu \mathrm{m}(508.5 \pm 89.7 \mu \mathrm{m}), \mathrm{Wb} 75-93.5 \mu \mathrm{m}$ (85.6 $\pm 4.8 \mu \mathrm{m})$, Wt $220-460 \mu \mathrm{m}(284 \pm 47.9 \mu \mathrm{m}) ; \mathrm{n}=25$.

Affinities: The species is similar to C. contortum, and some authors consider them conspecific. According to Balech (1988), C. karstenii is distinguished from the latter by a more robust and wider cell body and the absence of torsion in the right antapical horn.

Note: Licea et al. (2004) consider this dinoflagellate species one of the 30 most common in the Gulf of Mexico; however, it is rare in Veracruz waters, including NPSAV (Feb., March, Apr., June, July, Nov., Dec.).

References: Karsten, 1907*: pl. 48, fig. 4, 6a-c (as C. arcuatum Gourret, C. arcuatum var. robusta n. var. and C. tripos Schrankii Kofoid); Jörgensen, 1911*: 53, fig. 116, 117; 1920*: 75, fig. 71; Böhm, 1931b*: 26, fig. $23-25$ (C. arcuatum var. robustum); Paulsen, 1931*: 84, fig. 52A-C; Steemann Nielsen, 1934*: 23, fig. 51; Schiller, 1937*: 393, fig. 431a, b; Rampi, 1939*: 306, fig. 18; Kiselev, 1950*: 249, fig. 463, 512; Wood, 1954*: 289, fig. 211a, b; 1968*: 33, fig. 68; Silva, 1956*: 56, pl. 7, fig. 9; Sournia, 1968***: 442, fig. 71, 72, pl. 3, fig. 10 (as C. contortum var. robustum and C. contortum var. Karstenii); Subrahmanyan, 1968*: 42, fig. 67, 68; Steidinger \& Williams, 1970**: 45, pl. 6, fig. 17a, pl. 7, fig. 17b; Hassan, 1976*: 289, fig. 6 (as C. contortum var. karstenii); Taylor, 1976*: 82, pl. 18, fig. 184; Pesantes-Santana, 1978*: 8, pl. 5, fig. 3, 4 (as C. contortum var. karstenü; with an orthographic error in the name of the variety); Trégouboff, 1978*: 116, pl. 25, fig. 16; Dowidar, 1983*: 16, pl. 4, fig. 6; Balech, 1988*: 144, pl. 62, fig. 3, pl. 63, fig. 1, 6; Delgado \& Fortuño, 1991*: fig. 7F; Licea et al., 1995**: 33, pl. 2, fig. 2 (as C. contortum var. karstenii); Konovalova, 1998*: 151, fig. 29 (f. karstenii and f. robustum (Karst.) Jörg.); Yongshui, 2009***: 65, fig. 74, pl. 5, fig. 7 .

22. Ceratium euarcuatum Jörg., 1920 (Pl. 5, Fig. 3; Pl. 12, Fig. 3)

Cell body delicate, subtriangular, longer than it is wide. Posterior margin of the cell is convex, very oblique in relation to the apical horn. Apical horn rather long, slightly curved, positioned centrally. Proximal part of left antapical horn is directed laterally, and that of the right horn is directed laterally-forward; distally they bend continuously and are directed anteriorly, being slightly convergent. Widest point adjacent to the cingulum or to the antapical horns. L 180-285 $\mu \mathrm{m}(226.6 \pm 28.8 \mu \mathrm{m})$, Wb 47.5-56.5 $\mu \mathrm{m}(52.8 \pm 3.0 \mu \mathrm{m})$, Wt 113-250 (153.2 $27.1 \mu \mathrm{m}) ; \mathrm{n}=28$.

Affinities: The species is distinguished from $C$. symetricum by the very oblique posterior margin of the cell. 
Records in the State of Veracruz: Figueroa-Torres, 1990***. Rare in NPSAV (March to Aug., Dec.)

References: Jörgensen, 1920*: 56, fig. 54; Steemann Nielsen, 1934*: 18, fig. 38; Schiller, 1937*: 402, fig. 443; Rampi, 1939*: 306, fig. 30; Graham \& Bronikovsky, 1944*: 28, fig. 15M, N; Wood, 1954*: 294, fig. 220; 1968*: 28, fig. 53; Margalef, 1961b*: 140, fig. 3/7; López, 1966*: fig. 31; Sournia, 1968*: 436, fig. 64, 65; Subrahmanyan, 1968*: 53, fig. 94; Taylor, 1976*: 83, pl. 15, fig. 155, 157, 159; Pesantes-Santana, 1978*: 9, pl. 5, fig. 1, 2; Licea et al., 1995**: 35, pl. 2, fig. 5; Yongshui, 2009* **: 69, fig. 79, pl. 6, fig. 4 .

23. Ceratium tripos (O. F. Müll.) Nitzsch, 1817 (Pl. 5, Fig. 4-6; Pl. 7, Fig. 3; Pl. 8, Fig. 3 and 8; P1. 9, Fig. 8; P1. 12, Fig. 4-6)

Bas.: Cercaria tripos O. F. Müller, 1777: 206; 1786: 136, pl. 19(22).

Cell body subtriangular, its length is equal to or slightly exceeds its width, lacking a notch between the antapical horns. Posterior margin of the cell slightly convex. Apical horn straight, from short to long, positioned subcentrally, slightly inclined to the right. Antapical horns rather short, directed laterally at their bases and then bent anteriorly. Widest point adjacent to the antapical horns. Chains of 2 to 3 cells were observed.

Note: Five varieties and one form have been reported for the Gulf of Mexico (Steidinger et al., 2009). Microgametes 72-77 $\mu \mathrm{m}$ long and 37-40 $\mu \mathrm{m}$ wide, formed by depauperating divisions (sometimes called degenerate forms in the old literature), presumably belonging to C. tripos (see Hoppenrath et al., 2009: fig. 71f-h), were observed twice (Pl. 7, Fig. 3). A teratologic cell with a peculiar apical horn was found.

Records in the State of Veracruz: Avendaño-Sánchez \& Sotomayor-Navarro, 1982; Figueroa-Torres, 1990* **; Estradas-Romero, 2004 (as C. pentagonum var. atlanticus); Tejeda-Hernández, 2005** (as C. tripos tripodioides; the specimen in the photograph does not correspond to var. tripodoides). Very common in NPSAV, throughout the year.

References: Ostenfeld, 1903*: 583, fig. 132-134 (two forms are illustrated); Paulsen, 1907*: 21, fig. 30, 31 (two forms are illustrated); 1908*: 77, fig. 102-107; 1931*: 78, fig. 47A-F; Jörgensen, 1911*: 35, fig. 1, 2, 65-79; 1920*: 46, fig. 33-39 (C. tripos), 40-53 (C. pulchellum); Lebour, 1925*: 148, fig. 32, 33; Wailes, 1928*: 5, pl. 1, fig. 4, pl. 3, fig. 1 (as C. tripos var. atlantica); Böhm, 1931a*: 356, fig. 7-10, 33-35 (six taxa are illustrated including three new forms); 1931b*: 15, fig. 12-16 (C. tripos and 
C. pulchellum), 38 (C. pulchellum var. indicum n. var.); Steemann Nielsen, 1934*: 17, fig. 32, 33; Schiller, 1937*: 382, fig. 383, 385; Schiller, 1937*: 401, fig. 441a-d; Graham \& Bronikovsky, 1944*: 25, fig. 13E-N, 14B-F; Kiselev, 1950*: 246, fig. 428, 431, 432, 440, 442; Kato, 1957*: 15, pl. 4, fig. 12a, b, 13a, b (C. tripos and C. tripos f. neglecta (Ostenfeld) Paulsen); Curl, 1959*: 306, fig. 121, 123 (C. tripos var. atlanticum Ostenfeld and C. pulchellum Schroeder); Margalef, 1961a*: 81, fig. 26j, pl. 6, 7; López, 1966***: fig. 33-36, photo 2(1-3) (four infraspecific taxa are illustrated); Subrahmanyan, 1968*: 35, fig. 59, pl. 3, fig. 17, 18; Wood, 1968*: 41, fig. 92, 93 (also as C. tripos var. pulchellum (Schröder) nov. comb.); Hermosilla, 1973*: 65, pl. 33, fig. 5; Drebes, 1974**: 148, fig. 130; Hassan, 1976*: 287, fig. 2 (C. tripos var. atlanticum); Taylor, 1976*: 88, pl. 14, fig. 147, 149-151, pl. 16, fig. 168-170; Trégouboff, 1978*: 116, pl. 25, fig. 14A, B; Burns \& Mitchell, 1982***: 64, fig. 17-22 (three infraspecific taxa are figured); Dodge, 1982*: 234, fig. 30A-D; Dowidar, 1983*: 13, pl. 2, fig. 9; Balech, 1988*: 138, pl. 58, fig. 1-7, pl. 59, fig. 1-6, pl. 60, fig. 1, 2; Konovalova et al., 1989****: 136, fig. 51(1), pl. 23, fig. 6-8 (var. balticum Schütt); Steidinger \& Williams, 1970**: 47, pl. 15, fig. 40 (?) (as Ceratium sp.); Delgado \& Fortuño, 1991****: fig. 7C; 6, pl. 3, fig. c, d; Licea et al., 1995***: 48, pl. 5, fig. 5a, b, 7, pl. 20, fig. 4 (the taxon given as C. tripos var. ponticum Jörgensen in pl. 5, fig. 6a-c, is C. balechii; see the note to C. dens); 2004**: fig. 22; Wiktor \& Okolodkov, 1995*: 44, fig. 14a, b; Steidinger \& Tangen, 1997*: 478, pl. 26; Konovalova, 1998****: 142, fig. 30(2, 4-6, 8), 31(5), pl. 13, fig. 3, 4 (five infraspecific taxa are illustrated); Bérard-Therriault et al., 1999**: 165, pl. 82b (C. tripos var. atlanticum Ostenfeld, 1903); Avancini et al., 2006***: 303, fig. A, B; 295, fig. A, B (C. pulchellum); Hoppenrath et al., 2009*****: 175, fig. 71a-1; Yongshui, 2009******: 77, fig. 89-92, pl. 7, fig. 3-6, pl. 18, fig. 1-3 (four infraspecific taxa are illustrated).

var. tripos (Pl. 5, Fig. 4; Pl. 8, Fig. 8; Pl. 12, Fig. 4)

Cell body is as long as wide, without a depression between the posterior margin of the cell body and the right antapical horn. L 120-248 $\mu \mathrm{m}$ (192.5 $\pm 42.7 \mu \mathrm{m}), \mathrm{Wb}$ 66-83 $\mu \mathrm{m}(74.2 \pm 5.0 \mu \mathrm{m})$, Wt 150-200 $\mu \mathrm{m}(168.6 \pm 13.0 \mu \mathrm{m}) ; \mathrm{n}=25$.

Records in the State of Veracruz: Ochoa-Figueroa, 1978 (as Ceratium tripos); Hernández-Mendiola, 1988 (as C. tripos); Suchil-Vilchis, 1990* (as C. tripos); Zamudio-Resendiz, 1998 (var. tripos and var. pulchellum).

References: Balech, 1988*: 139, fig. 1-6; Yongshui, 2009***: 77, fig. 89, pl. 7, fig. 3 .

var. breve Ostenf. et J. Schmidt, 1901 (P1. 5, Fig. 5; P1. 12, Fig. 5) 
Syn.: Ceratium breve (Ostenf. et J. Schmidt) Schröder, 1906: 358.

Cell body is as long as wide, larger than in other varieties, without a depression between the posterior margin of the cell body and the right antapical horn. L $125 \mu \mathrm{m}$, Wb 83-88 $\mu \mathrm{m}(85.3 \pm 3.2 \mu \mathrm{m})$, Wt 145-175 $\mu \mathrm{m}(160 \pm 21.2 \mu \mathrm{m}) ; \mathrm{n}=2$.

Records in the State of Veracruz: Avendaño-Sánchez \& Sotomayor-Navarro, 1982; Figueroa-Torres, 1990***; Zamudio-Resendiz, 1998; Aquino-Cruz, 2002**: fig. 2, non pl.1, fig. 2 (a very schematic line drawing in pl. 1 is more similar to C. symetricum var. symetricum than to C. tripos var. breve); Tejeda-Hernández, 2005**.

References: Jörgensen, 1911*: 40, fig. 84; Böhm, 1931b*: 18, fig. 17, 18; Steemann Nielsen, 1934*: 18, fig. 35, 36; Schiller, 1937*: 391, fig. 429a, b; Graham \& Bronikovsky, 1944*: 27, fig. 14G-P; Wood, 1954*: 288, fig. 209a, b; 1968*: 24, fig. 42; Schiller, 1937*: 401, fig. 441a-d; Sournia, 1968***: 416, fig. 40-45, pl. 2, fig. 7 (seven infraspecific taxa are indicated); Subrahmanyan, 1968*: 40, fig. 62, 63, pl. 3, fig. 13-15; Steidinger \& Williams, 1970**: 47, pl. 14, fig. 37a, pl. 15, fig. 38a, b (var. atlanticum and var. ponticum); Hassan, 1976*: 287, fig. 3, 4 (C. breve var. parallelum); Taylor, 1976*: 80, pl. 14, fig. 141, 142, 146; Pesantes-Santana, 1978*: 7, pl. 3, fig. 3, 4; Burns \& Mitchell, 1982***: 60, fig. 6-10; Dowidar, 1983*: 13, pl. 2, fig. 10, pl. 3, fig. 12; Balech, 1988*: 140, pl. 60, fig. 1, 2; Hernández-Becerril, 1988**: 188, pl. 1, fig. 6; Konovalova, 1998*: 146, fig. 30(5); Licea et al., 2004***: fig. 9; Yongshui, 2009******: 61, fig. 69, pl. 5, fig. 4, pl. 15, fig. 3 (as C. breve var. breve).

f. tripodoides Jörg., 1920 emend. Paulsen, 1931 (Pl. 5, Fig. 6; Pl. 8, Fig. 3; Pl. 12, Fig. 6)

Syn.: Ceratium tripodoides (Jörg.) Ostenf. et J. Schmidt, 1901: 15, fig. 28; Ceratium pulchellum f. tripodoides Jörg., 1920: 50, fig. 41, 42, 45; Ceratium tripos var. tripodoides (Jörg.) Paulsen, 1931: 78, fig. 47.

Cell body slightly longer than wide, with a shallow depression between the posterior margin of the cell body and the right antapical horn. L 138-346 $\mu \mathrm{m}$ (276.1 \pm 40.3 $\mu \mathrm{m})$, Wb 60-71 $\mu \mathrm{m}(65.5 \pm 4.5 \mu \mathrm{m})$, Wt 145-203 $\mu \mathrm{m}(172.9 \pm 15.0 \mu \mathrm{m}) ; \mathrm{n}=21$.

Note: This variety is reported here for the first time for the Gulf of Mexico. Var. tripodoides and var. atlanticum (Ostenf.) Paulsen are very similar (Sournia, 1968: 419), and are likely to be synonyms.

References: Paulsen, 1931*: 78, fig. 47A-F; López, 1966*: fig. 34; Pesantes-Santana, 1978*: 18, fig. pl. 12, fig. 5 (as Ceratium tripos var. tripoides); Konovalova, 1998*: 144, fig. 30(4); Yongshui, 2009****: 81, fig. 93, pl. 18, fig. 3 (as C. tripodioides). 


\section{Ceratium azoricum Cleve, 1900 (P1. 5, Fig. 7; P1. 12, Fig. 7)}

Cell body subglobular, with convex posterior margin, lacking a notch between the antapical horns. Apical horn very short, positioned centrally. Antapical horns relatively short, continuously curved and directed anteriorly. Right antapical horn is positioned very close to the cell body. Widest point adjacent to the antapi-

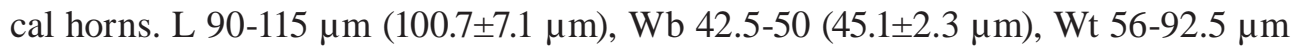
$(77.0 \pm 9.4 \mu \mathrm{m}) ; \mathrm{n}=21$.

Records in the State of Veracruz: Figueroa-Torres, 1990*. Rare to common in NPSAV (Feb., March, July, Aug., Nov., Dec.).

References: Karsten, 1907*: pl. 48, fig. 1a, b; Paulsen, 1908*: 76, fig. 99; Jörgensen, 1911*: 47, fig. 97, 98; 1920*: 69, fig. 66; Lebour, 1925*: 151, fig. 48; Wailes, 1928*: 5, pl. 1, fig. 3; Steemann Nielsen, 1934*: 20. fig. 43; Schiller, 1937*: 406, fig. 447; Rampi, 1939*: 307, fig. 25; Graham \& Bronikovsky, 1944*: 30, fig. 16M-P; Kiselev, 1950*: 252, fig. 413; Wood, 1954*: 295, fig. 222a, b; López, 1966*: fig. 26; Sournia, 1968*: 435, fig. 58; Subrahmanyan, 1968*: 56, fig. 102; Hermosilla, 1973*: 67, pl. 36, fig. 1-4; Hassan, 1976*: 289, fig. 5; Taylor, 1976*: 79, pl. 15, fig. 160; Pesantes-Santana, 1978*: 7, pl. 2, fig. 4, 5; Trégouboff, 1978*: 115, pl. 26, fig. 6; Burns \& Mitchell, 1982***: 57, fig. 5 (the specimens illustrated in fig. 2 and 3 as C. arietinum most likely belong to C. azoricum); Dodge, 1982*: 232, fig. 29F; Dowidar, 1983*: 14, pl. 4, fig. 7; Balech, 1988*: 137, pl. 57, fig. 6; Licea et al., 1995**: 30, pl. 1, fig. 4; Konovalova, 1998*: 142, fig. 29(13); Yongshui, 2009***: 60 , fig. 68 , pl. 5 , fig. 3 .

25. Ceratium arietinum Cleve, 1900 var. gracilentum (Jörg.) Sournia, 1966 (Pl. 5, Fig. 8; P1. 12, Fig. 8)

Cell body rather delicate, with notably convex posterior margin, lacking a notch between the antapical horns. Apical horn short or moderately long, slightly curved at its base and distally straight, emerging from the left half of the cell body. Antapical horns are positioned at subequal distance from the cell body. Their proximal parts are directed laterally, distally they bend continuously, forming a semicircle. The distal part of the right antapical horn is perpendicular to the apical horn. Widest region adjacent to the antapical horns, also occupying the distal half of the cell body on the left side. L 140-243 $\mu \mathrm{m}$ (182.2 $\pm 45.2 \mu \mathrm{m}), \mathrm{Wb} 52.5-55 \mu \mathrm{m}(54.2 \pm 1.3$ $\mu \mathrm{m})$, Wt 140-163 $\mu \mathrm{m}(152 \pm 9.5 \mu \mathrm{m}) ; \mathrm{n}=6$.

Affinities: C. declinatum (see the notes to C. declinatum). 
Note: The species has been repeatedly reported for the Gulf of Mexico (Steidinger et al., 2009).

Records in the State of Veracruz: Figueroa-Torres, 1990***; Zamudio-Resendiz, 1998. Extremely rare in NPSAV (Jan., March, May, July, Aug., Dec.).

References: Karsten, 1907*: pl. 48, fig. 3; Jörgensen, 1911*: 48, fig. 102-105; 1920*: 62, fig. 60-62; Steemann Nielsen, 1934*: 21, fig. 45; Schiller, 1937*: 403, fig. 414; Rampi, 1939*: 307, fig. 28; Graham \& Bronikovsky, 1944*: 31, fig. 16A-K; Kiselev, 1950*: 252, fig. 420; Wood, 1954*: 294, fig. 221a; 1968*: 23, fig. 37; Kato, 1957*: 16, pl. 6, fig. 21, 22 (including C. bucephalum var. heterocamptum Jörgensen); López, 1966*: fig. 27; Sournia, 1968*: 429, fig. 51, 52, 54 (three varieties are illustrated); Subrahmanyan, 1968*: 54, fig. 95-97; Taylor, 1976*: 78, pl. 16, fig. 162, 165; Trégouboff, 1978*: 115, pl. 26, fig. 4; Burns \& Mitchell, 1982***: 57, fig. 4, non 2, 3 (the specimens illustrated in fig. 2 and 3 are likely misidentifications, and they correspond well to C. azoricum); Dowidar, 1983*: 14, pl. 3, fig. 10; Dodge, 1985***: 93; Balech, 1988*: 143, pl. 61, fig. 4-6; Delgado \& Fortuño, 1991***: fig. 6L; 5, pl. 8, fig. a, b, pl. 9, fig. d; Licea et al., 1995***: pl. 1, fig. 3, pl. 17, fig. 5; Wiktor \& Okolodkov, 1995*: 32, fig. 8a, b; Steidinger \& Tangen, 1997*: 471, pl. 27; Konovalova, 1998*: 149, fig. 30(10, 11) (f. arietinum and f. gracilentum Jörg.); Hoppenrath et al., 2009*****: 175, fig. 71m-p; Yongshui, 2009***: 59, 64, fig. 66, 72 (including C. bucephalum var. heterocamptum), pl. 5, fig. 2.

26. Ceratium symetricum Pavillard, 1905 (Pl. 5, Fig. 9; Pl. 12, Fig. 9) Syn.: Ceratium gracile (Gourret) Jörg., 1911: 44, pl. 5, fig. 92-95.

Cell body with convex sides, sometimes slightly inflated on the left side, with notably convex posterior margin, lacking a notch between the antapical horns, slightly longer than wide. Apical horn rather short and slightly curved, positioned centrally. Antapical horns relatively long, continuously curved and directed anteriorly, positioned at about equal distance from the cell body. Widest point adjacent to the cingulum and the antapical horns. L 140-200 $\mu \mathrm{m}(169.2 \pm 13.3 \mu \mathrm{m}), \mathrm{Wb} 42.5-56$ $\mu \mathrm{m}(51.0 \pm 4.8 \mu \mathrm{m})$, Wt $125-160 \mu \mathrm{m}(138.2 \pm 13.2 \mu \mathrm{m}) ; \mathrm{n}=13$.

Note: Two varieties of this species have been reported for the Gulf of Mexico (Steidinger et al., 2009).

Records in the State of Veracruz: Avendaño-Sánchez \& Sotomayor-Navarro, 1982; Figueroa-Torres, 1990*** (var. coarctatum (Pavillard) Graham et Bronikovsky); Zamudio-Resendiz, 1998. Extremely rare in NPSAV (Feb., March, May to Aug., Dec.).

References: Karsten, 1907*: pl. 48, fig. 7a, b (as C. tripos coarctatum Pavi1lard); Böhm, 1931a*: 358, fig. 11 (as C. gracile); Paulsen, 1931*: 82, fig. 49; Steemann 
Nielsen, 1934*: 19, fig. 40, 41; Schiller, 1937*: 401, fig. 441a-d; Rampi, 1939*: 306, fig. 27; 1951*: 6, fig. 6 (a teratologic specimen); Graham \& Bronikovsky, 1944*: 29, fig. 15H-L; López, 1966*: fig. 29, 30 (C. symmetricum and C. symmetricum coarctatum); Sournia, 1968*: 432, fig. 55-57 (three varieties are illustrated); Subrahmanyan, 1968*: 51, fig. 89-92; Wood, 1968*: 40, fig. 89; Steidinger \& Williams, 1970**: 47, pl. 13, fig. 34 (var. coarctatum); Taylor, 1976*: 87, pl. 15, fig. 152-154, 156 (three varieties are illustrated); Trégouboff, 1978*: 115, pl. 26, fig. 3; Dowidar, 1983*: 14, pl. 4, fig. 5, pl. 6, fig. 1; Balech, 1988*: 143, pl. 61, fig. 7, 9; Delgado \& Fortuño, 1991* ***: fig. 7A, G; 6, pl. 5, fig. a; Licea et al., 1995***: 47, pl. 5, fig. 1, 2, pl. 20, fig. 3; Steidinger \& Tangen, 1997*: 478, pl. 28; Konovalova, 1998*: 150, fig. 30(1); Avancini et al., 2006***: 299, fig. A-C; Yongshui, 2009******: 75, fig. 87, 88, pl. 7, fig. 1, 2, pl. 17, fig. 4 (var. coarctatum and var. orthoceras).

27a. Ceratium declinatum (G. Karst.) Jörg. var. angusticornum (Peters) F. J. R. Taylor, 1976 (Pl. 6, Fig. 1; Pl. 12, Fig. 10)

Syn.: Ceratium declinatum subsp. angusticornum Peters, 1934: 43, pl. 4, fig. 23b (invalid, see Sournia, 1973); Ceratium declinatum subsp. angusticornum (Peters) Graham et Bronikovsky, 1944: 32, fig. 17A-C (invalid, see Sournia, 1973).

This variety is distinguished from $\mathrm{f}$. normale by the direction of the right antapical horn, the distal part of which forms an angle of about $90^{\circ}$ with its proximal part, so that the distal parts of both antapical horns are slightly convergent. L 148-183 $\mu \mathrm{m}$ (161.6 $\pm 13.7 \mu \mathrm{m})$, Wb 37.5-41.5 $\mu \mathrm{m}(39.1 \pm 1.7 \mu \mathrm{m})$, Wt 70-89 $\mu \mathrm{m}(82.0 \pm 7.4 \mu \mathrm{m}) ; \mathrm{n}=5$.

A new record for the state of Veracruz. Extremely rare in NPSAV (Feb., March, Dec.).

Affinities: The species is morphologically similar to C. arietinum; however, the former has a subpentagonal cell body (the latter has a subtriangular cell body) and a more curved right antapical horn, especially in its distal part.

References: Taylor, 1976*: 83, pl. 16, fig. 164, 167; Yongshui, 2009*: 68, fig. 78.

27b. Ceratium declinatum (G. Karst.) Jörg., 1911 f. normale Jörg., 1911 (Pl. 6, Fig. 2; Pl. 13, Fig. 1)

Bas.: Ceratium tripos declinatum G. Karst., 1907: 406, pl. 48, fig. 2.

Cell body delicate, subtriangular, longer than it is wide. Posterior margin of the cell is generally convex, almost flat near the right antapical horn. Epitheca is 
asymmetrically convex, much more on the right side than near the left one. Apical horn moderately long, slightly curved at its base and distally it is straight, strongly shifted to the left. Proximal parts of the antapical horns are directed laterally; distally they bend continuously and are directed anteriorly, being slightly divergent. Widest point adjacent to the cingulum or to the antapical horns. L 158-290 $\mu \mathrm{m}$ (177.7 $\pm 27.0 \mu \mathrm{m})$, Wb 30-45 $\mu \mathrm{m}(39.4 \pm 3.1 \mu \mathrm{m})$, Wt 60-138 $\mu \mathrm{m}(111.5 \pm 20.0 \mu \mathrm{m})$; $\mathrm{n}=24$.

Affinities: The taxon is very similar in shape to C. tripos var. tripodoides, but it is considerably smaller. The apical horn in C. declinatum is positioned markedly closer to the right side of the epitheca, whereas in C. tripos var. tripodoides it is centrally inserted. Also, it is similar to C. arietinum; however, C. declinatum has a more convex right side of the cell body.

Records in the State of Veracruz: Legaría-Moreno, 2003. Rare in NPSAV (Feb., March, May, June, Dec.).

References: Karsten, 1907*: pl. 48, fig. 2a, b; Jörgensen, 1911*: 42, fig. 87-89; 1920*: 66, fig. 63-65; Paulsen, 1931*: 83, fig. 50 (as C. declinatum Karsten var. majus Jörgensen); Steemann Nielsen, 1934*: 22, fig. 46, 47; Schiller, 1937*: 404, fig. 445; Rampi, 1939*: 307, fig. 26; 1951*: 6, fig. 6 (a teratologic specimen); Graham \& Bronikovsky, 1944*: 32, fig. 16Q-T, 17A-C; Kiselev, 1950*: 249, fig. 425; López, 1966*: fig. 32; Wood, 1954*: 293, fig. 218a-c; 1968*: 27, fig. 50; Sournia, 1968***: 438, fig. 66, pl. 2, fig. 8 (six infraspecific taxa are distinguished); Steidinger et al., 1967**: pl. 6, fig. b (as C. declinatum); Subrahmanyan, 1968*: 54, fig. 98-101, pl. 4, fig. 20; Steidinger \& Williams, 1970**: 45, pl. 7, fig. 18; Hermosilla, 1973*: 66, pl. 34, fig. 1-3; Taylor, 1976*: 82, pl. 16, fig. 163, 164, 166, 167; Pesantes-Santana, 1978*: 9, pl. 4, fig. 4, 5; Trégouboff, 1978*: 115, pl. 26, fig. 5; Licea et al., 1995***: 34, non fig. 3 (judging from the centrally positioned apical horn, most likely C. tripos var. tripodoides is illustrated); Steidinger \& Tangen, 1997*: 472, pl. 26; Konovalova, 1998*: 149, fig. 30(9); Avancini et al., 2006***: 285, fig. A-C.

\section{Ceratium carriense Gourret, 1883 (P1. 6, Fig. 3; Pl. 13, Fig. 2)}

Cell body robust, subtrapezoidal. Posterior margin of the cell is flat and oblique, with a noticeable membrane near the left antapical horn. Epitheca is asymmetrically convex. Apical horn very long, straight or almost straight, centrally positioned. Antapical horns are very long. Proximal parts of the antapical horns are directed laterally-backward; distally they bend rather abruptly and are directed anteriorlylaterally or almost laterally, being strongly divergent. Widest point adjacent to the 
antapical horns. L 420-770 $\mu \mathrm{m}(613.4 \pm 116.4 \mu \mathrm{m}), \mathrm{Wb} 62-75 \mu \mathrm{m}(69.7 \pm 3.5 \mu \mathrm{m}), \mathrm{Wt}$ 890-1415 $\mu \mathrm{m}(1129 \pm 150.6 \mu \mathrm{m}) ; \mathrm{n}=20$.

Records in the State of Veracruz: Figueroa-Torres, 1990***. Rare in NPSAV (March, May, June).

References: Karsten, 1907*: pl. 49, fig. 17, 18 (as C. tripos volans var. tenuissima Kofoid and var. elegans Br. Schröder); Jörgensen, 1911*: 68, fig. 147a, b; 1920*: 89, fig. 81, 82; Pavillard, 1916*: 17, pl. 1, fig. 4 (C. carriense var. volans); Paulsen, 1931*: 90, fig. 57A-D; Steemann Nielsen, 1934*: 26, fig. 64; Schiller, 1937*: 425, fig. 464-466; Rampi, 1939*: 310, fig. 35, 37 (two forms are illustrated); Graham \& Bronikovsky, 1944*: 39, fig. 22A; Wood, 1954*: 308, fig. 236a, b; 1968*: 25, fig. 46; Silva, 1956*: 66, pl. 9, fig. 5-8; Curl, 1959*: 306, fig. 122 (mistakingly identified as C. trichoceros, judging from the antapical horns); López, 1966*: fig. 47-49 (C. carriense and C. carriense volans); Subrahmanyan, 1968*: 77, fig. 143, 144, pl. 7, fig. 36; Steidinger \& Williams, 1970**: 44, pl. 5, fig. 14a, b, 15a, b (C. carriense and C. carriense var. volans); Hassan, 1976*: 291, fig. 18a, b (var. carriense); Taylor, 1976*: 69, pl. 20, fig. 200; Pesantes-Santana, 1978*: 8, pl. 3, fig. 5; Trégouboff, 1978*: 116, pl. 26, fig. 16; Dodge, 1982*: 236, fig. 31G; Hernández-Becerril, 1988**: 189, l'am. 1, fig. 4; Licea et al., 1995**: 32, pl. 1, fig. 9; Steidinger \& Tangen, 1997*: 471, pl. 29; Konovalova, 1998*: 156, fig. 31(6, 7) (var. carriense and var. volans (Cl.) Jörg).

29. Ceratium macroceros (Ehrenb.) Vanhöffen, 1897 var. gallicum (Kof.) Sournia, 1966 (Pl. 6, Fig. 4; Pl. 8, Fig. 4; Pl. 13, Fig. 3)

Bas.: Peridinium macroceros Ehrenb., 1840: 201.

Syn.: Ceratium gallicum Kofoid, 1907 (Univ. Calif. Publ. Zool. 3): 302, pl. 24, fig. 10-12.

Cell body rather delicate, subquadrangular, with nearly flat posterior margin. Apical horn very long, straight or almost straight, sometimes slightly curved in its proximal part. Proximal parts of the antapical horns are directed posteriorly, forming a deep notch between them; distally they bend rather abruptly and are directed anteriorly but generally diverge notably. Posterior membrane is well developed. Widest point adjacent to the antapical horns. L $260-470 \mu \mathrm{m}(392 \pm 70.5 \mu \mathrm{m}), \mathrm{Wb}$ 47.5-55 $\mu \mathrm{m}(50.4 \pm 2.9 \mu \mathrm{m})$, Wt $220-400 \mu \mathrm{m}(329.9 \pm 45.7 \mu \mathrm{m}) ; \mathrm{n}=21$.

Note: Two varieties of this species have been reported for the Gulf of Mexico (Steidinger et al., 2009).

Records in the State of Veracruz: Ochoa-Figueroa, 1978; Avendaño-Sánchez \& Sotomayor-Navarro, 1982; Figueroa-Torres, 1990*; Suchil-Vilchis, 1990; 
Zamudio-Resendiz, 1998; Estradas-Romero, 2004. Common in NPSAV, probably, throughout the year.

References: Ostenfeld \& Schmidt, 1901: 167, fig. 19; Karsten, 1907*: pl. 49, fig. 26-28; Paulsen, 1908*: 81, fig. 109; 1931*: 87, fig. 54A-C (as C. macroceros subsp. gallicum (Kofoid) Jörgensen); Jörgensen, 1911*: 63, fig. 132a, b, 133; 1920*: 83, fig. 77; Wailes, 1928*: 5, pl. 11, fig. 17, 18, non 16 (the specimens illustrated in fig. 17 and 18 are likely misidentifications, and they correspond well to C. horridum); Böhm, 1931b*: 38, fig. 35a; Steemann Nielsen, 1934*: 25, fig. 59; Schiller, 1937*: 428, fig. 468; Rampi, 1939*: 310, fig. 42; Graham \& Bronikovsky, 1944*: 37, fig. 21B-F; Kiselev, 1950*: 254, fig. 422; Kato, 1957*: 18, pl. 7, fig. 23; Margalef, 1961a*: 81, pl. 7 (as C. massiliense var. gallicum (Kof.) Jörg.); López, 1966*: fig. 16; Sournia, 1968*: 460, fig. 83-85 (var. macroceros and var. gallicum); Subrahmanyan, 1968*: 79, fig. 149, 150, pl. 4, fig. 24, pl. 5, fig. 25, 26, pl. 6, fig. 29, 30; Wood, 1968*: 30, fig. 59 (as Ceratium gallicum Kofoid); 36, fig. 77; Steidinger \& Williams, 1970**: 46, pl. 11, fig. 29a, b; Drebes, 1974**: 149, fig. 132; Taylor, 1976*: 72, pl. 20, fig. 198, 199, pl. 22, fig. 218; Pesantes-Santana, 1978*: 15, pl. 11, fig. 3; Trégouboff, 1978*: 116, pl. 26, fig. 17; Tester \& Steidinger, 1979**: 29, pl. 11, fig. 68; Dodge, 1982*: 235, fig. 31 A; Dowidar, 1983*: 17, pl. 7, fig. 5; Balech, 1988*: 146, pl. 64, fig. 1, 4; Konovalova et al., 1989***: 135, pl. 23, fig. 3; Licea et al., 1995**: 42, pl. 4, fig. 1, 2; 2004**: fig. 14; Wiktor \& Okolodkov, 1995*: 42, fig. 13a, b; Konovalova, 1998***: 153, fig. 32(4, 5) (var. macroceros and var. gallicum (Kof.) Jörg.); Alonso-Rodríguez et al., 2008**: 129; Hoppenrath et al., 2009**: 178, fig. 72i, j; Yongshui, 2009*: 41, fig. 47.

30. Ceratium horridum (Cleve) Gran, 1902 (Pl. 6, Fig. 5-7; Pl. 13, Fig. 4 and 5)

Bas.: Ceratium tripos var. horridum Cleve, 1897: 302, fig. 2.

Syn.: Ceratium tenue (Ostenf. et J. Schmidt) Jörg., 1911 (Intern. Rev. d. ges. Hydrob. u. Hydrog. 4, Suppl.-Heft, 1): 77, fig. 163; C. intermedium (Jörg.) Jörg., 1911 (Intern. Rev. d. ges. Hydrob. u. Hydrog. 4, Suppl.-Heft, 1): 83, fig. 174-176; C. claviger Kof., 1907 (Bull. Mus. Comp. Zool. Harv. Coll. 50, 6): 170, pl. 4, fig. 27.

Cell body relatively robust. Posterior margin of the cell oblique. Apical horn rather long, almost straight, positioned centrally. Proximal parts of the antapical horns are directed laterally, lacking a notch between them; distally they bend continuously and are directed anteriorly, being slightly parallel to each other. Widest point adjacent to the antapical horns.

Note: Three varieties have been reported for the Gulf of Mexico (Steidinger et al., 2009). The taxonomy of the species is extremely complicated. Numerous in- 
fraspecific taxa of $C$. horridum are known. Furthermore, there is no agreement as to whether $C$. tenue is synonymous to $C$. horridum or a different species.

Records in the State of Veracruz: Avendaño-Sánchez \& Sotomayor-Navarro, 1982; Figueroa-Torres, 1990***; Estradas-Romero, 2004. Rare to common in NPSAV (March, Oct., Dec.).

References: Ostenfeld, 1903*: 584, fig. 136-139; Karsten, 1907*: pl. 48, fig. 16 (as C. tripos buceros O. Zacharias), pl. 49, fig. 19-21 (as C. tripos inclinatum Kofoid and C. tripos inclinatum var. aequatorialis Br. Schröder); Pavillard, 1916*: 18, pl. 1, fig. 5, 6; Jörgensen, 1920*: 96, fig. 86-92; Lebour, 1925*: 155, pl. 34, fig. 2; Wailes, 1928*: 5, pl. 1, fig. 1; Böhm, 1931a*: 365, fig. 20 (as C. horridum var. tenue); 1931b*: 41, fig. 36a-g; Schiller, 1937*: 413, fig. 455a-c, 456; Graham \& Bronikovsky, 1944*: 42, fig. 23I-L; Kiselev, 1950*: 253, fig. 430; Wood, 1954*: 300, fig. 230a, b, 231a-i; 1968*: 32, fig. 65; Kato, 1957*: 17, pl. 5, fig. 14; Curl, 1959*: 306, fig. 118 (the specimen given as C. macroceros is likely a misidentification, and the figure satisfactorily corresponds to C. horridum); López, 1966*: fig. 42, 43; Sournia, 1968***: 474, fig. 91-95 pl. 3, fig. 12 (three infraspecific taxa are distinguished); Subrahmanyan, 1968*: 63, fig. 113-128; Drebes, 1974**: 145, fig. 129a; Hassan, 1976*: 291, fig. 14 (C. horridum var. molle); Taylor, 1976*: 71, pl. 20, fig. 202, pl. 21, fig. 203-208, 211, 212; Pesantes-Santana, 1978*: 13, pl. 11, fig. 4; Burns \& Mitchell, 1982***: 60, fig. 11; Dowidar, 1983*: 19, pl. 6, fig. 6, pl. 7, fig. 2; Balech, 1988*: 148, pl. 65, fig. 3-9; Delgado \& Fortuño, 1991***: 6, pl. 1, fig. c, d; Wiktor \& Okolodkov, 1995*: 38, fig. 11a, b; Licea et al., 1995***: 39, pl. 3, fig. 3a, b, 4, pl. 18, fig. 11; Steidinger \& Tangen, 1997*: 474, pl. 28; Konovalova, 1998*: 158, fig. 31(2-4) (three infraspecific taxa are illustrated); Bérard-Therriault et al., 1999**: 164, pl. 83d; Hoppenrath et al., 2009**: 178, fig. 72a-g; Yongshui, 2009**: pl. 3, fig. 1-4.

var. buceros (Zacharias) Sournia, 1966 (Pl. 6, Fig. 5; Pl. 13, Fig. 5)

Cells with slender, usually delicate and thin, markedly divergent antapical horns. Antapical horns are much shorter than the apical one (3/5-2/3 of the apical horn length). The posterior margin of the cell is not dentate. L 160-270 $\mu \mathrm{m}(211.9 \pm 30.1$ $\mu \mathrm{m}), \mathrm{Wb} 34-40 \mu \mathrm{m}(37.8 \pm 1.8 \mu \mathrm{m}), 130-240 \mu \mathrm{m}(158.6 \pm 24.8 \mu \mathrm{m}) ; \mathrm{n}=21$.

Records in the State of Veracruz: Figueroa-Torres, 1990*** (as C. buceros var. tenue).

References: Karsten, 1907*: pl. 48, fig. 16 (as C. tripos buceros O. Zacharias); Rampi, 1942*: 226, fig. 9; Steidinger \& Williams, 1970**: 44, pl. 4, fig. 12 (as C. 
buceros f. tenue); Trégouboff, 1978*: 116, pl. 26, fig. 20 (as C. buceros f. tenue (Ost. et Schm.) Schill.).

var. molle (Kof.) Jörg., 1911 (Pl. 6, Fig. 6 and 7; Pl. 13, Fig. 4)

Cell with coarse parallel, slightly divergent or slightly convergent antapical horns. All horns are subequal in length (at least in our samples). The posterior margin of the cell is often markedly dentate.

L 157-470 $\mu \mathrm{m}(241.9 \pm 67.9 \mu \mathrm{m}), \mathrm{Wb} 30-48 \mu \mathrm{m}(43.2 \pm 3.6 \mu \mathrm{m}), \mathrm{Wt} 120-200 \mu \mathrm{m}$ $(163.7 \pm 18.4 \mu \mathrm{m}) ; \mathrm{n}=24$.

References: Jörgensen, 1920*: 96, fig. 87; Rampi, 1942*: 226, fig. 17; Graham \& Bronikovsky, 1944*: 42, fig. 23I, K, 25D; Hassan, 1976*: 291, fig. 14; Taylor, 1976*: 71, pl. 21, fig. 208; Balech, 1988*: 149, pl. 65, fig. 8, 9; Konovalova, 1998*: 158, fig. 31, fig. 4; Yongshui, 2009**: pl. 3, fig. 2.

31. Ceratium massiliense (Gourret) Jörg., 1911 var. armatum (G. Karst.) Jörg., 1911 (Pl. 6, Fig. 8; Pl. 7, Fig. 2; Pl. 8, Fig. 5; Pl. 9, Fig. 9; Pl. 13, Fig. 6)

Bas.: Ceratium tripos var. massiliense Gourret, 1883: 27, pl. 1, fig. 2.

Cell body robust, subtriangular, with nearly flat posterior margin. Apical horn very long, straight. The proximal part of the left antapical horn is directed posteriorly and that of the right horn laterally-posteriorly. A notch between the antapical horns is notable only near the right horn. Posterior membrane is well developed. Widest point adjacent to the antapical horns. L $285-650 \mu \mathrm{m}(464.8 \pm 105.4 \mu \mathrm{m}), \mathrm{Wb}$ 67.5-78 $\mu \mathrm{m}(71.6 \pm 3.3 \mu \mathrm{m}), \mathrm{Wt} 280-540 \mu \mathrm{m}(411.9 \pm 76.1 \mu \mathrm{m}) ; \mathrm{n}=21$. Chains of 2 cells were observed.

Note: This species has repeatedly been reported for the Gulf of Mexico although without distinguishing infraspecific forms (Steidinger et al., 2009). A teratologic specimen, with the left antapical horn twisted and directed backward, was observed (Pl. 7, Fig. 2). It corresponds well to C. recurvatum Schröder figured by Taylor (1976: 74, pl. 21, fig. 209) who commented that "perhaps this taxon is a conglomerate of several species exhibiting a particular type of horn aberration". Also, it is similar to C. recurvatum in Yongshui (2009: 47, fig. 55, pl. 3, fig. 6) and to C. deflexum (Kof.) Jörg. in Schiller (1937: 428, fig. 467b).

Records in the State of Veracruz: Ochoa-Figueroa, 1978; Avendaño-Sánchez \& Sotomayor-Navarro, 1982; Figueroa-Torres, 1990***. Common in NPSAV throughout the year. 
References: Jörgensen, 1911*: 66, fig. 140-142; 1920*: 85, fig. 78-80; Böhm, 1931a*: 362, fig. 16 (C. massiliense f. protuberans (Karsten), C. massilense f. ellipticum n. f. and C. massiliense $\alpha$-macroceroides); 1931b*: 35, fig. 32a-d; Paulsen, 1931*: 89, fig. 55A-F; Steemann Nielsen, 1934*: 25, fig. 60-62; Schiller, 1937*: 422, fig. 463a-d; Rampi, 1939*: 308, fig. 32, 33, 40 (C. massiliense (Gourret) Jörg. f. armatum (Karsten) Jörg., f. macroceroides (Karsten) Jörg. and f. protuberans (Karsten) Jörg.); Graham \& Bronikovsky, 1944*: 38, fig. 22E-L; Wood, 1954*: 306, fig. 235a-c; 1968*: 36, fig. 78; Kato, 1957*: pl. 6, fig. 18, 20 (C. massiliense and C. massiliense var. protuberans (Karsten) Jörgensen); Curl, 1959*: 306, fig. 119; Margalef, 1961a*: 81, fig. 26h, pl. 6, 7, 10; López, 1966*: fig. 51; Sournia, 1968*: 465, fig. 87, 88 (three infraspecific taxa are distinguished); Subrahmanyan, 1968*: 74, pl. 4, fig. 23, pl. 7, fig. 34, 35; Steidinger \& Williams, 1970**: 46, pl. 11, fig. 30a, b, pl. 12, fig. 30c-e; Hermosilla, 1973*: 64, pl. 33, fig. 3, 4; Hassan, 1976*: 290, fig. 9-11 (var. massiliense and var. protuberans); Taylor, 1976*: 73, pl. 20, fig. 193-196; PesantesSantana, 1978*: 15, pl. 3, fig. 1, 2; Trégouboff, 1978*: 116, pl. 26, fig. 15; Tester \& Steidinger, 1979**: 29, pl. 11, fig. 69; Burns \& Mitchell, 1982***: 62, fig. 11-13 (the specimen illustrated in fig. 11 corresponds rather well to C. contrarium; see Sournia, 1968; Balech, 1988); Dowidar, 1983*: 18, pl. 2, fig. 11, pl. 8, fig. 1; Balech, 1988*: 147, pl. 64, fig. 6; Delgado \& Fortuño, 1991***: 6, pl. 9, fig. a, c, pl. 10, fig. a; Licea et al., 1995***: pl. 4, fig. 3 (f. armatum), pl. 19, fig. 6 (var. massiliense); 2004**: fig. 10; Steidinger \& Tangen, 1997*: 477, pl. 33; Konovalova, 1998*: 154, fig. 33(1, 2) (var. massiliense and var. armatum); Alonso-Rodríguez et al., 2008**: 130; Yongshui, 2009******: 45, fig. 52, pl. 3, fig. 5, pl. 13, fig. 1 .

32. Ceratium contrarium (Gourret) Pavillard, 1905 (Pl. 6, Fig. 9; Pl. 13, Fig. 7) Bas.: Ceratium tripos var. contrarium Gourret, 1883: pl. 3, fig. 51.

Syn.: Ceratium trichoceros (Ehrenb.) Kof. var. contrarium (Gourret) J. Schill., 1937: 431, fig. 471.

Cell body rather delicate, subtrapezoidal, with nearly flat, notably oblique posterior margin. Apical horn very long, straight. Proximal parts of the antapical horns are directed laterally-posteriorly, forming a shallow notch between them; distally they bend continuously and are directed anteriorly, being in general slightly divergent or parallel to each other. Antapical horns are often undulating. Posterior membrane is poorly developed. Widest point adjacent to the antapical horns. L 353$640 \mu \mathrm{m}(443.1 \pm 89.7 \mu \mathrm{m}), \mathrm{Wb} 50-65 \mu \mathrm{m}(56.8 \pm 4.2 \mu \mathrm{m}), \mathrm{Wt} 297-420 \mu \mathrm{m}(354.4 \pm 35.8$ $\mu \mathrm{m}) ; \mathrm{n}=25$. 
Affinities: C. trichoceros. In comparison, C. contrarium has a larger cell body and a shallower notch between the proximal parts of the antapical horns. Furthermore, the epitheca is usually slightly lower.

Records in the State of Veracruz: Zamudio-Resendiz, 1998 (as C. cf. contrarium); Estradas-Romero, 2004. Rare to common in NPSAV, throughout the year.

References: Graham \& Bronikovsky, 1944*: 40, fig. 22E, 24A, B; López, 1966*: fig. 46; Sournia, 1968*: 473, fig. 90; Subrahmanyan, 1968*: 82, fig. 148; Wood, 1968*: 26, fig. 49; Hassan, 1976*: 290, fig. 13; Taylor, 1976*: 69, pl. 21, fig. 213; Trégouboff, 1978*: 116, pl. 26, fig. 18; Burns \& Mitchell, 1982***: 62, non fig. 15 (as indicated on p. 62); Licea et al., 1995*: 33, pl. 17, fig. 12; Konovalova, 1998*: 162, fig. 33(8); Yongshui, 2009*: pl. 2, fig. 11.

33. Ceratium trichoceros (Ehrenb.) Kof., 1908 (Pl. 7, Fig. 1; Pl. 13, Fig. 8)

Bas.: Peridinium trichoceros Ehrenb., 1859: 791; 1873: 3, pl. 1(1).

Cell body very delicate, subtrapezoidal, with nearly flat, notably oblique posterior margin. Apical horn very long, straight. Proximal parts of the antapical horns are directed laterally-posteriorly, forming a shallow notch between them; distally they bend continuously and are directed anteriorly, being in general slightly divergent or parallel to each other. Antapical horns are often undulating. Posterior membrane is poorly developed. Widest point adjacent to the antapical horns. L 182-380 $\mu \mathrm{m}(318.8 \pm 48.0$ $\mu \mathrm{m}), \mathrm{Wb} 30-45 \mu \mathrm{m}(39.3 \pm 3.1 \mu \mathrm{m}), \mathrm{Wt} 230-340 \mu \mathrm{m}(286.7 \pm 29.7 \mu \mathrm{m}) ; \mathrm{n}=23$.

Affinities: C. contrarium. In comparison, C. trichoceros has a smaller cell body and a deeper notch between the proximal parts of the antapical horns. Additionally, the epitheca is usually slightly higher.

Records in the State of Veracruz: Figueroa-Torres, 1990***; Zamudio-Resendiz, 1998; Aquino-Cruz, 2002***; Tejeda-Hernández, 2005**. Very common in NPSAV, probably, throughout the year.

References: Jörgensen, 1911*: 75, fig. 159a, b; 1920*: 95, fig. 85; Steemann Nielsen, 1934*: 27, fig. 68; Schiller, 1937*: 430, fig. 470; Rampi, 1939*: 310, fig. 39; Graham \& Bronikovsky, 1944*: 40, fig. 22B; Kato, 1957*: 19, pl. 6, fig. 19a, b; Margalef, 1961a*: 81, fig. 26i, pl. 6, 8, 10; López, 1966*: fig. 44, 45; Sournia, 1968*: 472, fig. 89; Steidinger et al., 1967**: pl. 6, fig. c; Subrahmanyan, 1968*: 81, fig. 147, pl. 7, fig. 37; Wood, 1968*: 40, fig. 91; Steidinger \& Williams, 1970**: 47, pl. 14, fig. 36a-c; Hassan, 1976*: 290, fig. 12; Taylor, 1976*: 75, pl. 12, fig. 117, pl. 21, fig. 210; Pesantes-Santana, 1978*: 18, pl. 13, fig. 1, 2; Tester \& Steidinger, 1979**: 29, pl. 12, fig. 72; Burns \& Mitchell, 1982***: fig. 16; Dowidar, 1983*: 18, pl. 4, fig. 2; Balech, 
1988*: 150, pl. 66, fig. 4; Licea et al., 1995**: 47, pl. 5, fig. 4; 2004**: fig. 4; Steidinger \& Tangen, 1997*: 478, pl. 29; Konovalova, 1998***: 162, pl. 14(1-4); Avancini et al., 2006***: 301, fig. A, B; Alonso-Rodríguez et al., 2008**: 131; Yongshui, 2009* $* * * * *$ : 48, fig. 56, pl. 3, fig. 7, pl. 13, fig. 2.

\section{DISCUSSION}

The total absence of any species of the subgenus Archaeoceratium Jörgensen (Ceratium cephalotum (Lemmerm.) Jörg., C. praelongum (Lemmerm.) Kof. and C. gravidum Gourret) in the present samples can be explained by their preference for oceanic waters. Furthermore, they are umbriphilic (shade-loving, or shade species), preferring depths below 50-100 m (Steemann Nielsen, 1934, Graham \& Bronikowsky, 1944; Taylor, 1976). Steidinger et al. (2009) report these species from the Gulf of Mexico. The first two species have been reported from offshore waters of the State of Veracruz (Figueroa-Torres, 1990).

Only a small amount of information about the species composition of Ceratium in Veracruz waters exists in a dozen BSc and MSc theses and one article in a periodical of very limited distribution. Three of the theses include very schematic line drawings or photographs of several species (Suchil-Vilchis, 1990; Aquino-Cruz, 2002; Tejeda-Hernández, 2005). Work on a Ceratium furca var. hircus bloom includes photos of this species (Guerra-Martínez \& Lara-Villa, 1996). Thus, a robust critical review of existing records of the species of Ceratium in Veracruz water is impossible. Moreover, there are species never observed in our samples that have been reported by other authors from Veracruz-southern Tamaulipas waters: C. concilians Jörg., C. deflexum (Kof.) Jörg., C. lineatum (Ehrenb.) Cleve, C. longinum G. Karst., C. longipes (Bailey) Gran, C. minutum Jörg. and C. paradoxides Cleve (Avendaño-Sánchez \& Sotomayor-Navarro, 1982; Figueroa-Torres, 1990; Suchil-Vilchis, 1990; Zamudio-Resendiz, 1998; Aquino-Cruz, 2002; Estradas-Romero, 2004). C. concilians can be easily confused with C. gibberum (e.g., see Böhm, 1931a: 379, fig. 36A-F), although Balech (1988) distinguishes them by a number of features. $C$. deflexum is morphologically similar to C. macroceros, and therefore some authors have probably confused them, according to Pavillard (1931) and Sournia (1968); others considered it a subspecies of $C$. macroceros (Jörgensen, 1911) or a form of $C$. massiliense (Peters, 1934). Identifications of $C$. lineatum and C. minutum are likely to be misidentifications, at least in some cases: confusion between them and C. kofoidii, $C$. teres and even with specimens of $C$. pentagonum with a short apical horn 
(all three species are very common in the NPSAV) are quite possible. C. lineatum is widely distributed, and it has an Antarctic-tropical-boreal range (Okolodkov, 1996). C. longinum is mentioned in the present paper as a synonym to C. contortum, in accordance with Graham \& Bronikovsky (1944) and Taylor (1976). Wood (1968) treats it separately and also indicates the similarity between C. longinum and C. karstenii. As for C. longipes, it is a cold-water species and may be confused with C. horridum (Wood, 1968; Steidinger \& Tangen, 1997; Konovalova, 1998), which is rather common in the tropical zone, making a misidentification possible. Its distribution seems to be limited by the temperate (boreal) zone in the Northern Hemisphere; it is characteristically absent in the classic monographs by Sournia (1968), Taylor (1976) and Balech $(1976,1988)$, and in the checklist of dinoflagellates of the Mexican Pacific (Okolodkov \& Gárate-Lizárraga, 2006). C. paradoxides is a rare umbriphilic oceanic species (Balech, 1988) morphologically similar to C. limulus.

New records (Ceratium dens, C. bigelowii, C. limulus, C. tripos f. tripodoides and $C$. declinatum var. angusticornum) for the Mexican part of the Gulf of Mexico were mainly from an oceanographic station situated further from the coastline. In some samples $C$. dens was rather frequent. Although a recent extension of its original geographic range in the Pacific Ocean might occur (Gárate-Lizárraga, 2009), it is hard to say if it is true for the Gulf of Mexico. Because the so-called grey literature (in particular, theses) was considered in the present study, the percentage of new records is relatively low. On the other hand, the data presented here are generally in agreement with those taken from the revised theses.

One of the varieties of Ceratium tripos, var. pulchellum (Schröder) López ex Sournia (= C. pulchellum Schröder), reported by Figueroa-Torres (1990) and Zamudio-Resendiz (1998) was not observed in the samples from the NPSAV. This species was one of the most abundant, and it was difficult to distinguish between var. tripos and var. breve. The specimens of $C$. tripos var. tripodoides, easily distinguishable from others, were usually rare and occasionally were more frequent than the other two.

On the whole, the species composition of Ceratium in the NPSAV is very similar to that in any well-studied tropical or subtropical region (Sournia, 1968; Subrahmanyan, 1968; Wood, 1968; Steidinger \& Williams, 1970; Taylor, 1976) and in particular to that previously reported (Figueroa-Torres, 1990) in Veracruz waters. It consists of about $67 \%$ of the number of Ceratium species reported by Licea et al. (2004) for the southern Gulf of Mexico (based on 11 oceanographic cruises and 608 sampling sites between 1979 and 2002) and approximately 47\% of the total number of Ceratium species known for the entire Gulf of Mexico (Steidinger et al., 2009). 


\section{ACKNOWLEDGMENTS}

The generosity of Guadalupe Campos-Bautista, responsible for the red-tide project at the Acuario de Veracruz, A.C., in providing samples is very much appreciated. The Acuario de Veracruz is thanked for logistic support. I am thankful to Marcia M. Gowing from the University of California at Santa Cruz, California, who kindly improved the writing style, and to Natalia Okolodkova and Boris Okolodkov who prepared illustrations for publication. Fany del Carmen Merino-Virgilio of CINVESTAV (Merida, Yucatan, Mexico) is thanked for technical support. I also thank two anonymous referees. The financial support of Dirección General de Investigaciones de la Universidad Veracruzana, Mexico (the project "Algas de la zona arrecifal Veracruzana, Golfo de México, con énfasis en las algas rojas, diatomeas y dinoflagelados"), in 2007-2009 is also appreciated.

\section{LITERATURE CITED}

Alonso-Rodríguez, R., D. Hernández-Becerril \& I. Gárate-Lizárraga. 2008. Catálogo de microalgas de las lagunas costeras de Sinaloa. In: Páez-Osuna, F. (ed.). Lagunas Costeras de Sinaloa. Universidad Nacional Autónoma de México, Instituto de Ciencias del Mar y Limnología (Estación Mazatlán), Colegio de Sinaloa, Comité Estatal de Sanidad Acuícola de Sinaloa, Secretaría de Medio Ambiente y Recursos Naturales, y Consejo Nacional de Ciencia y Tecnología. Culiacán. 198 pp.

Aquino-Cruz, A. 2002. Presencia de dinoflagelados (Pyrrhophyta), con énfasis en productoras potenciales de marea roja, en Playa Paraíso, Ver. Tesis profesional. Facultad de Biología, Universidad Veracruzana. Xalapa, Veracruz. 72 pp.

Avancini, M., A. M. Cicero, I. Di Girolamo, M. Innamorati, E. Magaletti \& T. Sertorio Zunini. 2006. Guida al riconoscimento del plancton dei mari italiani. Vol. I. Fitoplancton. Ministero dell'Ambiente della Tutela del Territorio e del Mare - DPN, Instituto Centrale per la Ricerca Scientifica e Tecnologica Applicata al Mare. Roma. 505 pp.

Avendaño-Sánchez, H. \& O. Sotomayor-Navarro. 1982. Estructura y distribución de las comunidades fitoplanctónicas de la zona sureste del Golfo de México, verano de 1980. Investigaciones Oceanográficas. Secretaría de Marina, Dirección General de Oceanografía, Biología Marina, México, D.F. 1(3): 79-96.

Balech, E. 1967. Microplankton of the Gulf of Mexico and Caribbean Sea. Texas A\&M Research Foundation 67-I0-T: 1-144.

Balech, E. 1976. Clave ilustrada de dinoflagelados antárticos. Publ. Instituto Antártico Argentino 11. Buenos Aires. 99 pp.

Balech, E. 1988. Los dinoflagelados del Atlántico Sudoccidental. Ministerio de Agricultura Pesca y Alimentación, Publ. Espec. Inst. Esp. Oceanogr. Núm. 1. Madrid. 310 pp. 
Bérard-Therriault, L., M. Poulin \& L. Bossé. 1999. Guide d'identification du phytoplancton marin de l'estuaire et du golfe du Saint-Laurent: incluant également certains protozoaires. Les Presses Scientifiques du Conseil National de Recherches du Canada. Ottawa. 387 pp.

Böhm, A. 1931a. Die Adriatischen Ceratien. Bot. Arch. 31: 349-385.

Böhm, A. 1931b. Distribution and variability of Ceratium in the northern and western Pacific. Bernice P. Bishop Museum (Honolulu, Hawaii) 87: 1-47.

Burns, D. A. \& J. S. Mitchell. 1980. Some dinoflagellates of the genus Ceratium from around New Zealand. N. Z. J. Mar. Freshw. Res. 14(2): 149-153.

Burns, D. A. \& J. S. Mitchell. 1982. Further examples of the dinoflagellate genus Ceratium from New Zealand coastal waters. N. Z. J. Mar. Freshw. Res. 16: 57-67.

Curl, H., Jr. 1959. The phytoplankton of Apalachee Bay and the Northeastern Gulf of Mexico. Publications of the Institute of Marine Science, The University of Texas. Port Aransas, Texas 6: 277-320.

Dangeard, P. 1927. Phytoplancton de la croisière du Sylvana (Fevrier-Juin 1913). Ann. Inst. Océanogr. Monaco 4(8): 285-407.

Delgado, M. \& J.-M. Fortuño. 1991. Atlas de fitoplancton del Mar Mediterráneo. Sci. Mar. 55(Suppl. 1): 1-133.

Dodge, J. D. 1982. Marine dinoflagellates of the British Isles. HM Stat. Office. London. 303 pp.

Dodge, J. D. 1985. Atlas of dinoflagellates: a scanning electron microscope survey. Farrand Press. London. 119 pp.

Dodge, J. D. 1993. Biogeography of the planktonic dinoflagellate Ceratium in the Western Pacific. Korean J. Phycol. 8(2): 109-119.

Dodge, J. D. \& H. G. Marshall. 1994. Biogeographic analysis of the armored planktonic dinoflagellate Ceratium in the North Atlantic and adjacent seas. J. Phycol. 30: 905922.

Dowidar, N. M. 1983. The genus Ceratium from the Red Sea. J. Fac. Mar. Sci. (Egypt) 3: 5-37.

Drebes, G. 1974. Marines Phytoplankton. Eine Auswahl der Helgoländer Planktonalgen (Diatomeen, Peridineen). Georg Thieme Verlag. Stuttgart. 186 pp.

Echeverría-Valencia, M. E. 1983. Variación estacional de los dinoflagelados (Protozoa, Phytomastigophorea) de la laguna de Mandinga, Veracruz. Tesis profesional. Facultad de Ciencias, Universidad Nacional Autónoma de México. México, D.F. 62 pp., 8 lám.

Estradas-Romero, A. 2004. Abundancia y distribución del fitoplancton en dos transectos, uno frente al Río Coatzacoalcos y otro frente al sistema Grijalva-Usumasinta (Marzo 2000). Tesis de maestría. Posgrado en Ciencias del Mar y Limnología, Universidad Nacional Autónoma de México. México, D.F. 70 pp.

Figueroa-Torres, M. G. 1990. Sistemática y distribución del género Ceratium Schrank 1793, en el sur del Golfo de México (feb.-dic. 1987). Tesis de maestría. Facultad de Ciencias, Universidad Nacional Autónoma de México. México, D.F. 51 pp., 6 tablas, 7 lám.

Frost, N. \& A. M. Wilson. 1938. The genus Ceratium and its use as an indicator of hydrographic conditions in the Newfoundland waters. Newfoundland Res. Bull. 5: 1-15. 
Gaarder, K. R. 1954. Dinoflagellatae from the "Michael Sars" North Atlantic Deep-Sea Expedition 1910. Rep. Sci. Res. “M. Sars” North Atlant. Deep-Sea Exped. 1910 2(3): 1-62.

Gárate-Lizárraga, I. 2009. First record of Ceratium dens (Dinophyceae) in the Gulf of California. CICIMAR Oceánides 24(2): 167-173.

García-Reséndiz, J. A. 2003. Estructura del fitoplancton y su relación con las condiciones oceanográficas en el sureste del Golfo de México (abril 2000). Tesis de licenciatura. Facultad de Biología, Universidad Veracruzana. Xalapa, Veracruz. 46 pp.

Gómez, F., D. Moreira, \& P. López-García. 2010. Neoceratium gen. nov., a new genus for all marine species currently assigned to Ceratium (Dinophyceae). Protist 161: 35-54.

Graham, H. W. 1941. An oceanographic consideration of the dinoflagellate genus Ceratium. Ecol. Monogr. 11(1): 101-115.

Graham, H. W. \& N. Bronikovsky. 1944. The genus Ceratium in the Pacific and North Atlantic oceans. Scientific results of cruise VII of the Carnegie during 1928-1929 under command of Captain J.P. Ault. Carnegie Institution of Washington Publication 565, Washington, D.C. vii+209 pp.

Guerra-Martínez, S. L. \& M. A. Lara-Villa. 1996. "Florecimiento" de Ceratium furca (Peridiniales: Ceratiaceae) en un ambiente salobre: Laguna de Sontecomapan, México. Rev. Biol. Trop. 44(1): 23-30.

Hassan, D. 1976. The genus Ceratium Schrank from coastal waters of Karachi. Part II. The subgenus Euceratium. Bot. Mar. 19: 287-293.

Hassan, D. \& S. M. Saifullah. 1974. The genus Ceratium Schrank from coastal waters of Karachi. Part I. The sub-genera Amphiceratium and Biceratium. Bot. Mar. 17: 82-87.

Hermosilla, J. G. 1973. Contribución al conocimiento sistemático de los dinoflagelados de la Bahía de Concepción, Chile. Gayana, Zool. 24: 1-149.

Hernández-Becerril, D. U. 1988. Especies de fitoplancton tropical del Pacífico mexicano. II. Dinoflagelados y cianobacterias. Rev. Lat. Amer. Microbiol. 30: 187-196.

Hernández-Mendiola, M. 1988. Fluctuaciones espacio-temporales en la estructura de la comunidad fitoplanctónica, en la zona estuarina del río La Antigua, Veracruz, México. Tesis de licenciatura. Facultad de Biología, Universidad Veracruzana. Xalapa, Veracruz. 88 pp.

Hoppenrath, M., M. Elbrächter \& G. Drebes. 2009. Marine phytoplankton. Selected microphytoplankton species from the North Sea around Helgoland and Sylt. E. Schweizerbart'sche Verlagsbuchhandlung (Nägele u. Obermiller). Stuttgart. 264 pp. Jörgensen, E. 1911. Die Ceratien. Eine kurze Monographie der Gattung Ceratium Schrank. Intern. Rev. d. ges. Hydrobiol. u. Hydrogr. 4, Suppl. Heft, Pt. 1: 1-124, 10 pl.

Jörgensen, E. 1920. Mediterranean Ceratia. Report on the Danish Oceanographical Expeditions 1908-10 to the Mediterranean and adjacent seas. Vol. 2. Biology, J. 1: 1-110.

Karsten, G. 1907. Das Indische Phytoplankton nach dem Material der Deutschen TiefseeExpedition 1898-1899. Wiss. Ergebn. der Deutschen Tiefsee-Expedition auf dem Dampfer "Valdivia” 1898-1899 2(2, 3): 221-548.

Kato, N. 1957. On the species of "Ceratium" (Dinoflagellata) from Manazuru and its vicinity. I. Sci. Rep. Yokohama Natl. Univ., Sect. 2, 6: 11-20, 5 pl. 
Kiselev, I. A. 1950. Thecate flagellates (Dinoflagellata) of the seas and freshwater reservoirs of the USSR. Izdatelstvo AN SSSR (USSR Academy of Sciences Publishing House). Moscow, Leningrad. 280 pp.

Kofoid, C. A. 1907a. New species of dinoflagellates. Bull. Mus. Comp. Zool. Harv. Coll. 50(6): 163-207, pl. 1-18.

Kofoid, C. A. 1907b. Dinoflagellata of the San Diego region. III. Description of new species. Univ. Calif. Publ. Zool. 3: 299-340.

Konovalova, G. V. 1998. Dinoflagellatae (Dinophyta) of the Far Eastern seas of Russia and adjacent waters of the Pacific Ocean. Dalnauka. Vladivostok. 300 pp.

Konovalova, G. V., T. Y. Orlova, \& L. A. Pautova. 1989. Atlas of phytoplankton of Japan Sea. Nauka. Leningrad. 160 pp.

Lebour, M. V. 1925. The dinoflagellates of northern seas. Mar. Biol. Ass. UK, Plymouth. $250 \mathrm{pp}$.

Legaría-Moreno, L. 2003. Dinámica del fitoplancton y su relación con variables físicoquímicos en la laguna costera La Mancha, Ver., Méx. Tesis de licenciatura. Facultad de Biología, Universidad Veracruzana. Xalapa, Veracruz. 138 pp.

Licea, S., J. L. Moreno, H. Santoyo \& G. Figueroa. 1995. Dinoflageladas del Golfo de California. Universidad Autónoma de Baja California Sur, Secretaría de Educación Pública Fondo para la Modernización de la Educación Superior, Programa Interdisciplinario e Interinstitucional Mar de Cortés. La Paz, Baja California Sur. xii+165 pp.

Licea, S., M. E. Zamudio, R. Luna \& J. Soto. 2004. Free-living dinoflagellates in the southern Gulf of Mexico: report of data (1979-2002). Phycol. Res. 52: 419-428.

López, J. 1966. Variación y regulación de la forma en el género Ceratium. Inv. Pesq. 30: 325-427.

López-Baluja, L. 1980. Distribución fitogeográfica de Ceratium furca (Ehrenberg) Claparade y Lachmann var. hircus (Schroder) Margalef (Dinoflagellatae Peridinidae). Informe Científico-Técnico 121/Octubre de 1980, Editora de la Academia de Ciencias de Cuba, La Habana. 9 pp.

Margalef, R. 1961a. Hidrografía y fitoplancton de un área marina de la costa meridional de Puerto Rico. Invest. Pesq. 18: 33-96.

Margalef, R. 1961b. Fitoplancton atlántico de las costas de Mauritania y Senegal. Invest. Pesq. 20: 131-143.

Meave del Castillo, M. E., M. E. Zamudio-Resendiz, Y. B. Okolodkov, I. Salgado \& S. Guerra-Martínez. 2003. Ceratium balechii sp. nov. (Dinophyceae: Gonyalacales) del Pacífico Mexicano. Hidrobiológica 13(1): 75-90.

Ochoa-Figueroa, E. 1978. Estudio de la distribución de algunos dinoflagelados y su relación con factores físico-químicos en la laguna de Tamiahua, Veracruz, México. Tesis de licenciatura. Facultad de Biología, Universidad Veracruzana. Xalapa, Veracruz. 31 pp.

Okolodkov, Y. B. 1996. Net phytoplankton from the Barents Sea and Svalbard waters collected on the cruise of the R/V "Geolog Fersman" in July-September 1992, with emphasis on the Ceratium species as biological indicators of the Atlantic waters. Bot. J. Russ. Acad. Sci. 81(10): 1-9.

Okolodkov, Y. B. \& I. Gárate-Lizárraga. 2006. An annotated checklist of dinoflagellates (Dinophyceae) from the Mexican Pacific. Acta Bot. Mex. 72: 1-154. 
Ostenfeld, C. H. 1903. Phytoplankton from the sea around the Færöes. Botany of the Færöes 2: 558-612.

Ostenfeld, C. H. \& J. Schmidt. 1901. Plankton fra det Rode Hav og Abenbugten (Plankton from the Red Sea and the Gulf of Aden). Vidensk. Medd. Dansk. Naturh. Foren. 25: 161-182.

Paulsen, O. 1907. The Peridiniales of the Danish waters. Medd. Komm. for Havunders. Ser. Plankton 1(5): 1-26.

Paulsen, O. 1908. Peridiniales. Nordisches Plankton. Botanischer Teil. Verlag von Lipsius \& Tischer. Kiel, Leipzig. 124 pp.

Paulsen, O. 1931. Études sur le microplancton de la mer d'Alboran. Trab. Inst. Esp. Oceanogr. 4: 1-108.

Pavillard, J. 1916. Recherches sur les péridiniens de golfe du Lion. Trav. Inst., Bot. Univ. Montpellier, Sér. Mixte, Mem. 4: 9-70, pl. 1-3.

Pavillard, J. 1931. Phytoplankton (Diatomées, Péridiniens) provenant des campagnes scientifiques du Prince Albert de Monaco. Rés. Camp. Scient. 82: 1-200, 3 pl.

Pesantes-Santana, F. 1978. Dinoflagelados del fitoplancton del Golfo de Guayaquil. Publ. Instituto Oceanográfico, Armada del Ecuador, Guayaquil, Ecuador 2(2): 1-98.

Peters, N. 1934. Die Bevölkerung des sudatlantischen Ozeans mit Ceratien. Wiss. Ergebn. Dt. Atlant. Exped. Meteor 12(1): 1-69.

Rampi, L. 1939. Ricerche sul fitoplancton del mare Ligure. 1. - I Ceratium delle acque di Sanremo. N. Giorn. Bot. Ital., N. S. 46(2): 299-312.

Rampi, L. 1942. Ricerche sul fitoplancton del mare Ligure. 4. - I Ceratium delle acque di Sanremo. Part II. N. Giorn. Bot. Ital., N. S. 49(2): 221-236.

Rampi, L. 1951. Osservazioni su qualche Peridinea del mare Ligure. Centro Talassografico Tirreno, Pubbl. 10. Genova. 8 pp.

Schiller, J. 1937. Dinoflagellatae (Peridineae). Teil 2. Akademische Verlagsgesellschaft M.B.H., Leipzig. 590 pp.

Silva, E. S. 1952a. Estúdios de plâncton na Lagoa de Óbidos. I. Diatomáceas e dinoflagelados. Ver. Fac. Ciênc. Lisboa, sér. 2, 2(1): 5-44.

Silva, E. S. 1952b. Diatomáceas e dinoflagelados das águas litorais da Guiné Portuguesa. Bol. Cultur. Guiné Portug. 27: 585-606.

Silva, E. S. 1956. Contribution à l'étude du microplancton de Dakar et des régions maritimes voisines. Bull. l'I.F.A.N. 18, sér. A, 2: 22-80.

Sournia, A. 1968. Le genre Ceratium (péridinien planctonique) dans le canal de Mozambique. Contribution à une révision mondiale. Vie et Milieu 18(2-3A): 375-499.

Sournia, A. 1973. Catalogue des espèces et taxons infraspécifiques de Dinoflagellés marins actuels publiés depuis la révision de J. Schiller. I. Dinoflagellés libres. Beih. Nova Hedw. 48. i-xii + 1-92.

Sournia, A. 1986. Atlas du phytoplankton marin. Vol. 1: Introduccion, Cyanophycées, Dictyochophycées, Dinophycées et Raphidophycées. Éditiones du CNRS. Paris. 219 pp.

Steemann Nielsen, E. 1934. Untersuchungen über die Verbreitung, Biologie und Variation der Ceratien im südlichen Stillen Ozean. Dana Rep. 1(4): 1-68. 
Steidinger, K. A., J. T. Davis \& J. Williams. 1967. A key to the marine dinoflagellate genera of the west coast of Florida. State of Florida Board of Conservation Technical Series 52. vii+45 pp.

Steidinger, K. A. \& J. Williams. 1970. Dinoflagellates. Memoirs of the Hourglass Cruises 2. Marine Research Laboratory, Florida Department of Natural Resources, St. Petersburg, Florida. 251 pp., pl. 1-45.

Steidinger, K. A. \& K. Tangen. 1997. Dinoflagellates. In: Tomas, C. R. (ed.). Identifying marine phytoplankton. Academic Press, Inc. San Diego, California, USA. pp. 387589.

Steidinger, K. A., A. M. Faust \& D. U. Hernández-Becerril. 2009. Dinoflagellates (Dinoflagellata) of the Gulf of Mexico. In: Tunnel, J. W. Jr., D. L. Felder \& S. A. Earl (eds.). Gulf of Mexico origin, waters, and biota. Vol. 1. Biodiversity. Harte Research Institute for Gulf of Mexico Studies Series, Texas A\&M University Press. Corpus Christi, USA. pp. 131-154.

Subrahmanyan, R. 1968. The Dinophyceae of the Indian seas. Part I. Genus Ceratium. Mar. Biol. Assoc. India, Mar. Fisher. P. O. Mandapam Camp. iv+129 pp.

Suchil-Vilchis, M. A. 1990. Determinación de la variación estacional del fitoplancton, y su relación con los parámetros físicos y químicos de las lagunas de: Sontecomapan y del Ostión/ Ver. para el año de 1985. Tesis profesional. Escuela Nacional de Estudios Profesionales-Zaragoza, Universidad Nacional Autónoma de México. México, D.F. 117 pp.

Taylor, F. J. R. 1976. Dinoflagellates from the International Indian Ocean Expedition. A report on material collected by the R. V. "Anton Bruun" 1963-1964 // Bibliotheca Botanica. Hf. 132. 234 pp., 46 pl.

Taylor, F. J. R. 1978. Dinoflagellates (Chapter 6. Identification problems. Some specific preparations). In: Sournia, A. (ed.). Phytoplankton manual. Monographs on oceanographic methodology 6. UNESCO. Paris. pp. 143-147.

Tejeda-Hernández, I. E. 2005. Identificación y cuantificación de microalgas productoras de marea roja, en las costas de Veracruz, Boca del Río y Antón Lizardo durante la primavera y verano del 2003. Tesis profesional. Instituto Tecnológico del Mar. Boca del Río, Ver. 84 pp.

Temponeras, M., J. Kristiansen, \& M. Moustaka-Gouni. 2000. A new Ceratium species (Dinophyceae) from Lake Doïrani, Macedonia, Greece. Hydrobiologia 424: 101-108.

Tester, L. A. \& K. A. Steidinger. 1979. Phytoplankton, 1971-1973. Florida Marine Research Publications 34: 16-61.

Trégouboff, G. 1978. Dinoflagellata (Peridinineae). In: Trégouboff, G. \& M. Rose. Manuel de planctologie méditerranéenne. Éditions du Centre National de la Recherche Scientifique, Paris. T. I. Texte. 587 pp. T. II. Illustrations. 207 pp.

Wailes, G. H. 1928. Dinoflagellates from British Columbia with descriptions of new species. Study from the stations of the Biological Board of Canada. Vancouver Museum Notes 3: 1-8, $12 \mathrm{pl}$.

Wiktor, J. \& Y. B. Okolodkov. 1995. Phytoplankton. In: Klekowski; R. Z. \& J. M. Weslawski (eds.). Atlas of the marine flora of Southern Spitsbergen. Institute of Oceanology, Polish Academy of Sciences. Gdańsk. pp. 1-295. 
Wood, E. J. F. 1954. Dinoflagellates in the Australian region. Austr. J. Mar. Freshw. Res. 5(2): 171-351.

Wood, E. J. F. 1963. Check-list of dinoflagellates recorded from the Indian Ocean. Rep. Div. Fish. Oceanogr. C.S.I.R.O. Aust. 28: 1-55.

Wood, E. J. F. 1968. Dinoflagellates of the Caribbean Sea and adjacent areas. University of Miami Press. Coral Gables, Florida. 142 pp.

Yongshui, L. 2009. Flora algarum marinarum sinicarum. T. 6. Pyrrophyta. No. 1. Dinophyceae Ceratiaceae. Science Press. Beijing. 93 pp., 18 pl.

Zamudio-Reséndiz, M. E. 1998. Hidrología y fitoplancton en una región costera al oeste del Golfo de México. Tesis de maestría. Instituto de Ciencias del Mar y Limnología, Colegio de Ciencias y Humanidades, Universidad Nacional Autónoma de México. México, D.F. 66 pp. 
Okolodkov: Ceratium (Dinophyceae) of the National Park Sistema Arrecifal Veracruzano
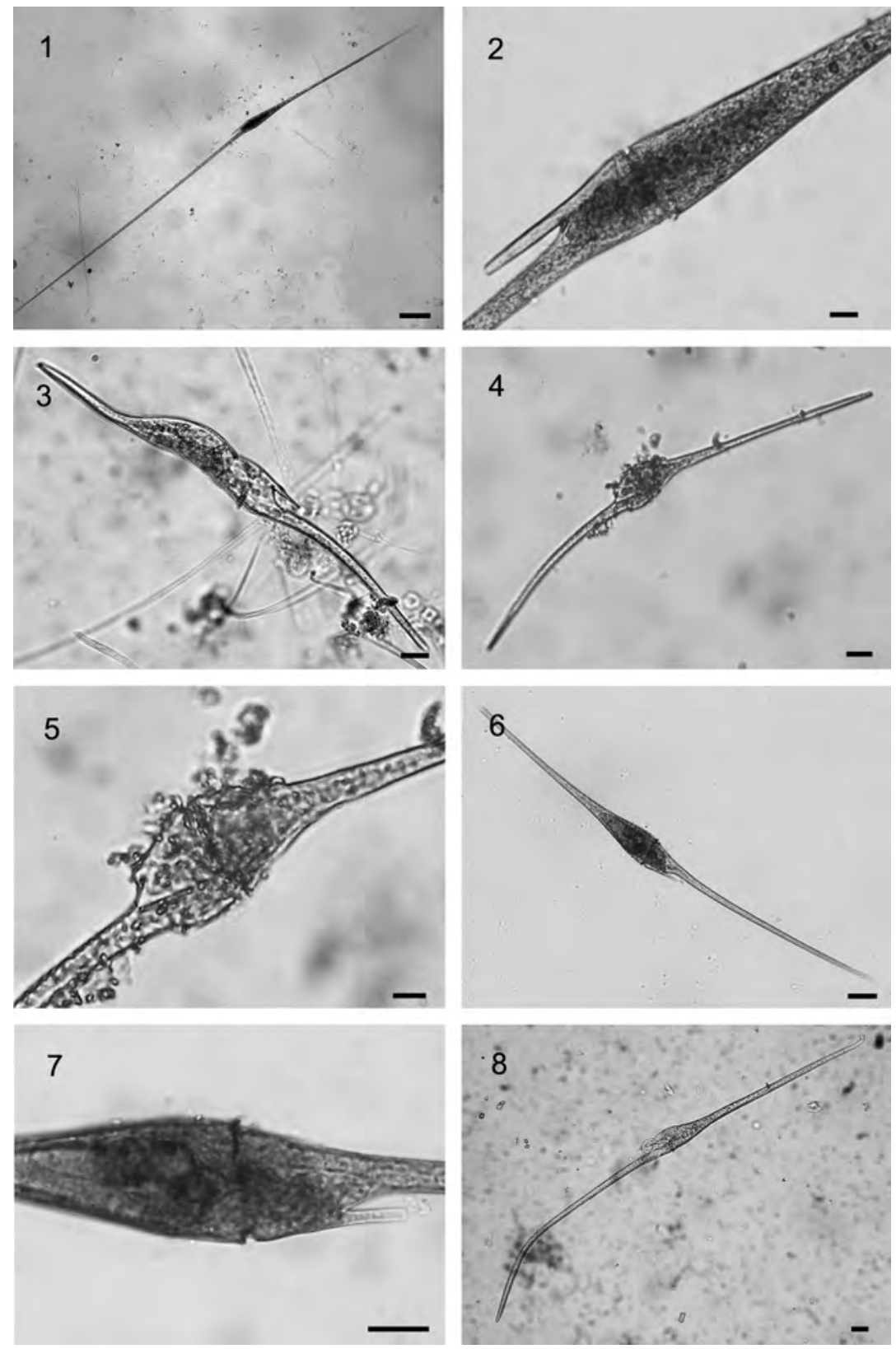

Plate 1. Fig. 1 and 2. Ceratium extensum in ventral view (VV). Fig. 3. C. geniculatum in dorsal view (DV). Fig. 4 and 5. C. bigelowii (VV). Fig. 6 and 7. C. fusus (VV). Fig. 8. C. inflatum (VV). Scale bars: $100 \mu \mathrm{m}$ in Fig. 1; $10 \mu \mathrm{m}$ in Fig. 2, 5 and 7; $20 \mu \mathrm{m}$ in Fig. 3, 4, 6 and 8. 

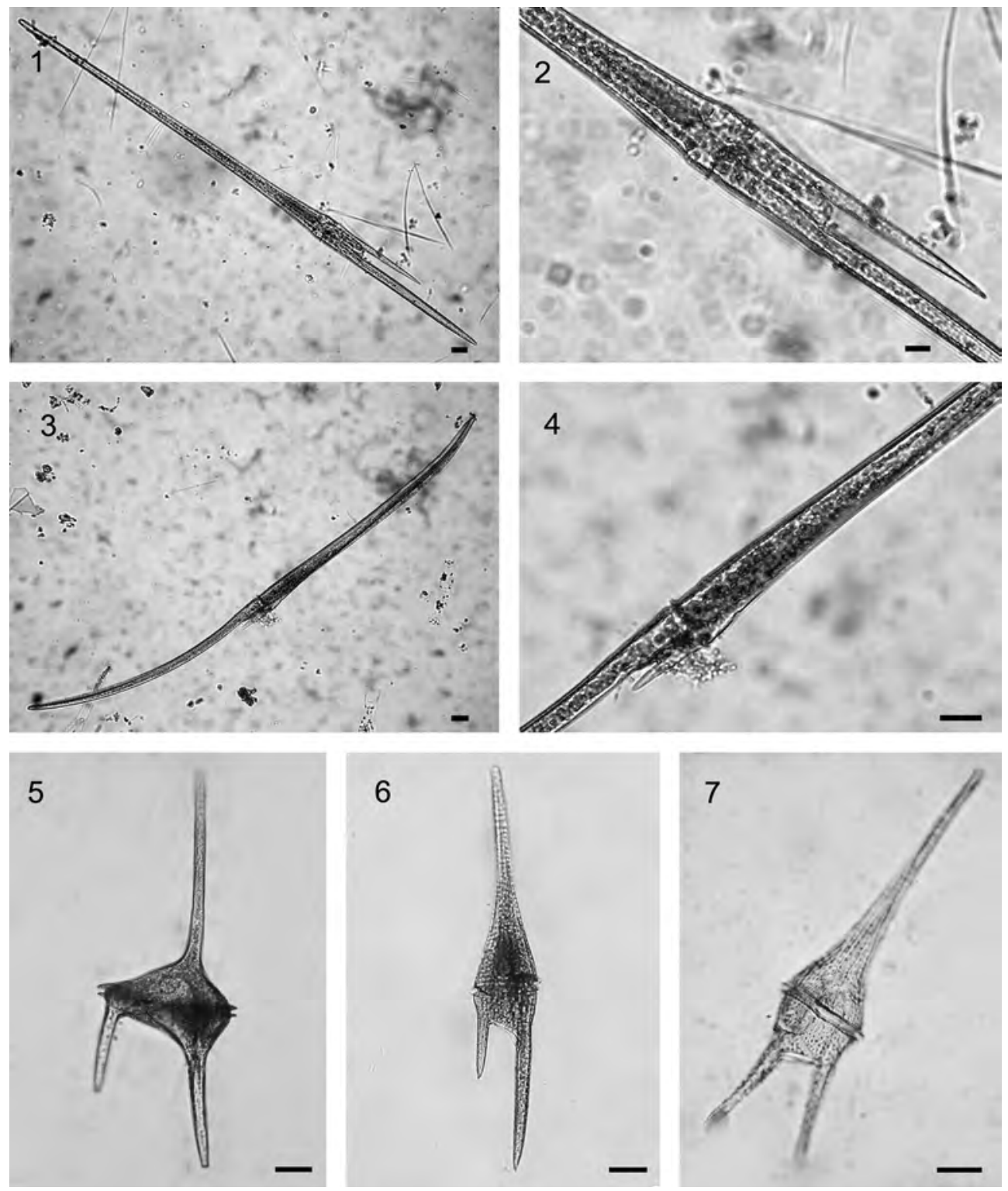

Plate 2. Fig. 1 and 2. Ceratium belone (DV). Fig. 3 and 4. C. longirostrum (DV). Fig. 5. C. candelabrum (VV). Fig. 6. C. furca var. furca (VV). Fig. 7. C. furca var. hircus (DV). Scale bars: $20 \mu \mathrm{m}$ in Fig. 1 and 3-7; $10 \mu \mathrm{m}$ in Fig. 2. 
Okolodkov: Ceratium (Dinophyceae) of the National Park Sistema Arrecifal Veracruzano
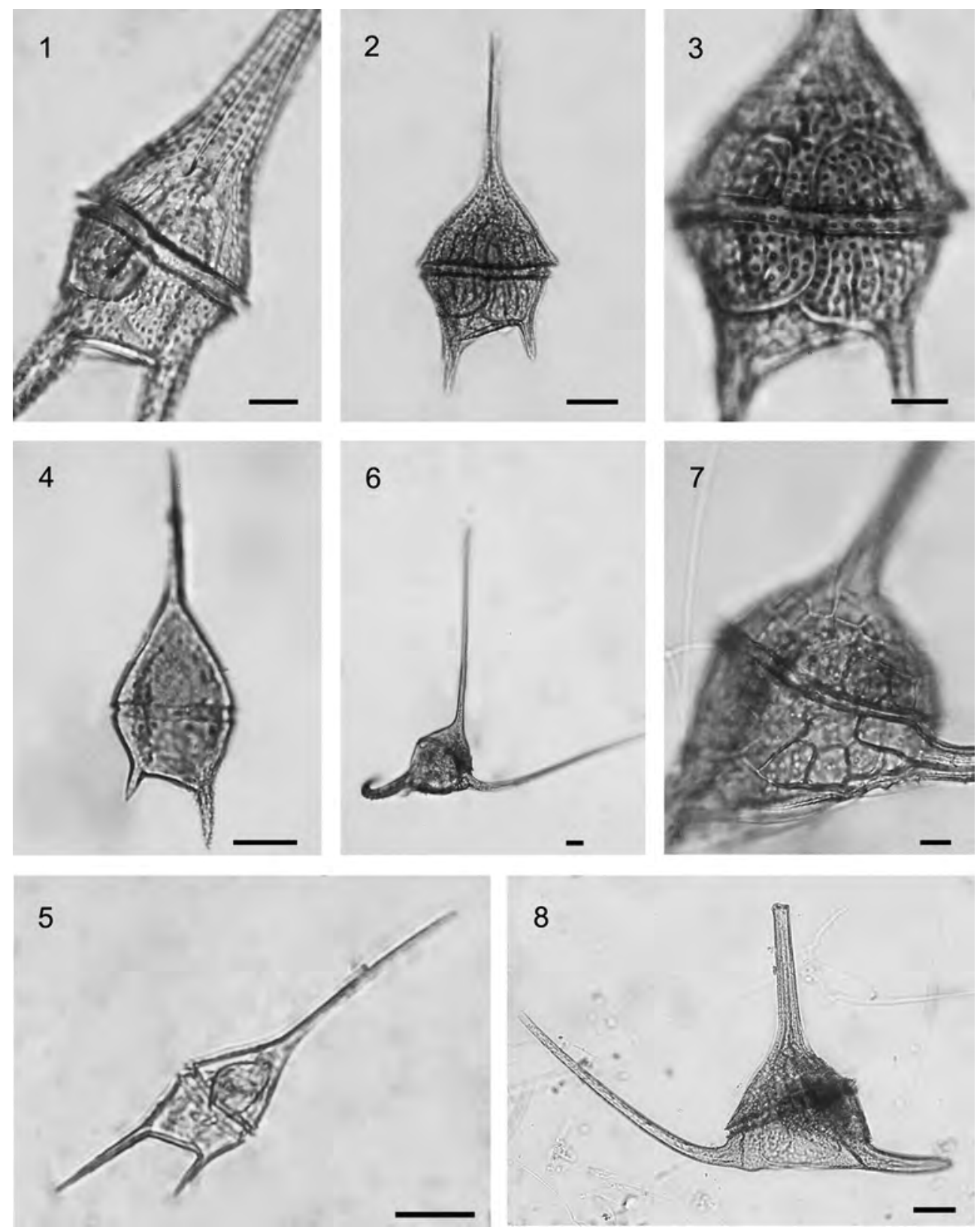

Plate 3. Fig. 1. Ceratium furca var. hircus (DV). Fig. 2 and 3. C. pentagonum var. tenerum (DV). Fig. 4. C. teres (VV). Fig. 5. C. kofoidii (DV). Fig. 6 and 7. C. hexacanthum (DV). Fig. 8. C. dens (VV). Scale bars: $10 \mu \mathrm{m}$ in Fig. 1, 3 and 7; $20 \mu \mathrm{m}$ in Fig. 2, 4-6 and 8. 

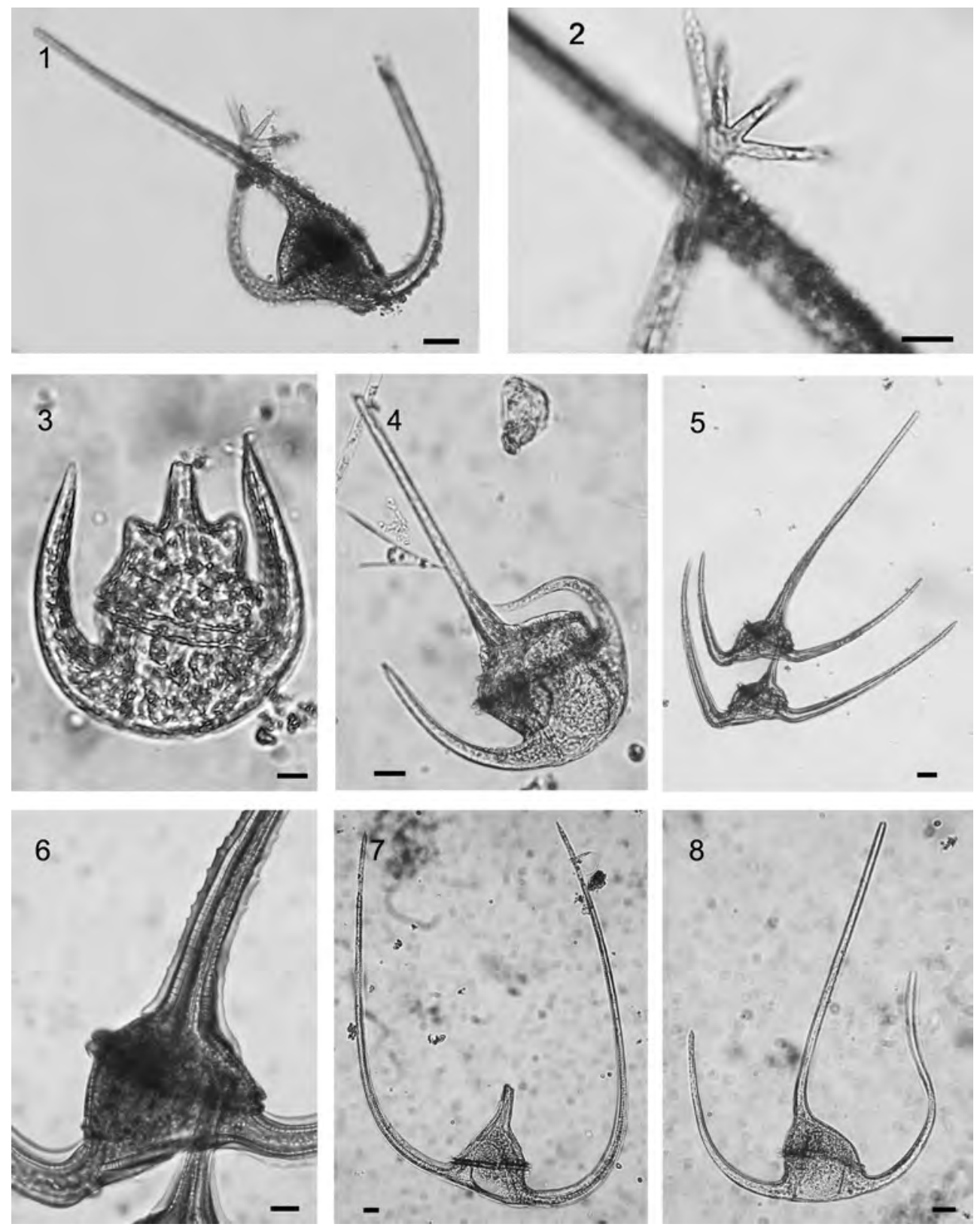

Plate 4. Fig. 1 and 2. Ceratium ranipes (VV). Fig. 3. C. limulus (DV). Fig. 4. C. gibberum var. dispar (DV). Fig. 5 and 6. C. vultur f. vultur, two cells (DV). Fig. 7. C. lunula (VV). Fig. 8. C. contortum var. contortum (DV). Scale bars: $20 \mu \mathrm{m}$ in Fig. 1, 4, 5, 7 and 8; $10 \mu \mathrm{m}$ in Fig. 2, 3, 6. 

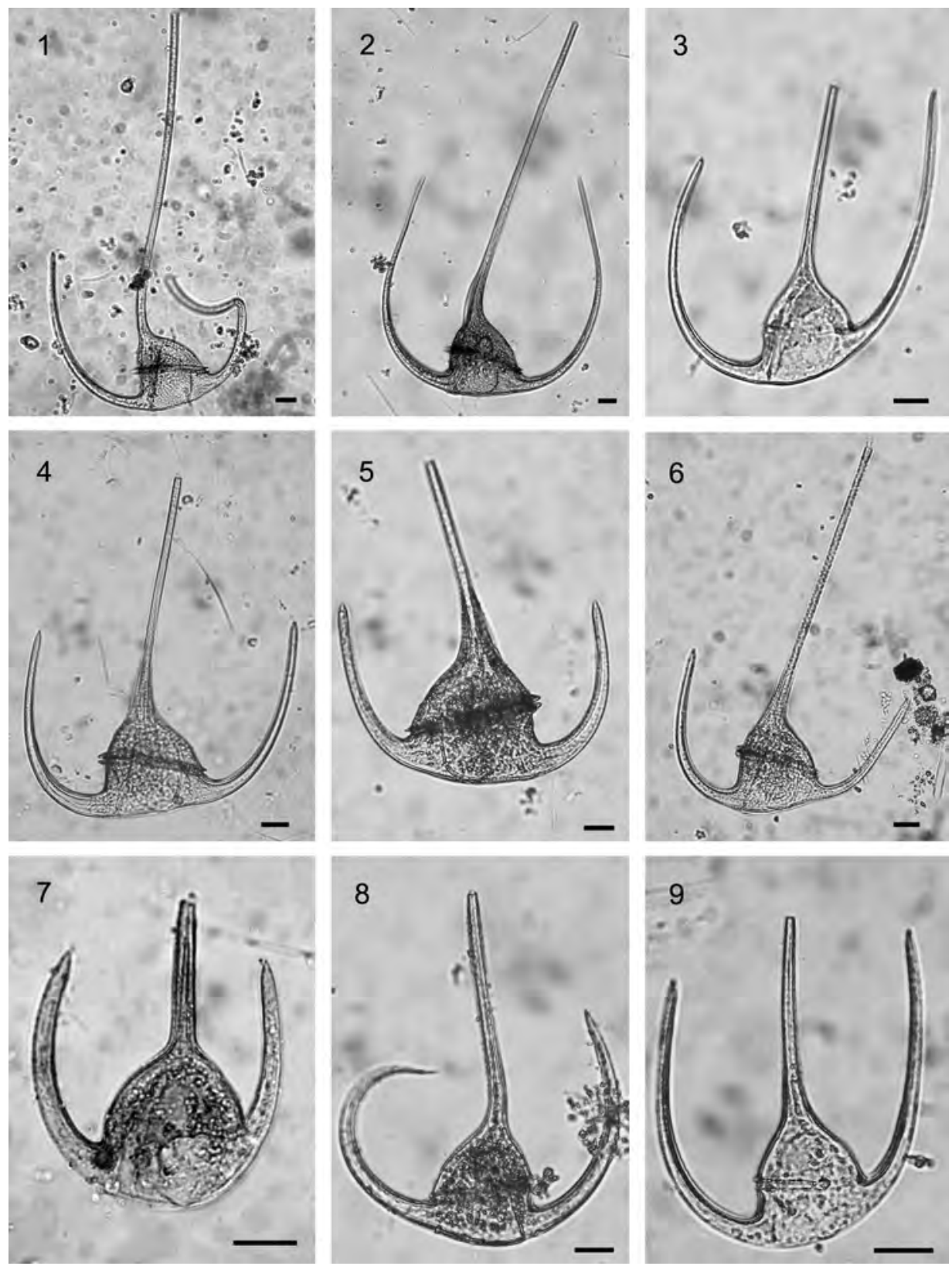

Plate 5. Fig. 1. Ceratium contortum var. saltans (DV). Fig. 2. C. karstenii (DV). Fig. 3. C. euarcuatum (DV). Fig. 4. C. tripos var. tripos (DV). Fig. 5. C. tripos var. breve (VV). Fig. 6. C. tripos f. tripodoides (DV). Fig. 7. C. azoricum (DV). Fig. 8. C. arietinum var. gracilentum (VV). Fig. 9. C. symetricum (DV). Scale bars: $20 \mu \mathrm{m}$. 

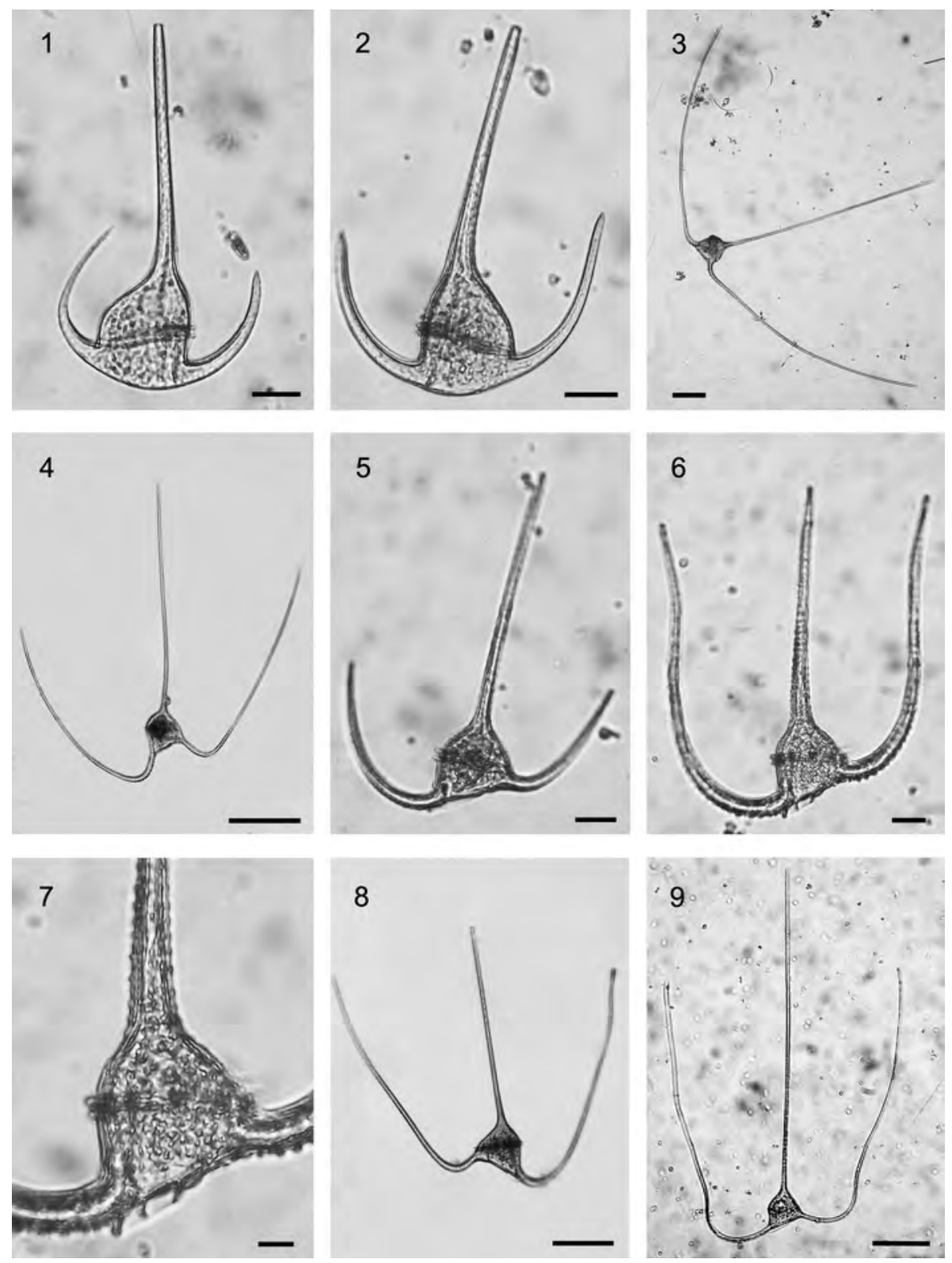

Plate 6. Fig. 1. Ceratium declinatum var. angusticornum (VV). Fig. 2. C. declinatum f. normale (DV). Fig. 3. C. carriense (DV). Fig. 4. C. macroceros var. gallicum (DV). Fig. 5. C. horridum var. buceros (DV). Fig. 6 and 7. C. horridum var. molle (DV). Fig. 8. C. massiliense var. armatum (VV). Fig. 9. C. contrarium (DV). Scale bars: $20 \mu \mathrm{m}$ in Fig. 1, 2, 5 and 6; 100 $\mu \mathrm{m}$ in Fig. 3, 4, 8 and 9; $10 \mu \mathrm{m}$ in Fig. 7. 
Okolodkov: Ceratium (Dinophyceae) of the National Park Sistema Arrecifal Veracruzano
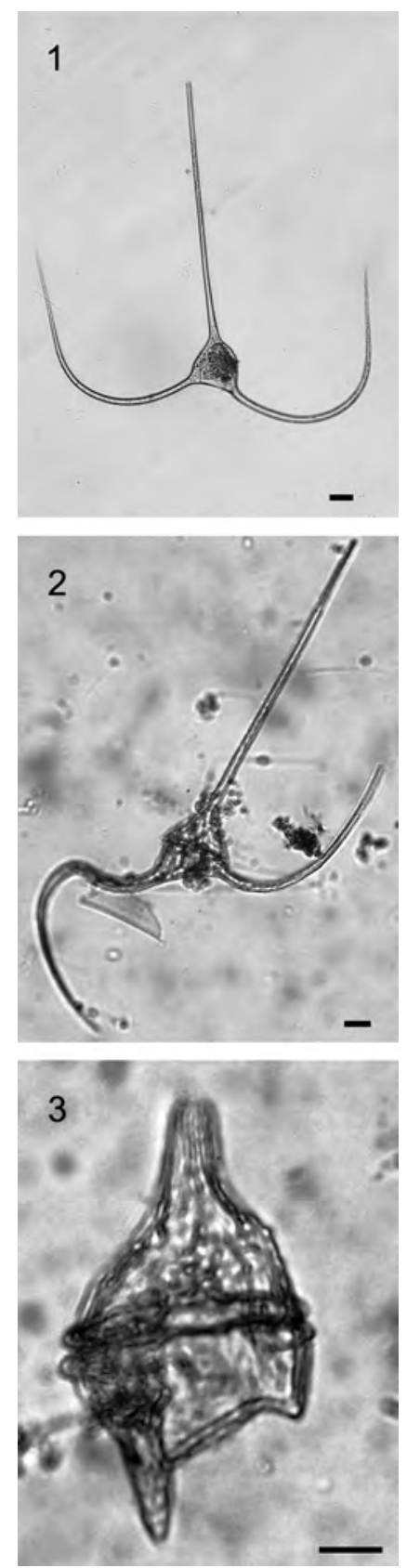

Plate 7. Fig. 1. Ceratium trichoceros (VV). Fig. 2. C. massiliense var. armatum, a teratologic cell (DV). Fig. 3. A microgamete, presumably belonging to C. tripos (DV). Scale bars: $20 \mu \mathrm{m}$ in Fig. 1 and 2; $10 \mu \mathrm{m}$ in Fig. 3. 

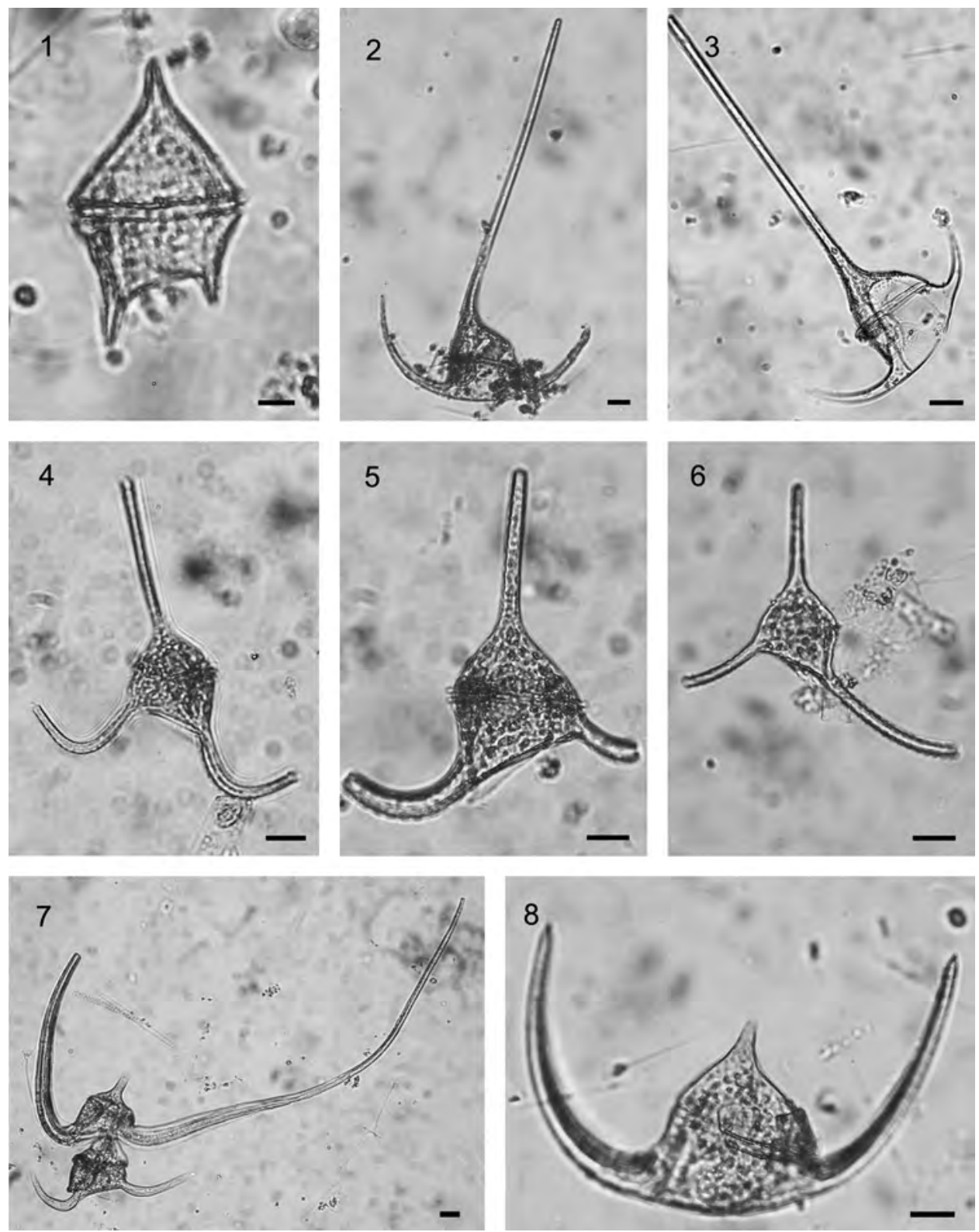

Plate 8. Recently divided cells of Ceratium species. Fig. 1. C. pentagonum var. tenerum (DV). Fig. 2. C. contortum (DV). Fig. 3. C. tripos f. tripodoides (DV). Fig. 4. C. macroceros var. gallicum (VV). Fig. 5. C. massiliense var. armatum (DV). Fig. 6. C. contortum (VV). Fig. 7. C. vultur f. vultur, two cells (DV). Fig. 8. C. tripos var. tripos (DV). Scale bars: $10 \mu \mathrm{m}$ in Fig. 1; $20 \mu \mathrm{m}$ in Fig. 2-8. 

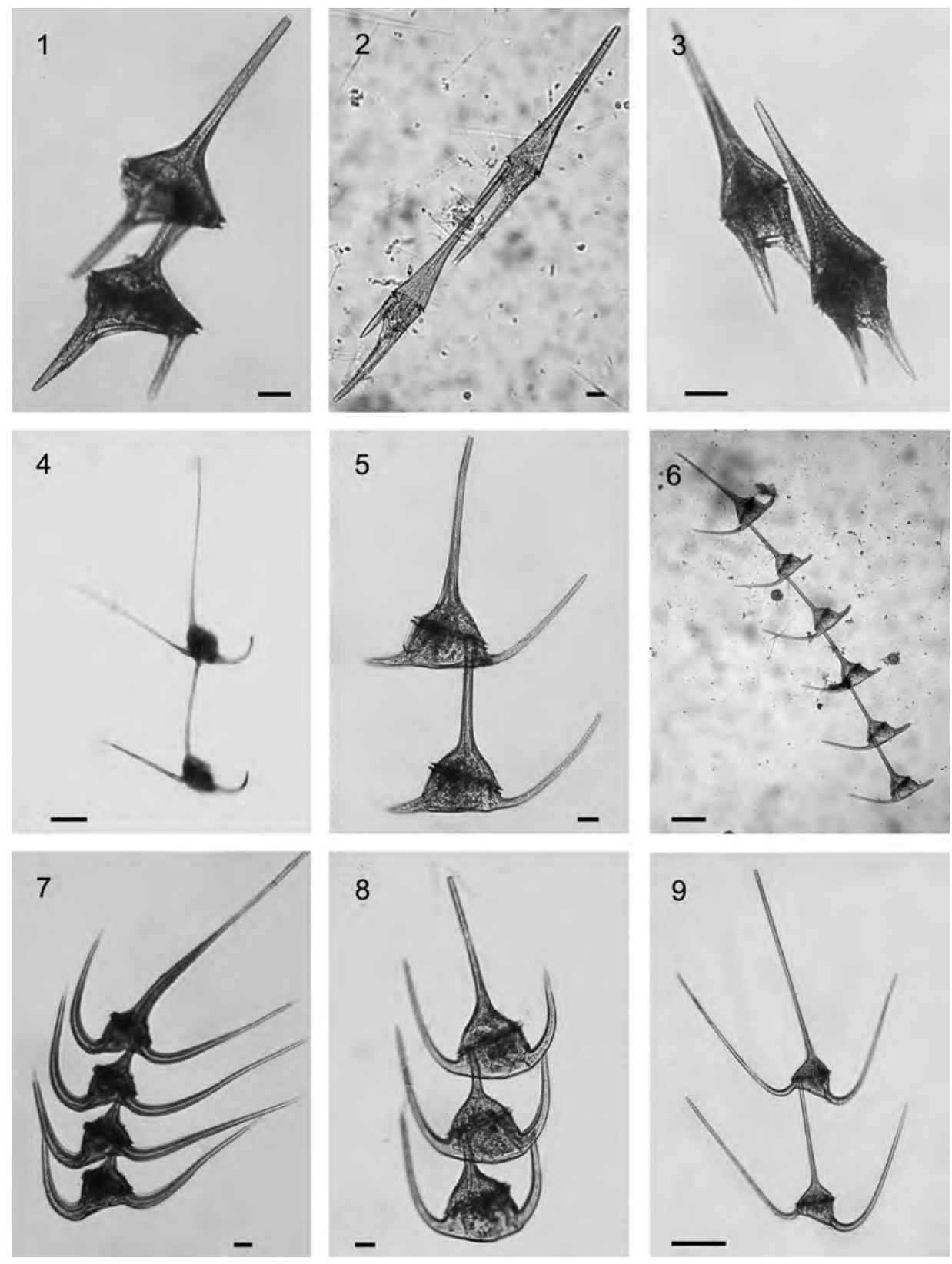

Plate 9. Colonies of Ceratium species. Fig. 1. C. candelabrum (DV). Fig. 2. C. furca var. furca (VV). Fig. 3. C. furca var. hircus (VV). Fig. 4. C. hexacanthum (VV). Fig. 5 (DV) and 6 (VV). C. dens. Fig. 7. C. vultur f. vultur (DV). Fig. 8. C. tripos (VV). Fig. 9. C. massiliense var. armatum (VV). Scale bars: $20 \mu \mathrm{m}$ in Fig. 1-3, 5, 7 and 8; $100 \mu \mathrm{m}$ in Fig. 4, 6 and 9. 


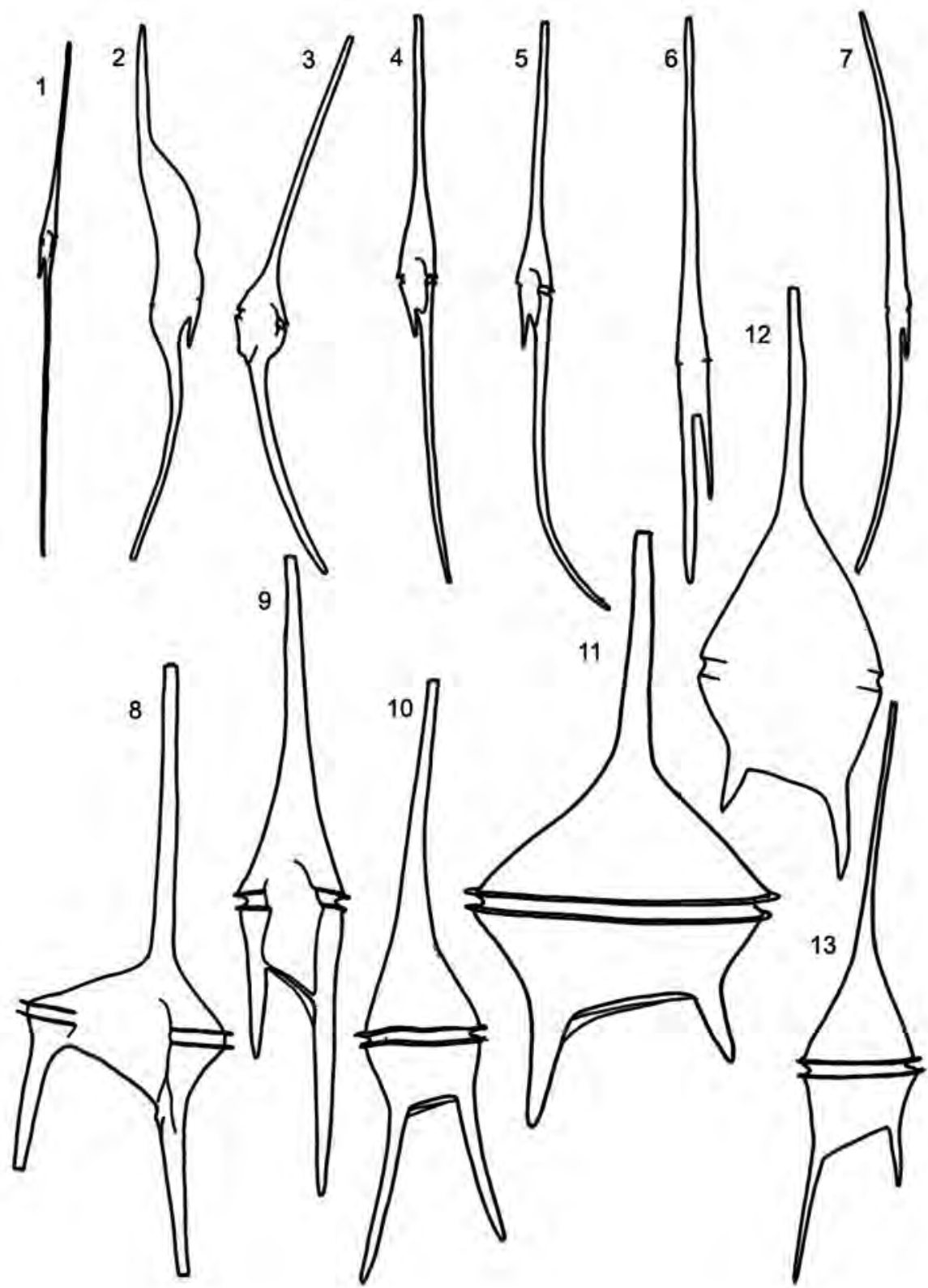

Plate 10. Fig. 1. Ceratium extensum. Fig. 2. C. geniculatum. Fig. 3. C. bigelowii. Fig. 4. C. fusus. Fig. 5. C. inflatum. Fig. 6. C. belone. Fig. 7. C. longirostrum. Fig. 8. C. candelabrum. Fig. 9. C. furca var. furca. Fig. 10. C. furca var. hircus. Fig. 11. C. pentagonum var. tenerum. Fig. 12. C. teres. Fig. 13. C. kofoidii. 
Okolodkov: Ceratium (Dinophyceae) of the National Park Sistema Arrecifal Veracruzano

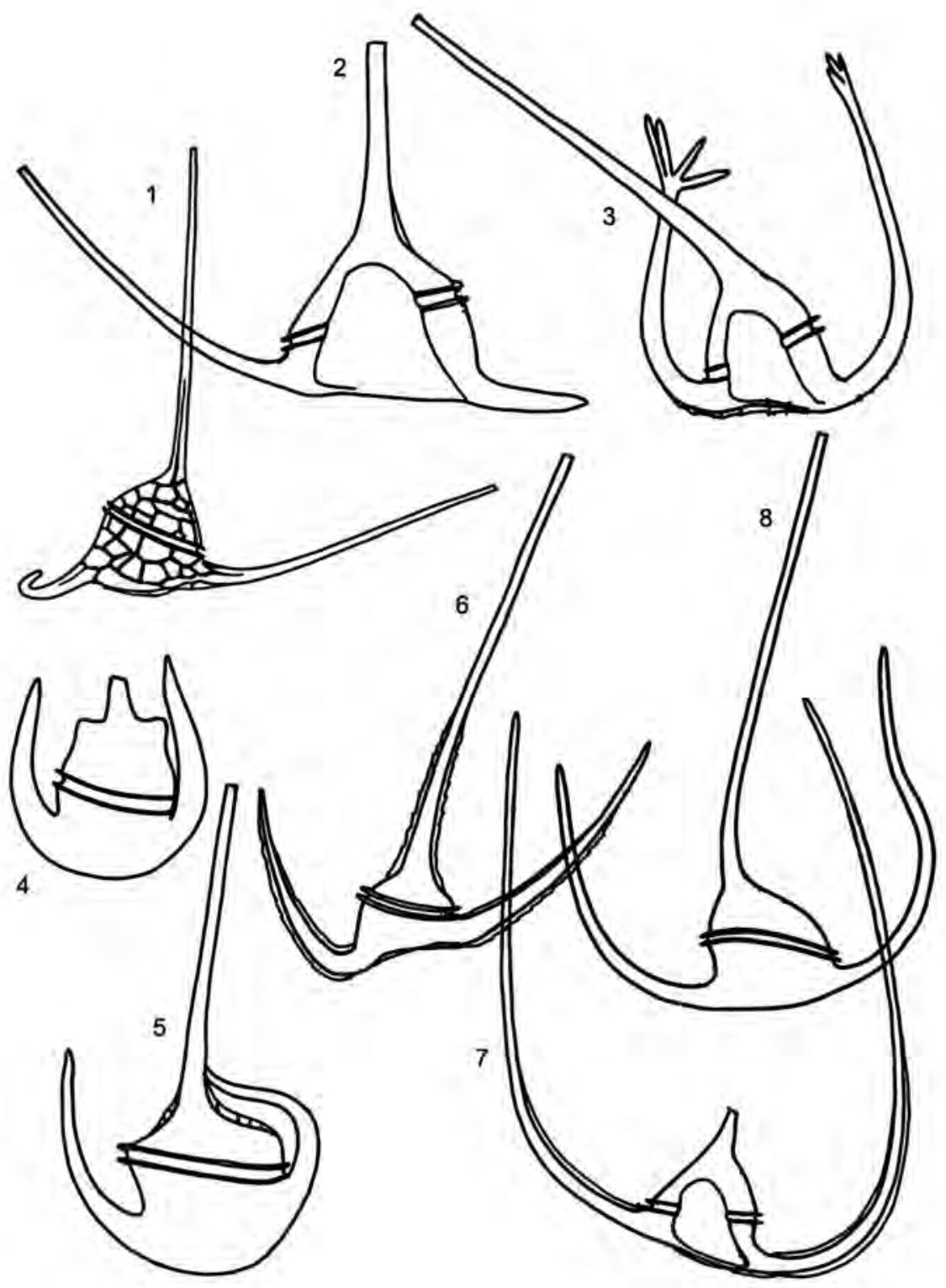

Plate 11. Fig. 1. Ceratium hexacanthum. Fig. 2. C. dens. Fig. 3. C. ranipes. Fig. 4. C. limulus. Fig. 5. C. gibberum var. dispar. Fig. 6. C. vultur f. vultur. Fig. 7. C. lunula. Fig. 8. C. contortum var. contortum. 


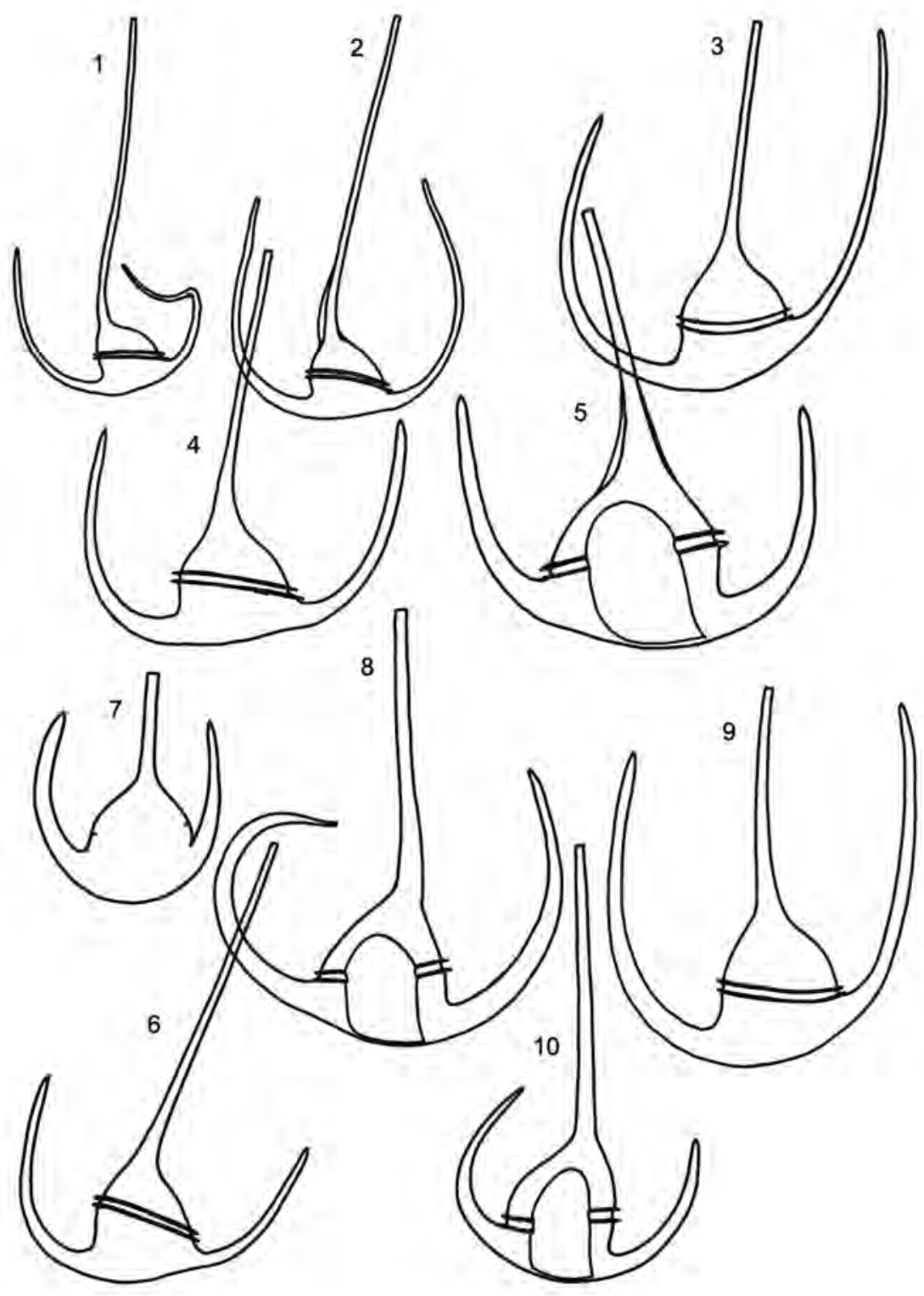

Plate 12. Fig. 1. Ceratium contortum var. saltans. Fig. 2. C. karstenii. Fig. 3. C. euarcuatum. Fig. 4. C. tripos var. tripos. Fig. 5. C. tripos var. breve. Fig. 6. C. tripos f. tripodoides. Fig. 7. C. azoricum. Fig. 8. C. arietinum var. gracilentum. Fig. 9. C. symetricum. Fig. 10. C. declinatum var. angusticornum. 


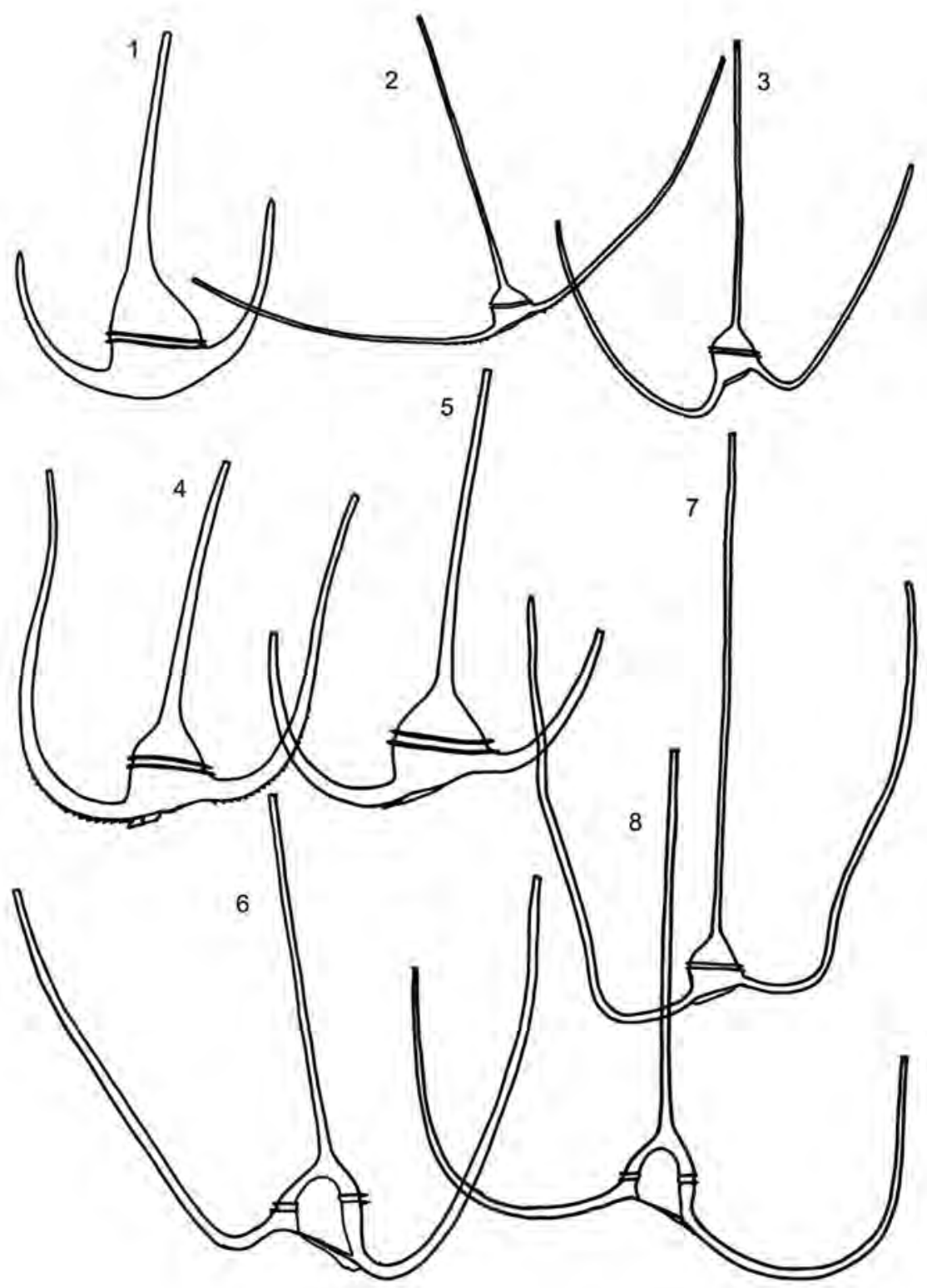

Plate 13. Fig. 1. Ceratium declinatum f. normale. Fig. 2. C. carriense. Fig. 3. C. macroceros var. gallicum. Fig. 4. C. horridum var. molle. Fig. 5. C. horridum var. buceros. Fig. 6. C. massiliense var. armatum. Fig. 7. C. contrarium. Fig. 8. C. trichoceros. 